\title{
Kaos Çağında İdeal Bir Çevre Eğitimi Politikası İçin Bazı Öneriler
}

\author{
Some Suggestions for an Ideal Environmental Education Policy in Age of Chaos
}

\author{
Ali Ekber Gülersoy ${ }^{*}$ - Hilal Yener ${ }^{* *}$ - Tuğçe Turgut ${ }^{* * *}$ - Dilay Melis Özşahin ${ }^{* * * *}$ - Deniz Anter \\ Açıkgöz
}

\begin{abstract}
Factors such as profit-oriented economic systems and population growth have brought natural resources to the point of exhaustion and have caused great damage to ecological systems. It is obvious that the basic solution to the environmental problems caused by this situation is that people have environmental awareness and show positive behavior patterns about the environment. This solution should be provided through environmental education. In this article, the development stages of environmental education, international developments, environmental education policies and practices of countries were examined, and suggestions were developed for the ideal environmental education policy. Activities on environmental education came to the fore at the global level with the international environmental conferences held in the 1970 's, and these conferences formed the basis of environmental education policies and practices of most of the countries. From the past to the present, the concept of environmental education has turned into the concept of sustainable development education. When the practices of the countries examined in the article are looking over, it has been determined that environmental education is generally given with a multidisciplinary method in formal education, out-of-class activities such as nature education are preferred, ecoschool practices are available in some countries, and special environmental education policies are designed and implemented in some countries. It has been determined that NGOs, media and environmental
\end{abstract}

\footnotetext{
* Doç.Dr., Dokuz Eylül Üniversitesi, Buca Eğitim Fakültesi, Sosyal Bilgiler Eğitimi Assoc.Prof.Dr., Dokuz Eylul University, Buca Faculty of Education, Social Studies Education ORCID 0000-0003-0338-1366

gulersoy74@gmail.com

${ }^{* *}$ Yüksek Lisans Öğrencisi, Dokuz Eylül Üniversitesi, Eğitim Bilimleri Enstitüsü, Çevre Eğitimi Anabilim Dalı M.A. Student, Dokuz Eylul University, Institute of Educational Sciences, Department of Environmental Education ORCID 0000-0003-1948-9427

hllynr@outlook.com

**** Yüksek Lisans Öğrencisi, Dokuz Eylül Üniversitesi, Eğitim Bilimleri Enstitüsü, Çevre Eğitimi Anabilim Dalı M.A. Student, Dokuz Eylul University, Institute of Educational Sciences, Department of Environmental Education ORCID 0000-0002-9743-9559

tugceturgut09@gmail.com

***** Yüksek Lisans Öğrencisi, Dokuz Eylül Üniversitesi, Eğitim Bilimleri Enstitüsü, Çevre Eğitimi Anabilim Dalı M.A. Student, Dokuz Eylul University, Institute of Educational Sciences, Department of Environmental Education ORCID 0000-0002-7043-079X

dilayy.0101@ hotmail.com

****** Yüksek Lisans Öğrencisi, Dokuz Eylül Üniversitesi, Eğitim Bilimleri Enstitüsü, Çevre Eğitimi Anabilim Dalı M.A. Student, Dokuz Eylul University, Institute of Educational Sciences, Department of Environmental Education ORCID 0000-0001-9058-0827

denizantr@gmail.com

Cite as/ Atıf: Gülersoy, A. E., Yener, H., Turgut, T., Özşahin, D. M. \& Açıkgöz, D. A. (2021). Kaos çağında ideal bir çevre eğitimi politikası için bazı öneriler. Turkish Studies, 16(5), 1495-1552. https://dx.doi.org/10.7827/TurkishStudies.52102

Received/Geliş: 14 July/Temmuz 2021

Accepted/Kabul: 25 September/Eylül 2021

Published/Yayın: 30 September/Eylül 2021

Checked by plagiarism software

CC BY-NC 4.0
} 


\section{Ali Ekber Gülersoy - Hilal Yener - Tuğçe Turgut - Dilay Melis Özşahin - Deniz Anter...}

associations support environmental education in many countries and their activities should be increased. Among the suggestions are that environmental education should be included in the scope of lifelong learning, attention should be paid to the implementation phase of the determined environmental education policies, environmental education should be included as a compulsory course in formal education, educators should be competent in the field of environmental education, and economic development should be planned and implemented in a way that does not disturb the balance of the environment.

Structured Abstract: Introduction: This period, in which ecological balance is deteriorated, and the increasing environmental problems threaten the human life on a global level, is called the Age of Chaos (Gülersoy, 2019). Factors such as economies based on continuous production and population growth have brought natural resources to the point of exhaustion; while it is accepted that the cause of the problem is human, it has been understood that the solution is also in humans (Baykal \& Baykal, 2008).

In order to minimize environmental problems, efforts should be made to protect the environment. Environmental education is one of the most effective methods of these studies, even the mainstay. The importance of environmental education, which is given in order to raise awareness of the society and to ensure permanent bahaviour, is too great to be underestimated. For this reason, first of all, the general situation of environmental education was examined and written. Then, general environmental education policies were mentioned, varios policies on environmental education were examined, the situations of these environmental education policies in some countries were investigated, documents on this subject were examined and suggestions were developed for the ideal environmental education policywhich would be determined.

\section{Purpose and Method}

This study was conducted to examine the developmental stages of environmental education, international developments, environmental education policies and practicies of countries. This article has been prepared to know the state of environmental education in our country and in other countries and to offer some suggestions in this directions in order to create an ideal environmental education policy. In the study, the descriptive survey model was preferred because the relations between environmental education and environmental policies were examined.

\section{Results}

Activities for environmental education are encountered at the regional level in the first half the 20th century. However, initiatives at the global level were started in 1970's with nature conservations and research studies. The United Nation Conference on the Human Environment held in Stockholm in 1972 was a pioneer in this regard. The United Nations Environment Program (UNEP) and International Environmental Education Program (IEEP) initiated in 1975 were established as a result of this conference. It is accepted that the Tbilisi Environmental Education Conference held in 1977 is an important initiative that includes environmental education in the education process. In the environmental education conferences held every tenth anniversary of the Tbilisi Conference, desicions were taken within the framework of the principles determined in the Tbilisi Conference. The United Nations Conference on Environment and Development was held in Nairobi in 1982 and Bruntland Report was published in 1987. In this report, 'continuous and balanced development' was highlighted. In 1992, the Rio UN Conference on Environment and Development, which argues that continuous development can be achieved through the protection of environmental values, was convened. The European Union is an organization that is interested in environmental problems and influences other countries, as well. The European Union has taken a concrete step with the Single European Act published in 1987 (Aydın \& Çamur, 2017; Tsebelis \& Kalandrakis, 1999). With the 1999 Amsterdam Treaty, all members aimed to act together with the common goal of protecting the environment. The Treaty of Nice and Lisbon are other important treaties. The European Environmental Action Programs, the first program of which was published in 1972, determine the principles of environmental policies in the European Union and are not legally binding. There are seven Environmental Action Programs organized to date.

In this article environmental education policies and environmental education practices of 31 countries, including Turkey, are mentioned. These countries; Turkey, Germany, England, Russia, Finland, Slovakia, Bulgaria, Greece, South Africa, Kenya, Malawi, Botswana, Tanzania, South Korea, Bhutan, Malaysia, Indonesia, Philippines, Hong Kong, China, Uzbekistan, Kazakhstan, Turkmenistan, Azerbaijan, Canada, USA, Ecuador, Brazil, Chile, Papua New Guinea and Australia. 
In Turkey, it can be said that environmental studies have come to the fore after the 1970's. In our country, which was affected by the Stockholm Conference, the Prime Ministry Undersecretariat for Environment was established. In the light of the Rio Conference held in 1992, the concept of sustainable development started to take place in our country. It can be said that most countries were affected by these conferences. For example, Germany was influenced by the Tbilisi Conference held in Tbilisi in 1977 and took concrete initiatives to develop an environmental education curriculum (Bolscho \& Hauenschild, 2006). South Africa was affected by the 1992 Earth Summit and Agenda 21 and this sitution provided the infrastructure for environmental education (Obol et al., 2003). Environmental education policies in Tanzania were developed based on the recommendations of the Rio Conference held in 1992. Also with impact of Rio World Summit, the Tanzania Education Institute (TIE) and the Ministry of Education and Culture (MoEC) have created a curriculum to train individuals who can solve environmental problems and serve sustainable development.

When the Development Plans, which are prepared by State Planning Organization, in Turkey are examined, it is seen that environmental regulations are included with the Third Development Plan. Environmental regulations are included in all plans after the 3rd development plan. In 1999, a cooperation protocol was signed between the Ministry of Environment and the Ministry of National Education, which included definite decisions such as introducing compulsory environmental lessons and with this protocol, it was targeted for children to raise environmental awareness (Alım, 2006). China, Slovakia and Finland are among some countries that give importance to instructor training.

\section{Discussion, Conclusion and Recommendations}

In most of the countries studied, environmental and environmental education policies have started to be formed since the 1970s, when international environmental conferences began to be held. It has been determined that there were environmental education practices in Bulgaria and Finland before the 1970s. With the formation of the concept of sustainable development, environmental education at the international level has turned into sustainable development education.

In Turkey, environmental education is included as an elective course in formal education, and environmental education is generally taught with a multidisciplinary method. The situation is the same in some countries such as Russia and China. In Finland, environmental education is compulsory in primary education. In European countries such as England, Russia, Slovakia and Bulgaria, environmental education courses are compulsory.

With the support of TUBITAK, nature education camps are organized in Turkey (Özdemir, 2007). In Finland nature trips are included in the official program. There is an eco-school application in Turkey, Germany, Finland, Slovakia, Greece, Kenya, Bhutan, Philippines, China, Kanda, Brazil and Australia. In addition, the international Eco-School Project aiming to establish schools based on environmental education is implemented in some countries such as Kenya, Turkey, Greece, Bhutan and Brazil.

In some countries, non-governmental organizations, indiviual institutes and and government support non-formal education. These countries are Turkey, UK, Malawi, Philiphines, USA, Chile. Non-governmental organizations in our country support non-formal education. The Philippines has designed and implemented policies that will raise environmental education to the level of lifelong learning.

As a result of detailed examination, environmental education course must be compulsory for environmental education policies to be influential, it should be supported with out-of-class activities such as nature education, teachers and school administrators should receive in-service training in the field of environmental education, support the work of non-governmental organizations, care about the implementation of environmental education decisions, publications on environmental education should be mandatory in media organs, cooperation with other countries should be developed, and the economic development-environment relationship should be kept in balance for environmental education policies to be effective.

Keywords: environmental education, environment policies, environmental education policies, education for sustainable development, environmental education policies of countries, the age of chaos. 
Öz: Kâr odaklı ekonomik sistemler ve nüfus artışı gibi etmenler doğal kaynakları tükenme noktasına getirmiş, ekolojik sistemlere büyük zarar vermiştir. Bu durumun sebep olduğu çevre sorunlarına yönelik temel çözümün, insanların çevre bilincine sahip olması ve çevre konusunda olumlu davranış örüntüleri göstermesi olduğu aşikârdır. Bu çözüm çevre eğitimi yoluyla sağlanmalıdır. Bu makalede çevre eğitiminin gelişim safhaları, uluslararası gelişmeler, ülkelerin çevre eğitimi politikaları ve uygulamaları incelenmiş, ideal çevre eğitimi politikasına yönelik öneriler geliştirilmiştir. Çevre eğitimine yönelik faaliyetler 1970’li yıllarda düzenlenen uluslararası çevre konferanslarıyla küresel düzeyde gündeme gelmiş, bu konferanslar ülkelerin büyük bir kısmının çevre eğitimi politikaları ve uygulamalarının temelini oluşturmuştur. Geçmişten günümüze gelindiğinde çevre eğitimi kavramı, sürdürülebilir kalkınma eğitimi kavramına dönüşmüştür. Makalede incelenen ülkelerin uygulamalarına bakıldığında çevre eğitiminin örgün eğitimde genellikle çok disiplinli yöntemle verildiği, doğa eğitimi gibi sınıf dışı etkinliklerin tercih edildiği, bazı ülkelerde eko-okul uygulamalarının mevcut olduğu, bazı ülkelerde özel çevre eğitimi politikalarının kurgulandığı ve uygulamaya konulduğu saptanmıştır. STK'nın, medyanın, çevre derneklerinin birçok ülkede çevre eğitimine destek oldukları ve etkinliklerinin artırılması gerektiği belirlenmiştir. Çevre eğitiminin yaşam boyu öğrenme kapsamına alınması gerektiği, belirlenen çevre eğitimi politikalarının uygulama aşamasına önem gösterilmesi, çevre eğitiminin örgün eğitimde zorunlu ders olarak okutulması, eğitimcilerin çevre eğitimi alanında yetkinleştirilmesi, ekonomik kalkınmanın çevrenin dengesini bozmayacak şekilde planlanması ve uygulanması öneriler arasındadır.

Anahtar Kelimeler: çevre eğitimi, çevre politikaları, çevre eğitimi politikaları, sürdürülebilir kalkınma için eğitim, ülkelerin çevre eğitimi politikaları, kaos çağı.

\section{Giriş}

Ekolojik dengenin bozulduğu, mevcut insan-çevre ilişkilerinin sürdürülemediği 21. Yüzyıl, "Kaos Çağı" olarak nitelendirilmektedir (Gülersoy, 2019). Bozulan ekolojik dengenin restorasyonu ve mevcut insan-çevre ilişkilerinin yeniden uyumlu bir hale gelmesi için ideal bir çevre eğitimi ve çevre politikaları gereklidir.

Çevreye faydalı davranışlarda bulunmaya ve bu davranışları tutum haline getirmeye çevre bilinci denilmektedir (Erten, 2012). Çevre sorunlarının çözümü, insanlarda çevre bilincinin oluşturulmasıyla, çevreyi etkileyen davranışlarında olumlu yönde değişiklikler yapmasıyla mümkündür. $\mathrm{Bu}$ sebeple bireylerin doğa, çevre sorunları, sorunların bertarafına yönelik uygulamalar hakkında bilgi sahibi olması, çevre sorunlarından dolayı sorumluluk hissedip, çözümün bir parçası olma yeterliliği göstermesi gerekmektedir. Zararı önlemeye ve telafi etmeye yönelik davranışların gösterilmesi bireyde ve toplumda çevre bilincinin geliştiğini gösterir (Erten, 2003; Erten, 2004).

İnsanlığın tanık olduğu ve etkilendiği çevre sorunları son dönemde hızlı bir şekilde etkisini artırmıştır. İklim değişikliği, etki alanını genişleten hava olayları, sıcaklık artışı gibi küresel boyutta insan hayatını olumsuz etkileyen durumlar, ülkelerin çevre sorunlarını yerel düzeyden ziyade küresel düzeyde algılamasına sebep olmuştur. Sanayileşmeye dayalı ekonomiler, hızlı nüfus artış1 gibi etkenler doğal kaynakları yok olma sürecine sokmuş, bu durum tüm dünyayı tehdit eder hale gelmiştir. Bu tehdide sebep olan insanlık, sorunun çözümünü de bulmakla yükümlüdür. Sürekli yenilenen teknolojik üretimle şekillenen günümüz insanının ileri konfor ihtiyacı, çevre üzerindeki kesintisiz tahribatın en önemli sebebidir. Sözü edilen kapsamda üretim mekanizmalarının çevreyi yıkıma uğrattığı kabul edilmiş, ekonominin doğal kaynaklara bağımlılığı sebebiyle, ekonomik ilerleme-çevre dengesini kurmayı amaçlayan sürdürülebilir kalkınma kavramı ortaya çıkmıştır (Baykal \& Baykal, 2008).

Çevre eğitimi, 1970'lerde uluslararası boyutta gündeme gelen çevre problemlerinin çözümlerinden biri olarak gösterilmeye başlanmıştır. Çözümün yine insanda olduğu bilindiği için, insanları çevre konusunda duyarlı hale getirmek, gerekli bilinci oluşturmak çevre eğitimiyle mümkündür (Özdemir, 2007). Birleşmiş Milletler'in 1977 senesinde Tiflis’te düzenlediği ilk Çevre Eğitimi Konferansı, çevre eğitiminin genel amaçlarının, ilkelerinin belirlendiği, çevre eğitimine 
dair genel bir çerçeve sunan önemli bir uluslararası etkinliktir (Özdemir, 2007; Özoğul, 1993). Çevre eğitiminin 1970'lerdeki amacı 'çevreyi korumak ve endüstrileşmenin getirdiği çevre tahribatını onarmak' iken, 1987 yılında yayınlanan Bruntland Raporu'nda sürdürülebilirlik kavramının tanımının yapılmasıyla, çevre eğitiminin amacı 'sürdürülebilir bir düzenin oluşturulmasında ve yürütülmesinde etkili bir rol oynamak' olarak değiştirilmiştir (De Haan \& Harenberg, 1999; Özdemir, 2007).

Çevre eğitimi uygulamalarında örgün eğitimde kullanılmak üzere iki seçenek belirlenmiştir: yaygın model ve tek ders modeli. Tek ders modelinde Coğrafya, Fen, Matematik gibi derslerin çevre ile ilgili kısımlarının uygun bir şekilde tek ders altında birleştirilip (Çevre Eğitimi dersi) uygulanması; yaygın modelde Fen, Sosyal, Güzel Sanatlar gibi derslerin içerisine çevre eğitimi konularının serpiştirilerek uygulanması söz konusudur (Hungerford \& Peyton, 1986; Ünal \& Dımışk1, 1998). Çevre eğitiminin gerektiğince etkili olması için erken yaşlarda başlaması gerektiği düşünülmektedir. Sınıf dışı ortamlarda, doğada istendik tutumların ve davranışların kazandırılmasına yönelik etkinlikler önerilmektedir. Örgün eğitimin ilk kademesinde çevre ile ilgili kazanımların tek bir derste değil, her bir dersin içinde gerekli ilişkilendirilmeler yapılarak verilmesi daha uygun görülmüştür (Erten, 2004).

Böyle olmasına karşın teorik olarak verilen çevre eğitimi dersinin etkililiği yeterli bulunmamış, eko-okul uygulaması şekillenmiştir. Bu okullarda müfredattaki çevre konularının günlük hayattaki karşılıklarının öğrenciler tarafından algılanıp, gerçek hayatta çevre konusunda bilinçli ve olumlu davranışlar sergileyen, ailelerini ve dolayısıyla toplumu sürdürülebilir hayata yönlendiren nesiller yetiştirmek amaçlanmaktadır. Bu kapsamda dünya çapında 30 ülkede ve 7500 okulda eko-okul projesi uygulanmıştır (Aktepe \& Girgin, 2009).

Çevre eğitiminin birçok disiplinden tema barındırması, yalnızca örgün eğitim ile değil yaygın eğitim ile de uygulanma imkânı olduğunu göstermektedir. Yaygın eğitim kapsamına giren sınıf dışı etkinliklerin çevre dernekleri, vakıflar, Milli Eğitim Bakanlığı ve bazı bakanlıklar tarafından yürütüldüğ̈̈ görülmektedir (Ozaner \& Yalçın, 2001; Özbuğutu vd., 2014). Böylesi bir ortamda yaygın eğitim uygulamalarının topluma ulaşma hacminin arttırılması yerinde bir girişim olacaktır (Özbuğutu vd., 2014).

Çevre eğitiminin etkinliğini arttırmak için hükümetlerin yeterli fon ayırması şarttır. Yeterli fon ayrılmayan ülkelerde çevre eğitiminin hiç gelişmediği ya da çok yetersiz kaldığ 1 saptanmıştır (Pagelio, 2002). Ayrılan fonun düzgün ve etkili kullanılıp kullanılmadığının takip edilmesi de hükümetlerin yükümlülüğüdür (Bakırc1 \& Artun, 2011; Çalık, 2009).

İnsanlar, doğayı ve yaşadıkları çevreyi ihtiyaçları için hammadde kaynağı ve faaliyetlerinin uygulama alanı olarak görmektedir. Endüstriyel üretim ve tüketimin hız kazandığı, insan nüfusunun önceki asırlara nazaran artış gösterdiği 20. yüzyıl büyük tahribatlara neden olan çevre sorunlarını beraberinde getirmiştir. 20. yüzyılın ikinci yarısının başında etki alanını genişleten çevre sorunları; doğal kaynakların tükenmesine ve üretimi, insan hayatını ciddi şekilde etkilemeye başlamasına yol açmıştır. Bu sonuçlar çevreye yönelik bir farkındalığın ve bilincin artmasına sebep olmuş, yerel boyutta başlayan çevre politikaları uygulamaları 1970'lerle birlikte uluslararası boyuta taşınmıştır. Çevre sorunlarının çözümüne giden ilk adım, verilen çevre eğitimi ile toplumun bilinçlendirilmesini sağlamaktır. Çevre bilincinin toplumun her kesimine aşılanması gerekliliği çevre eğitimi kavramının ortaya çıkmasına ve zaman ilerledikçe öneminin anlaşılmasıyla ulusal ve küresel düzeylerde çevre eğitimi politikalarının oluşturulmasına sebep olmuştur. Oluşturulan politikalar gerek ülkelerin kendi inisiyatifleri ile aldıkları kararlar gerekse uluslararası kuruluşların aldıkları kararlar doğrultusunda şekillenmiştir.

$\mathrm{Bu}$ çerçevede makalede çevre eğitiminin gelişim safhaları, uluslararası gelişmeler, ülkelerin çevre eğitimi politikaları ve uygulamaları incelenmiştir. 
1500 Ali Ekber Gülersoy - Hilal Yener - Tuğçe Turgut - Dilay Melis Özşahin - Deniz Anter...

\section{Amaç ve Yöntem}

Araştırmanın problem cümlesi "Kaos çağında ideal bir çevre eğitimi politikası nasıl olmalıdır?" şeklindedir. Araştırmanın alt problemleri aşağıda sıralanmıştır:

1. Dünyada ve Türkiye'de çevre eğitiminin genel durumu nasıldır?

2. Dünyada ve Türkiye'de çevre politikalarının genel durumu nasıldır? uygulanmaktadır?

3. Dünyada ve Türkiye'de çevre eğitimi politikaları ne düzeydedir ve nasıl

4. Dünyada ve Türkiye'de çevre politikaları ile ilgili belgelerde çevre eğitimine nasıl yer verilmiştir?

$\mathrm{Bu}$ araştırmanın amacı yukarıda ifade edilen sorular çerçevesinde ideal bir çevre eğitimi politikası için bazı önerilerde bulunmaktır.

Araştırmada çevre eğitimi ve çevre politikaları arasındaki ilişkiler irdelendiği için betimsel tarama modeli tercih edilmiştir. Bilindiği gibi tarama modelleri, geçmişte veya günümüzdeki herhangi bir durumu mevcut haliyle betimlemeyi amaçlayan araştırmalara uygundur (Karasar, 1999). Çalışmanın evreni, çevre eğitimi ve çevre politikalarıyla ilintili araştırmalardır.

\section{Bulgular}

Araştırma bulguları Dünyada ve Türkiye'de Çevre Eğitimine Genel Bir Bakış, Dünyada ve Türkiye'de Çevre Politikalarına Genel Bir Bakış, Dünyada ve Türkiye'de Çevre Eğitimi Politikalarına Genel Bir Bakış, Dünyada ve Türkiye'de Çevre Politikaları ile İlgili Belgelerde Çevre Eğitimi başlıkları altında incelenmiştir.

\section{Dünya'da ve Türkiye’de Çevre Eğitimine Genel Bir Bakış}

Bu bölümde dünyada ve Türkiye'de çevre eğitiminin genel durumu incelenmiştir. Çevre, canlı ve cansız varlıkların birbirleri ile olan etkileşimidir (Bakırcı \& Artun, 2011; Sungurtekin, 2001). Çevre için eğitim dünyada çevre sorunlarının engellemesinde ve bulunduğumuz çevreyi korumadaki en önemli unsurdur. Tüm hayat boyunca devam etmesi gereken çevre eğitimi bireyin kişiliğinin belirlenmeye başladığı çocukluk dönemlerinden itibaren verilmelidir (Akçay, 2006).

Çevre eğitiminin asıl hedefi; kişileri ve toplulukları çevre hakkında bilinçlendirmek, yetenek ve bilgi kazandırmak, pozitif anlamda yerleşmiş davranışlar göstermelerine destek sağlamak yanında aktif olarak çevre koruma faaliyetlerine katılımlarını sağlamaktır. Türkiye'de çevre eğitimi, genellikle kendiliğinden ilerleyen bir süreç olması nedeniyle içerisinde bulunulan eğitim seviyesi de beklenen düzeyde değildir. Toplumsal özellikler ile beraber kültürel özelliklerin de detaylı çözümlenememesi nedeniyle bilgi gereğince verilememekte, sunum tekniklerinin geride kalmış olması, halk eğitiminde olan çalışmaları ilerleten bireylerin, kurumların ve kuruluşların araç-gereçlerinin eksik kalması ve yeterli şartların temin edilememesi gibi pek çok sebepten dolayı istenilen amaçlara ulaşılamadığ 1 görülmektedir. Bunun neticesinde, insanların çevreye ve çevre problemlerine ilişkin bilinçli olma düzeyleri ve hassaslığının nispeten düşük düzeylerde olduğu tespit edilmiştir (Çolakoğlu, 2010; Demir \& Yalçın, 2014).

Çevrenin korunması hususunda kayıtsızlık bu şekilde ilerleyecek olursa büyük bir olasılıkla insanlık daha pek çok yıkım ile karşılaşacaktır. Sözü edilen çevre problemlerinin temelinde sanayileşmeyle beraber hızlanan insanoğlunun doğayı talan etmesi, doğayı kendi yararları yönünde acımasızca kullanması bulunmaktadır. Neticesinde de bu nesil ile gelecekteki nesillerin yaşamını ve aynı zamanda diğer canlıların varlıklarını tehdit etmekte olan çevre sorunları gerçeği ne yazık ki doğayı ve insanlığı tehdit etmeye devam etmektedir (Erten, 2004). 


\section{Dünya'da Çevre Ĕ̈itimi}

Çevre sorunlarının zamanla evrensel niteliklere ulaşması insanların çözüm üretmede eksik kalmalarına sebep olmaya başlamıştır. Bu gidişatın sonucunda çevrenin korunması, iyileştirilmesi ve geliştirilmesinin yalnızca aktif bir çevre eğitimi yoluyla elde edilebileceği hususunda ortaya çıkan ayırt etme, dünya genelinde çevre eğitimini temel alan çalışmaların hızla artmasına neden olmuş, 1970'li yıllardan itibaren ulusal ve uluslararası pek çok toplantıda çevre eğitimi önemle ele alınmıştır (Çelikbaş, 2016; Gülersoy vd., 2020).

21. yüzyıl topluluklarında meydana gelen değişimler, eğitime özgü beklentilerin de değişmesine neden olmuştur (Bocakova \& Kubickova, 2015; Garner, 2002; Gökmen vd., 2019).

Çevre eğitimine ilişkin faaliyetler doğa koruma ve araştırmaları biçiminde başlatılmış, çevre eğitimi için ilk tasarlama ise 1970 senesinde Dünya Günü’nde yapılmıştır. 1972 senesinde ise Stockholm'de çevre eğitimine ve çevre sorunlarının geldiği evrensel boyuta dikkat çekilen "Birleşmiş Milletler İnsan Çevresi Konferansı" yapılmış ve konferansın sonucunda 'Birleşmiş Milletler Çevre Programı (UNEP)'nın kurulması kararlaştırılmıştır. Sonrasında 1975 senesinde Stockholm Bildirisi esas alınarak Birleşmiş Milletler Çevre Programı kapsamında 'Uluslararası Çevre Eğitimi Programı' (IEEP) başlatılmıştır. 1977 senesinde Tiflis’te gerçekleştirilen çevre eğitimiyle ilgili konferansta çevre eğitiminin yalnızca uluslararası iş birliği ile mümkün olabileceği belirtilerek UNESCO ve UNEP'in atılımlarının uluslararası alanda yayılmasının gerekliliği uygun bulunmuştur. Tiflis Konferansı Bildirgesi ve Önerileri, çevre eğitiminin eğitim sürecine dâhil edilmesinde bir dönüm noktası olarak kabul görmüştür. Çünkü sözü edilen belgelerde çevre eğitiminin ulusal ve uluslararası seviyede olması, amaçların ve pedagojik esasların açıkça gösterilmesi açısından önemlidir (Ertürk, 1975; Gülersoy vd., 2020; Ünal \& Dımışk1, 1999).

Sürdürülebilirlik ve eğitim ilişkisinin bağdaşması sürecinde 5 önemli adım görülmektedir:

- 1977 Tiflis Bildirgesi,

- 1992 Gündem 21,

- 2002 Birleşmiş Milletler Sürdürülebilir Kalkınma İçin Eğitimin On Yılı Hedefleri

(2005-2014),

- 2005 BM Avrupa Ekonomik Konseyi (UNECE),

- 2013 Sürdürülebilir Kalkınma İçin Eğitim Stratejisi, UNESCO Küresel Eylem Program1 (2015-2019) (Gökmen vd., 2019; Michelson \& Ficher, 2017).

Yukarıda belirtilen adımlarda görüldüğü üzere 1970’li senelerde başlayan çevre sorunlarına karşı çözüm arayışları günümüzde de devam etmektedir. Yapılan çalışmaların ışığında çevre sorunlarına alternatif çözüm önerileri yine çevre eğitiminden geçmektedir. Bu sebeple çevre sorunlarına karşı geliştirilen çözüm önerileri çevre eğitimi ile iç içedir. Çevre eğitimi ve çevre sorunları açısından önemli olan bu beş adım, çevre sorunlarının küresel bir boyuta ulaştığını ve bunun için önlemler alınması gerektiğini vurgulamaktadır. Topluma verilen çevre eğitimi bu süreçte kilit konumundadır. Sorunların içerisinde başkahraman rolünü oynayan insan yine bu sorunlara karşı çözümün ta kendisidir.

\section{Türkiye'de Çevre Eğitimi}

1982 Anayasası'nın 56. Maddesinde "Çevreyi geliştirmek, çevre sağlı̆̆ını korumalı çevrenin kirlenmesini önlemek devletin ve vatandaşların görevidir" (TBMM, 2015) ifadesi bulunmaktadır. Anayasanın bu maddesinde tüm halkın sağlıkı bir çevre içinde yaşama hakkına sahip olduğu belirtilmiştir. Çevrenin korunması anayasa maddesinde belirtildiği gibi sadece devletin değil tüm insanların da görevidir. Bu madde aslında verilen çevre eğitiminin hedeflerine ulaşmasında önemli bir etken olarak görünmektedir (Gülersoy vd., 2020). Geçmiş yıllara nazaran 
son yıllarda Türkiye'de öncelikle Çevre ve Şehircilik Bakanlığı'nın önderliğinde Milli Eğitim Bakanlığı ve Aile, Çalışma ve Sosyal Hizmetler Bakanlığı gibi bakanlıkların takibi ile çeşitli kuruluşlar ve sivil toplum örgütlerinin de işbirliği ile örgün ve yaygın eğitimde çevre eğitim uygulamaları görülmektedir. Örgün öğretim içerisinde yer alan öğretim programları incelendiğinde ise çevre eğitimine ilişkin konuların farklı derslerin programları içinde verilmeye çalışıldığı görülmektedir (Bulut, 2015; Gülersoy vd., 2020; Kız1l, 2012).

\section{1. İlkokul, Ortaokul ve Lise Öğretim Programlarında (Örgün Eğitimde) Çevre Eğitimi}

Ülkemizde eğitim, örgün ve yaygın olmak üzere iki ayrı başlık altında sürdürülmektedir. Milli Eğitim Bakanlığı'nca uygulanmakta olan ilköğretim ile ortaöğretim öğretim programlarına bakıldığında ortaokullarda 7. ve 8. sınıflara ait seçmeli ders konumundaki Çevre Eğitimi (2 saat) dersi dışında çevre eğitimi adı altında başka bir dersin olmadığı görülmektedir. Örgün eğitimde çevre eğitimi konuları; Hayat Bilgisi, Sosyal Bilgiler, Coğrafya, Fen Bilimleri / Fen ve Teknoloji, Biyoloji, Kimya, Sağlık Bilgisi ve Trafik Kültürü derslerinde ünite temelli yer almaktadır. Bahsedilen derslerin öğretim programlarında çevre ile ilgili kazanımlar görülmektedir (Demir \& Yalçın, 2014; Gülersoy vd., 2020; Milli Eğitim Bakanlığı, 2018). Ortaokul ders programında (7. ve 8. Sınıflar) seçmeli olarak yer alan 'Çevre Eğitimi' dersi, ne yazık ki öğrenciler tarafından tercih edilmemektedir.

\subsection{Yükseköğretim Programlarında Çevre Ĕ̆itimi}

Yükseköğretim programlarında eğitim fakültelerinde okul öncesi, sınıf, sosyal bilgiler, fen bilgisi, coğrafya ve biyoloji öğretmenliği anabilim dallarında çevre eğitimi dersinin genellikle seçmeli olarak okutulduğu görülmektedir. Bütün eğitim aşamalarında rastlanılan kavram yanılgıları, çevre eğitiminin beklenilen seviyede aktif olmadığını ve bu dersin ezberci öğretim yöntemleriyle işlenmesinin yanlış olduğunu ifade etmektedir (Haktanır \& Çabuk, 2000; Özkan vd., 2001; Şahin vd., 2004; Yücel \& Morgil, 1998; Webb \& Boltt, 1990). Bu durum çevre eğitimini verecek olan öğretmen adaylarının yükseköğretim aşamasında daha iyi bir eğitim alması gerektiğini ön plana çıkarmaktadır. Çevreye karşı hassas ve bilinç düzeyi yüksek olan öğretmenler, çevre hususunda öğrencilere gerekli olan bilincin ve sorumluluğun kazandırılmasında etkin rol oynayabilirler. Buna ilave olarak dersin etkililiğini yükseltmek için öğrencinin daha aktif olmasını sağlayacak öğretim yaklaşımlarının kullanılması zorunlu olmalıdır (Şahin vd., 2004).

\section{Dünyada ve Türkiye’de Çevre Politikalarına Genel Bir Bakış}

Genel olarak çevre politikaları bir ülkenin çevre sorunlarına karşı alacağı tedbirleri ve bu konulardaki hedeflerini belirtir. Çevre politikaları, çevre sorunları için kabul edilen ilkelerin ve kuralların tamamıdır (Aydın \& Çamur, 2017; Budak, 2000). Bir başka tanıma göre ise çevre politikaları bir ülkenin çevre konusundaki tercihlerini belirten ve bu konuda önlerine koydukları hedefleri gösteren politikalardır (Keleş \& Hamamc1, 2002).

\footnotetext{
"Çevre politikalarının belirlenmesinin ve uygulanmasının temel koşulu, tanılamadır (teşhis). Bu aşamada, toplumun çevreye vermekte olduğu değerin ölçülmesi önem taşır. Halkın değer yargıları, politikaların yöneldiği hedeflerin belirlenmesi için birer araçtır. İkinci aşamada ise, türlü müdahale (karışma, düzenleme) yöntemlerinin incelenmesi, karşılaştırılması ve aralarından en uygun görünenlerin seçilmesi gelir. Son aşama ise, genel olarak belirlenen politikaların, karar mekanizması içinde uygulanmasının sağlanmasıdır" (Keleş \& Hamamc1, 2002).
}

Çevre politikalarının ortaya çıkmasının sebebi 20. yy'ın ikinci yarısı itibari ile artan çevre sorunlarıdır. $\mathrm{Bu}$ sorunlar doğanın kendini yenileyememesi ve kaynakların tükenmesiyle baş göstermiştir (Arat vd., 2002; Terzi, 2017). Bu doğrultuda ülkeler kendi çevre politikalarını oluşturmaya başlamış olsalar dahi ortak anlayış, insanlara sağlıklı bir çevre bırakma olmuştur. Çevre sorunları gibi küresel ölçekte bir sorun ancak herkesin çabası ile önlenebileceği için 
üretilecek çevre politikalarının uluslararası düzeyde olması gerekmektedir (Terzi, 2017; Toprak, 2003).

Özellikle II. Dünya Savaşı sonrası savaşın yarattığı zararla çevre koruma konusunda daha ciddi adımlar atılmıştır. 1960'lardan sonra başlayan yoğun araştırmalar sonucunda çevresel sorunlarının etki alanının ve sonuçlarının geri dönülemez boyutlara ulaştığı görülmüştür. Bu tarihlerden itibaren tüm dünyayı kapsayıcı korumacı bir anlayış benimsenmiştir. Bu sebeple söz konusu tarihten itibaren uluslararası düzeyde çevre koruma ve çevre ile ilgili toplantılar yapılmıştır. Birleșmiş Milletler bu konuya uluslararası düzeyde yaklaşan ilk kurumdur. Sözü edilen toplantılarda mevcut sorunlar ortaya konulmuş ve kaynakların kullanımıyla ilgili önlemler, öneriler tartışılmış, uygulanması gereken politikalar tespit edilmiştir (Yıldız vd., 2005).

\section{Birleşmiş Milletler ve Çevre Politikaları}

Stockholm Birleşmiş Milletler İnsan-Çevresi Konferansı'nda (1972) "Tek Bir Dünya" görüşü ortaya çıkmış ve bu görüş katılan tüm ülkelerce benimsenmiştir. 1972 y1lındaki bu toplantıya Türkiye dâhil 113 ülkeden temsilci katılmıştır. Bu konferans sonucunda ortak amaçla hareket etme gerçeği kabul edilmiş, tüm insanlık ve gelecek nesiller için, bütün hükümetler ve insanlar çevre koruma ve geliştirme adına çaba göstermeye davet edilmiş ve 5 Haziran günü "Dünya Çevre Koruma" günü olarak ilan edilmiştir. Sonrasında "Nairobi Birleşmiş Milletler Çevre ve Kalkınma Konferansı (1982)" yapılmış ve 1987'de "Ortak Geleceğimiz" başlıklı Brundtland Raporu yayımlanmıştır. Bu rapor çevre korumaya ayrı bir anlam kazandırmıştır. Çevreye zarar vermeden kalkınmanın yalnızca "sürekli ve dengeli kalkınma" yoluyla olacağı vurgulanmıștır. 1992 yılındaki "Rio BM Çevre ve Kalkınma Konferansı (Rio Dünya Zirvesi)"ında ise sürekli kalkınmanın ancak çevresel değerlerin korunmasıyla mümkün olduğu savunulmuştur. Ayrıca alternatif doğal kaynaklar bulunamadığı sürece bu kalkınmanın durabileceği vurgulanmıştır. Tüketilen ve üretilen doğal kaynaklar arasında denge kurulması gerekliliği tüm ülkelerce kabul edilmiştir. 1998 yılında Birleşmiş Milletler tarafından 2002 yılının "Dağlar Y1lı" olarak kutlanılması kabul edilmiş ve 2002 yılının 29 Ekim-1 Kasım tarihlerinde Bişkek'te "Küresel Dağlar Zirvesi” toplantısı yapılmıştır. Bu toplantının amacı ise dağlık bölgelerde sürdürülebilir kalkınmayı güçlendirmek ve bölge halkının refah seviyesinin arttırmak olmuştur. 2002'de ise Johannesburg'da "Birleşmiş Milletler Sürdürülebilir Kalkınma Konferansı" düzenlenmiştir. Söz konusu konferansta küresel iklim değişikliği, hızlı nüfus artışı, beslenme, sağlık, su kıtlığı, çevre kirlenmesi vb. tartışılmıştır (Yıldız vd., 2005). Rio BM Çevre ve Kalkınma Konferansı'ndan 20 yıl sonra 2012 y1lı haziran ayında Rio+20 Konferansı'nda BM üyesi ülkeler tekrar bir araya gelmiştir. $\mathrm{Bu}$ konferans sonucunda Sürdürülebilir Kalkınmanın Hedefleri'nin oluşturulmasına karar verilmiştir (Terzi, 2017; Sustainable Development Knowledge Partnership, 2021).

\section{Avrupa Birliği ve Çevre Politikaları}

Avrupa Birliği çevre sorunlarıyla mücadele eden önemli kuruluşlara öncülük etmektedir. Birliğe üye olan ve olmayan ülkelerin çevre politikaları açısından birlik önemli bir noktadadır. Çevre konusunda sahip olduğu standartlar ile diğer devletleri etkilemektedir. Bu anlamda birlik aslında standartları belirleyen ve sürdürülebilir kalkınma konusunda diğer ülkeleri bir araya getiren bir güçtür. Avrupa Birliği'nin kurucusu olan Roma Antlaşması'nda çevre konusuna doğrudan yer verilmemiştir. $\mathrm{Bu}$ açıdan bakıldığında birliğin çevre politikaları henüz çok gençtir. Özellikle 1960'lı yıllardan sonra varlığını iyice hissettiren çevre sorunları birlik ülkelerini etkilemiştir. Birliğin ilgilendiği tarım, tek pazar, ulaştırma, sanayi gibi konular, çevresel konular ile bağlantılıdır. $\mathrm{Bu}$ sebeplere bağlı olarak birlik 1970'li yıllardan sonra çevre politikalarını geliştirmeye yönelmiştir. Ancak 1987 yllındaki Avrupa Tek Senedi'ne kadar somut bir adım atılmamıştır (Aydın \& Çamur, 2017; Tsebelis \& Kalandrakis, 1999). Senedin 130R, 130S ve 130T maddelerinde doğal kaynakların ihtiyatlı kullanılması, çevre sağlı̆̆ ve kalitesinin korunması, insan sağlı̆̆ının korunması gibi konularda üretilecek olan politikaların avantajları ve dezavantajlarına 
değinilmiştir (Aydın \& Çamur, 2017; Lavrysen \& De Vos, 2002). Avrupa Tek Senedi, o tarihe kadar somut anlamda atılan ilk adım olması sebebiyle önemli bir yer tutmaktadır (Aydın \& Çamur, 2017). 1992'de imzalanan Maastricht Antlaşması ile Avrupa Topluluğu'nun adı Avrupa Birliği olarak değiştirilmiştir. Birlik dâhilindeki çevre politikaları daha geniş olarak ele alınmış ve Avrupa Tek Senedi ile 130R, 130S ve 130T maddeleri düzenlenmiştir. İlk kez bu antlaşma ile çevre korunması Avrupa Birliği hedefleri arasına girmiş ve çevre koruma politikaları sürdürülebilirlik ilkesi çerçevesinde ele alınmıştır (Görmez, 2007; Terzi, 2017). 1997'de imzalanan ve 1999 yılında yürürlüğe girebilen Amsterdam Antlaşması tüm üyelerin çevre koruma hususunda beraber hareketini amaçlamıştır. Özellikle antlaşmanın 6. maddesi gereğince çevreyi koruma ve sürdürülebilir kalkınmanın teşvik edilmesi için Avrupa Birliği’nin politika ve önlemler tanımlamasından, bunları birleştirici hale getirilmesinin gerekliliğinden söz edilmiştir (Sarıkaya, 2004; Terzi, 2017). Bu anlaşma ile genel politikada bir değişiklik olmasa bile çevre koruma konusundaki etkinin arttırılması amaçlanmıştır (Terzi, 2017). Nice Antlaşması 2001 yılında imzalanmış ve bu çerçevede çevreyle alakalı düzenlemeler ön plana çıkarılmış, antlaşmada imzası bulunan ülkelerin çözümde etkin rol oynamaları kararı alınmıştır (Duru, 2007; Terzi, 2017). 2007'de imzalanan ve 2009'da yürürlüğe giren Lizbon Antlaşması (Aydın \& Çamur, 2017; Kaygısız, 2012) Avrupa Birliği’nin çevre politikasının temellerini oluşturan ilkeleri bir bütün olarak göstermektedir (Aydın \& Çamur, 2017; Duru, 2007). Avrupa Birliği’nin anayasası olarak görülen antlaşma birliğin çevre koruma konusunda atacağı adımları genişletmiş̧ir. Antlaşmanın çevre konusundaki maddesinde çevre politikası; çevresel kalitenin geliştirilmesi, korunması ve sürdürülmesi, kaynakların dikkatli ve elverişli olarak kullanılması, toplum sağlı̆̆ının güvende olması, bölgesel ve uluslararası seviyede yaşanılan çevre sorunlarının yok edilmesini sağlayacak şekilde oluşturulmuştur (Aydın \& Çamur, 2017).

Avrupa Birliği çevre politikasının temel amaçları; kirliliği ortadan kaldırmak ve engellemek, doğal kaynakların kullanımının ekolojik dengeye daha fazla zarar vermesini önlemektir. Birliğin çevre politikası kalkınmayı göz önüne alan, aynı zamanda çalışma şartlarının iyileştirilmesi, kent planlamaları, toprak kullanımı gibi konuları içerir. Avrupa Birliği, çevre politikalarında kendisine üye devletler dışındaki devletler ve uluslararası örgütlerle çevre konusunda ortak çözümler üretmeyi hedef olarak saptamıştır (Bayram vd., 2011; Budak, 2000).

\section{Avrupa Birliği Çevre Eylem Programlart}

Politik çalışmalardan biri olan Çevre Eylem Programları Avrupa Birliği içerisinde takip edilecek çevre politikalarının ilkelerini belirler, aynı zamanda yapılacak olan yasal düzenlemeler konusunda rehberlik görevi görür (Aydın \& Çamur, 2017; Duru, 2007; Toprak, 2003). Avrupa Komisyonu tarafindan oluşturulan Çevre Eylem Programları hukuksal bağlayıcıllğı olmayan çalışmalardır (Aydın \& Çamur, 2017; Durmaz, 2004). Çevre Eylem Programları AB'ye üye olan ülkelere kılavuzluk etmek için oluşturulmuştur (Aydın \& Çamur, 2017). Avrupa Birliği Çevre Eylem Programları çok eski bir tarihe dayanmamaktadır. İlk program 1972 yılında hazırlanmıştır. Bu tarihten itibaren 4-5 yıllık dönemler halinde programlar hazırlanmıştır (Aydın \& Çamur, 2017; Bulut, 2008). Günümüze kadar yedi program uygulanmıştır.

Birinci Çevre Eylem Programı 1973 ve 1976 yılları arasını kapsamaktadır (Aydın \& Çamur, 2017; Hey, 2005). Bu program ilk çevre eylem programıdır ve Stockholm Konferansı'nda belirlenen ilkelerden etkilenmiştir (Duru, 2007). Bu program dâhilinde birlik önüne üç hedef koymuştur. Bunlar; gürültü ve kirlilik kaynaklarının azaltılması ve önlenmesi, çevreyi ve yaşam koşullarının iyileştirilmesi, uluslararası örgütler ile işbirliğinin geliştirilmesidir (Aydın \& Çamur, 2017; Budak, 2000). İlk program olmasından dolayı diğer programlara nispeten kapsamı daha dardır, fakat yine de önemli adımlar atılmıştır.

İkinci Çevre Eylem Programı 1978 ve 1982 yılları arasını kapsamaktadır. Bu program 1. Çevre Eylem Programı'nın genişletilmiş halidir. İlk kez bu programda Çevresel Etki 
Değerlendirilmesi (ÇED) gündeme gelmiştir. Bu programda temel öncelik su ve hava kirliliğinin önlenmesidir (Bayram vd., 2011; Türkiye Çevre Vakfi, 2001).

Yapılan iki programdan sonra "kirleten öder, herhangi bir faaliyetin çevreye etkilerinin göz önüne alınması, çevresel eylemlerin en uygun ve en elverişli şekilde ele alınması, kirlenmenin önlenmesi, meydana geldikten sonra ortadan kaldırılmaya çalışılmasından daha etkilidir" ilkeleri belirlenmiştir (Bayram vd., 2011).

Üçüncü Çevre Eylem Programı 1982 ile 1986 seneleri arasını kapsamaktadır. Bu programda birinci ve ikinci programda yer almayan ve genel konular ele alınmıştır. Bunların arasında ÇED prosedürünün hazırlanması, çevre politikalarının diğer politikalara uyumlu hale getirilmesi ve bazı önemli yerlere çevresel konumu gereğince öncelik verilmesi vardır (Bayram vd., 2011; Egeli, 1996). Ayrıca bu programda, üye ülkelerin kabul ettikleri ilkeleri uygulamaya koymaları şart koşulmuştur (Duru, 2007). Bu sayıda belirlenen ilkelerin hayata geçirilmesi amaçlanmıştır. Bir sorun meydana gelmeden engellenmesi amacıyla uygulanan çözüm yolları hem ekonomik açıdan hem de çevre açısından daha elverişlidir. Bu sebeple önleyici politikalar dikkat çekmektedir. Sanayide daha az kirletici kaynakların kullanılması, yenilenebilir enerji kaynaklarının kullanılıp fosillerden çıkan zararlıların azaltılmaya çalışılması, geri dönüştürülebilen atıkların ön planda tutulması bu plana yöneliktir (Yaman \& Gül, 2018).

Dördüncü Çevre Eylem Programı 1987 ve 1992 yılları arasını kapsamaktadır. Bu programın en önemlisi, imzalanan Avrupa Tek Senedi sonrasında hazırlanan ilk çevre eylem programıdır (Aydın \& Çamur, 2017; Ulukent, 2010). Ayrıca bu program bu senedin belirlediği politikalar doğrultusunda hazırlanmıştır. Diğer programlara ek olarak su kalitesinin kontrolü, kimyasal maddelerin denetlenmesi gibi ilkelere de yer verilmiştir. Ayrıca 1987 yılı Avrupa Çevre Yılı olarak ilan edilmiştir (Yaman \& Gül, 2018). Bu programda özellikle tarım sektörünün çevreye verdiği zararlar nasıl dengelenebilir arayışına gidilmiştir. Kirliliğin ortaya çıkmadan önce önlenmesinin maddi anlamda ilerleyen zamanlarda getireceği faydalara dikkat çekilmiştir. Bu program ilk kez çevre sorunlarına yönelik finansman kaynaklarını devreye sokmuştur (Aydın \& Çamur, 2017; Çokgezen, 2007).

Beşinci Çevre Eylem Programı 1993 ve 2000 yılları arasını kapsamaktadır. Bu program "Sürdürülebilirliğe Doğru" olarak adlandırılmıştır (Aydın \& Çamur, 2017; Popeanga, 2013). Bu program Rio Konferans1 (1992), Maastrich Anlaşmas1 ve Gündem 21'den etkilenerek hazırlanmıștır. İklim değişikliği, kentsel çevrenin tahribi, hava kirliliği, doğal kaynakların gittikçe ortadan kalkması ve biyolojik çeşitlilikteki azalma, sahil alanları ile atıklar gibi konulara öncelik verilmiştir (Duru, 2007). Kirleten öder ve ihtiyatlılık ilkesinin uygulanması ve sorumluluğun paylaştırılması bu programın ilkelerindendir. Bu programın en temel amacı, topluluk içerisindeki büyümeyi sürdürülebilir kalkınmaya dönüştürebilmektir (Aydın \& Çamur, 2017; Sarıkaya, 2004).

Altıncı Çevre Eylem Programı 2002 ve 2012 seneleri arasını kapsamaktadır. Bu program "Bizim Seçimimiz Bizim Geleceğimiz" başlığı altında kabul edilmiştir. Bu programın üzerinde durduğu konu çevre hukukunun üye ülkeler tarafından tam olarak uygulanması ve çevresel ilkelerin ve çevresel politikaların tam uyumununun üyelerce tümüyle onaylanmasıdır (Aydın \& Çamur, 2017; Popeanga, 2013). Bu program önceki programlardaki temel ilkeler üzerine kuruludur ve küresel boyuttaki çevre problemlerini daha kapsamlı bir şekilde irdelemiştir (Aydın \& Çamur, 2017; Duru, 2007). İklim değişikliği, doğa ve biyolojik çeşitlilik, doğal kaynaklar ve atık, çevre ve sağlık yaşam kalitesi gibi başlıklar ele alınan bazı konulardır (Yaman \& Gül, 2018). 
1506 Ali Ekber Gülersoy - Hilal Yener - Tuğçe Turgut - Dilay Melis Özşahin - Deniz Anter...

"Gezegenin Sınırları İçinde, Daha İyi Yaşamak" sloganıyla yürürlüğe giren Yedinci Çevre Eylem Programı 2014 ve 2020 yılları arasını kapsamaktadır' (Aydın \& Çamur, 2017; Kıvılcım, 2014). Bu programda dokuz öncelikli alandan söz edilmektedir. Bu alanlar; birlik sermayesini korumak ve geliştirmek, Avrupa Birliği kaynaklarını etkili kullanmak ve bu kaynakları çevreci, düşük karbona dayalı bir ortama dönüştürmek, çevre sorunlarından kaynaklı vatandaşların sağlık ve refahını bu sorunların oluşturacağı risklerden korumak, bilgilendirme ağı geliştirilerek bu ağ ile daha iyi bilgi verilmesinin sağlanması, mevzuatın daha iyi kullanımının sağlanması, çevre politikası kapsamında daha mantıklı ve geniş çaplı yatırımların yapılmasını gerçekleştirmek, çevre politikalarından doğan düşünce ve şartların diğer politikalarla bütünleşmesini sağlamak, üye ülkelerin daha da sürdürülebilir duruma getirilmesini sağlamak ve son olarak birliğin çevre sorunlarına karşı daha etkili bir tutum almasını sağlamaktır (Aydın \& Çamur, 2017). Bu programda sürdürülebilirliğin ön plana çıkmasıyla birlikte gelişmelerin yetersiz olduğu vurgulanmıştır. $\mathrm{Bu}$ yetersizliğin teknolojideki ilerlemelerle azaltılabileceği belirtilmiştir (Yaman \& Gül, 2018). Söz konusu program sonucunda hava, su ve toprak kirliliğinde kayda değer azalmalar görülmüştür. Birçok tehlikeli kimyasalların kullanımı kısıtlanmıştır (Aydın \& Çamur, 2017).

Çevre Eylem Programları, yalnızca AB'ye üye olan ülkeler tarafindan uygulansa da aday ülkelere ve diğer ülkelere de örnek olmuştur (Aydın \& Çamur, 2017). Ayrıca Çevre Eylem Programları'nın oluşturuldukları yıllardaki konferans ve antlaşma gibi unsurlardan etkilendikleri gözlenmektedir.

\section{4. Çevre Politikasının Temel Ilkeleri}

Çevre politikasının temelleri ihtiyatlılık, sürdürülebilir kalkınma, kirleten öder, katılım, önleme ve entegrasyon ilkeleridir. Eğer çevre korumasına dair bir politika üretiliyorsa bu ilkelerin göz önünde bulundurulması gereklidir (Budak, 2021).

İhtiyatlılık ilkesi bir işin çevre konusunda olumsuz sonuçlar doğuracağına yönelik yoğun şüpheler bulunuyorsa ortaya çıkar. Bu ilkenin temelinde yapılacak iş sonucunda ortaya çıkmasından şüphelenilen olumsuz sonuçlar tezahür etmeden önlem almak vardır. Sürdürülebilir kalkınma ilkesi geleneksel kalkınma anlayışının aksine doğa ile uyum içerisinde bir kalkınmayı savunur. "Ortak Geleceğimiz" raporunda derinlemesine ele alınmıştır. Devamlı ve istikrarlı bir kalkınmanın zorunluluk olduğu, yalnızca belirtilen kalkınma ile gelecek nesillerin yoksunlukları konusundan taviz verilmemesi savunulmuştur. Sürdürülebilir kalkınma ilkesi ekolojik, ekonomik ve sosyal kalkınmanın birbirinden bağımsız olmadığını göstermiştir. Kirleten öder ilkesi ise temel olarak kirliliği yaratan taraf tarafından kirlilik ile mücadelenin karşllığ olan bedelin ödetilmesidir. $\mathrm{Bu}$ ilke karşımıza çevre vergileri, kirlilik ücretleri gibi yöntemlerle çıkmaktadır. Katılım ilkesi ile toplumu oluşturan bireylerin çevresel yönetim süreçlerine dâhil olmaları bu süreçte aktif rol oynamaları ve bunun sonucunda kendi yaşadıkları alanlar üzerindeki değişikliklerde sürece katılımları ve yön vermeleri amaçlanmıştır. $\mathrm{Bu}$ ilke bireylerin süreç içerisindeki etkin rol oynamalarının dışında, süreç içerisinde karar alınması ve bu kararların uygulanması gibi süreçlerde denetim imkânı sunmakla birlikte, devlet politikalarının da şeffaflığını arttırmaktadır. Önleme ilkesi ile çevre sorunları oluşmadan önce tedbirler alınması amaçlanmıştır. Bu ilkenin temelinde çevre sorunları oluşmadan önce alınan tedbirlerin, sorunlar ortaya çıktıktan sonra alınacak tedbirlerden daha akılcı ve ekonomik olması fikri vardır (Budak, 2021). Entegrasyon ilkesi birliğe ait diğer politikaların içerisine çevre politikaların entegre edilmesini aynı zamanda üretilecek politikaların çevre korunmasını önemsemesi gerektiğini belirtmektedir (Bayram vd., 2011).

\footnotetext{
${ }^{1}$ Avrupa Komisyonu 14 Ekim 2020 tarihinde 8. Çevre Eylem Programı’nın hazırlamasına yönelik bir teklif sunmuştur (T.C. Dışişleri Bakanlığı Avrupa Birliği Başkanlığı, 2021). Söz konusu programla ilgili ayrıntılı bilgi için bakınız: https://www.ab.gov.tr/fasil-27-cevre_92.html
} 


\section{Türkiye'de Çevre Politikaları}

Türkiye'de mevcut çevre politikalarının geçmişi çok uzak bir tarihe dayanmamaktadır. Çağdaş bir bakışla Türkiye'de çevre politikaları 1970'li yıllarda gündeme gelmeye başlamıştır. Öncesindeki dönemde yani savaş sonrası kurulan yeni cumhuriyetle birlikte kentlerin imarı ve güzelleştirilmesi gibi planlar göz önüne çıkmaktadır. Yine cumhuriyetin ilk yıllarında kent kanunu veya belediye kanunu gibi çevreyi koruma amacına yönelik kanunların olduğu bilinmektedir. Ancak önceden de belirtildiği gibi çağdaş bir bakış açısıyla çevre sorunlarına yönelik politikaların ülkemize girişi 1970'li yıllarda görülmektedir. Özellikle 1972 yılında düzenlenen Stockholm Konferansı Türkiye'nin çevre politikaları üzerinde ciddi bir anlam ifade etmektedir. Konferansın etkisiyle sonraki dönemde Türkiye'de Başbakanlık Çevre Müsteşarlığı kurulmuştur. Fakat aynı dönemde ortaya çıkan "Sıfır Kalkınma" anlayışı Türkiye gibi gelişmekte olan ülkeler tarafından kaygıyla karşılanmıştır. Bu anlayışın gelişmekte olan ülkeler tarafından kaygı ve olumsuz tutumla karşılanmasının sebebi çevre korumanın kalkınmanın önünde bir engel olarak görülmesidir (Hergüner \& Kalkan, 2018; Orhan, 2013; Toprak, 2003). Stockholm Konferans1 gibi uluslararas1 anlaşmalar ve konferansların etkilerini ülkemizde gözlemlemek mümkündür. Nitekim 1992'de gerçekleştirilen Rio Çevre ve Kalkınma Konferansı'nda belirlenen kararlar neticesinde sürdürülebilir kalkınma anlayışı Türkiye'nin çevre politikalarına dâhil olmuştur (Torunoğlu, 2018).

Türkiye'de çevre politikaları başlangıç döneminde devlet eliyle merkezi bir şekilde yürütülürken, ilerleyen dönemlerde yerel yönetimlere bırakılmaya başlanmıştır. Türkiye çevre politikalarını incelerken 1960 yılında kurulan Başbakanlık Devlet Planlama Teşkilatı'nın hazırladığı Kalkınma Planları'ndan da söz etmemiz gerekmektedir. Kurulduğu yıldan itibaren hazırlanan kalkınma planlarından birincisi ve ikincisinde çevre sorunları ve bunların çözüm yollarına yönelik bir bilgi bulunmamaktadır. Ancak Üçüncü Kalkınma Planı yani 1973 ve 1977 yılları arasını kapsayan kalkınma planında çevre sorunlarına ve bunların çözüm yolu gibi konularda adım atılmıştır (Torunoğlu, 2018). Türkiye'de ilk kez Üçüncü Kalkınma Planı ile gündeme gelen çevre sorunları devam eden her kalkınma planında çevre koruma, çevrenin geliştirilmesi gibi konularla ayrı bir başlık altında ele alınmıştır (Sarıçoban \& Yıldırımcı, 2015).

Türkiye'de çevre koruma politikaları açısından 1980'li yıllardan itibaren bir arayışın olduğunu söylemek mümkündür. Bu arayışlar hem kurumsal hem de politiktir. Fakat 1990'l1 yıllarda bu arayış yerini zayıf bir çevre korumacı anlayışa devretmiştir. Bu yıllarda mevcut hükümetin bir çevre politikası olmadığı için söz konusu politikalar yerini çevreciliğe bırakmıştır. Aynı dönemde kıyılar kirletilmiş, kentlerden kaynaklı problem artmış ve yasalar yolu ile bazı doğal varlıkların yok edilmesi süreci yaşanmıştır. Süregelen dönemlerde Türkiye'nin çevre politikaları açısından en önemli gelişmelerden biri 1998 yılında yayınlanan Ulusal Çevre Eylem Programı olmuştur. Bu program Dünya Bankası desteği ile hazırlanmışıı. Bu planı Devlet Planlama Teşkilatı yayınlamıştır. Sözü edilen plan çevre hakkında hazırlanmış en nitelikli belgedir. Bu plan, üretilen politikaların uyumlu bir hale getirilmesi için birçok sektöre yönelik somut adımlar içermektedir. Ancak bu planın hukuki ve yasal olarak bir yaptırımı söz konusu değildir (Hergüner \& Kalkan, 2018; Torunoğlu, 2018).

Türkiye'de ilk kez Üçüncü Kalkınma Planı ile çevre konusu güçlü bir şekilde gündeme gelmeye başlamıştır. Ayrıca ülkedeki belli çevre sorunlarına dikkat çekilmiş ve söz konusu problemlerin planlı bir şekilde araştırılması gerektiği bildirilmiştir. Dördüncü Kalkınma Planı 1979 ve 1983 yılları arasını kapsamaktadır. Bu planda yerel yönetimlere çevre düzenlemelerinde ve projeler gibi konularda yetki verilmesi ele alınmıştır (Torunoğlu, 2018).

Beşinci Kalkınma Planı 1985 ve 1989 yılları arasını kapsamaktadır. Beşinci kalkınma planına dek çevre kirliliğini minimuma indirgemek hedeflenirken beşinci plandan itibaren sürdürülebilir kalkınmayı amaçlayan planlar yapılmıştır (Karacan, 2007; Ulucak \& Erdem, 2012). $\mathrm{Bu}$ planda mevcut kirliliğin giderilmesi ve mevcut kaynaklardan, sonraki nesillerin faydalanmasi 
adına kaynak kullanımında çevrenin dengesinin gözetilmesi ve bu durumun yaygınlaştırılması üzerinde durulmuştur (Ertürk, 1998). Bu kalkınma planında değinilen bir başka konu da ilgili üniversite ve kuruluşların çevre hakkındaki araştırma faaliyetlerine destek sağlamasıdır (T.C. Başbakanlık Devlet Planlama Teşkilatı Müsteşarlı̆̆ı, 1984).

Altıncı Kalkınma Planı 1990 ve 1994 yılları arasını kapsamaktadır. Bu dönemde Türkiye'nin çevre politikası üzerinde etkili olan birçok uluslararası gelişmeler yaşanmıştır. Bu kalkınma planının en temel özelliği sürdürülebilir kalkınma teriminin ilk kez bu planda yer almasıdır (Sarıçoban \& Yıldırımcı, 2015). Bu beş yıllık kalkınma planında insan sağlığını olumsuz etkileyen çevre tahribini engelleyici yasal önlemler yer almıştır. Ayrıca çevre bozulmalarının önceden tahmin edilip tedbirlerin ona göre alınması gerektiği belirtilmiştir. Bu planda çevre bilincinin öneminden de bahsedilmektedir. Doğanın dengesinin korunması sözü geçen başka bir konudur (T.C. Başbakanlık Devlet Planlama Teşkilatı Müsteşarlığı, 1989).

Yedinci Kalkınma Planı 1996 ve 2000 yılları arasını kapsamaktadır. Bu plan temelinde bazı ilkleri barındırmaktadır ancak bu ilkler uygulanamamıştır. Yine de doğal yaşamın devamlılı̆gnda sürdürülebilir kalkınmanın önemi ve çevre gibi konularda kaygılar bulundurması açısından önem arz etmektedir (Torunoğlu, 2018). Ayrıca bu beş yıllık kalkınma planında "Çevrenin Korunması ve Geliştirilmesi" adı altında bölüm bulunmaktadır. Bu bölümde çevre yönetiminde ve karar alma süreçlerinde toplumun sorumluluk alması ve bu yüzden toplumun bilinçlendirilmesi gerektiği belirtilmiştir. Yine bu durumda eğitimin önemi ön plana çıkmaktadır (T.C. Başbakanlık Devlet Planlama Teşkilatı Müsteşarlığı, 1995).

Sekizinci Kalkınma Planı 2001 ve 2005 yılları arasını kapsamaktadır. Bu programda Ulusal Çevre Eylem Programı hazırlanmıştır. Çevre sorunlarının çözümüne yönelik kurumsal bir oluşumun inşa edilmesinde ve mevzuatlarda gelişmeler kaydedilmiştir (Sarıçoban \& Yıldırımcı, 2015; Mengi \& Algan, 2003).

Dokuzuncu Kalkınma Planı 2007 ve 2013 yılları arasını kapsamaktadır. Bu plan AB mali takvimi göz önüne alarak hazırlanmıştır. Bu sebeple yedi yıllık bir plandır (Sarıçoban \& Yıldırımcı, 2015; Ertürk, 2009). Bu planın vizyonu "İstikrar içinde büyüyen, gelirini daha adil paylaşan, küresel ölçekte rekabet gücüne sahip, bilgi toplumuna dönüşen, $A B$ 'ye üyelik için uyum sürecini tamamlamış bir Türkiye'dir" (T.C. Başbakanlık Devlet Planlama Teşkilatı Müsteşarlığı, 2006). Dokuzuncu kalkınma planında çevrenin gelecek nesilleri de dikkate alınarak korunması gerektiğinden bahsedilmektedir. Bu da sürdürülebilirliğe örnek olarak verilebilir. Eğitimin önemi ve halkın bilinçlendirilmesine yönelik bilgilendirme çalışmalarına bu planda da rastlanmaktadır. Kentleşme, ulaşım, sanayi, turizm ve tarım konularında çevreyi korumaya yönelik yönetmelikler çıkartılmıştır. Doğa koruma, atık yönetimi gibi konularda gelişmeler yaşansa da çevre konusunda yeterli düzenlemeye sahip olunamaması bahsedilen bir diğer konudur (T.C. Başbakanlık Devlet Planlama Teşkilatı Müsteşarlığı, 2000).

Onuncu Kalkınma Planı 2014 ve 2018 yıllarını kapsamaktadır. Bu planın Çevrenin Korunması adlı başlığındaki hedefleri incelediğimizde temel amaç ekonomik ve sosyal anlamda kalkınma sağlanırken, çevre hassasiyeti ve bu konudaki bilincin arttırılması olarak dikkat çekmektedir. Günümüzde yaşam ve gelecek nesillerin doğal kaynaklardan faydalanabilmesi adına çevrenin korunması, ayrıca çevrenin niteliğinin geliştirilmes, enerji, kentleşme ve tarım gibi alanlarda çevre dostu yaklaşımların (iş imkânı, teknoloji vb.) desteklenerek yeşil bir büyümenin gerçekleştirilmesi temel amaçlar arasındadır (T.C. Kalkınma Bakanlığı, 2013). Bu planda çevreye duyarlı yaklaşımların arttırılması, bölgeler arasındaki gelişmişlik düzeylerinin dengelenmesi gibi politikalara da değinilmektedir. Yeşil büyüme kavramı adı altında hem çevrenin korunması hem de rekabetin arttırılması vurgulanmaktadır. Çevre dostu yeni teknolojiler desteklenmiştir. İklim değişikliği başta olmak üzere, çevre problemlerine duyarlı politikalar sürdürülebilir kalkınma ilkeleri çerçevesinde sürdürülmüştür (T.C. Kalkınma Bakanlı̆̆ 1,2013$)$. 
On birinci Kalkınma Planı 2019 ve 2023 yılları arasını kapsamaktadır. Bu kalkınma planının Çevrenin Korunması adındaki başlığını incelediğimizde çevrenin ve kaynakların korunması niteliğinin güçlendirilmesi aynı zamanda çevrenin aktif, bütünleşmiş ve sürdürülebilir bir yönetiminin sağlanması amaçlandığı görülmektedir. Ayrıca her alanda iklim-çevre dostu uygulamaların gerçekleştirilmesi temel amaç olarak belirlenmiştir (T. C. Cumhurbaşkanlığı Strateji ve Bütçe Başkanlığı, 2019). Yine bu planda duyarlı kentleşme yaklaşımı devam etmektedir. Bunun yanında çevreye duyarlı politikalar kalkınma ilkeleri çerçevesinde yürütülmektedir. Yeşil liman uygulamaları desteklenmektedir. Bu planda çevreci ulaşım yöntemlerini özendirici çalışmalar yapılması planlanmaktadır. Toplumun her kesiminde çevre bilincinin arttırılmasına değinilmesi ile çevre eğitimi bir kez daha karşımıza çıkmaktadır (T.C. Cumhurbaşkanlığı Strateji ve Bütçe Başkanlığı, 2019).

Özetle Türkiye'de başlangıçta uluslararası sözleşmelerin büyük anlamda Türkiye çevre politikalarına yön verdiğini söylemek mümkündür. Ancak Üçüncü Kalkınma Planı'na çevre konusunun dâhil edilmesi ile birlikte hazırlanan her kalkınma planında ülke genelinde çevre sorunları ve çözümlerine yönelik somut adımlar atılmaya çalışılmıştır.

\section{Dünyada ve Türkiye’de Çevre Eğitimi Politikalarına Genel Bir Bakış}

Bu bölümde Dünyada ve Türkiye'de çevre eğitimi uygulamalarını yönlendiren çevre eğitimi politikaları incelenmiştir. Artan nüfus ve ihtiyaçlar yanında gelişen teknolojinin etkisi gibi nedenlerle çevre problemleri etki alanını genişletmektedir. Çevrenin olumsuz etkilenmesi demek tüm canlıların yaşamının tehdit altında olması demektir. Bu sebeple çevreyi korumak için bazı uygulamalar yapılmalıdır. Fakat uygulamaların hayata geçirilmesi her zaman mümkün olmamaktadır. Her şeyden önce bilinçli bireylere gereksinim duyulmaktadır ve bunun için de eğitimin yeri hafife alınmamalıdır. Çevre sorunlarının üstesinden gelmek, bilinçli ve organize bir şekilde toplumdaki bütün bireylerin eğitimiyle mümkündür (Bozkurt \& Cansüngü Koray, 2002).

\footnotetext{
"Çevre eğitimi; toplumun tüm kesimlerinde çevre bilincinin geliştirilmesi, çevreye duyarlı, kalıcı ve olumlu davranış değişikliklerinin kazandırılması ve doğal, tarihi, kültürel, sosyo-estetik değerlerin korunması, aktif olarak katılımın sağlanması ve sorunların çözümünde görev alma olarak tanımlanabilir" (Baykan, 2004).
}

Bireyin erken yaşlardan itibaren, çevre bilincine sahip olması ve sorumluluk sahibi kişilere dönüşmesi sağlanmalıdır. $\mathrm{Bu}$ da, etkili ve verimli bir eğitimle, özellikle çevre eğitimi ile sağlanabilir (Alım, 2006). Çevre eğitiminin bireylere erken yaştan itibaren verilmeye başlanması, çevre duyarlılığını artırmakta ve bireylerin davranışına olumlu şekilde yansımaktadır. Bu nedenle çevre eğitimi her eğitim gibi önce ailede başlamalı ve yaşam boyu öğrenme şeklinde devam etmelidir. Çevreye saygının, bir değer olarak eğitim sisteminde yer verilmesi bu konudaki birçok problemin çözümüne katkı sağlayacaktır (Alkayış, 2020). İlköğretimden üniversiteye kadar olan süreçte çevre eğitiminin devamlı ve planlı verilmesi, bireyi daha bilinçli ve duyarlı bir hale getirecek ve ona doğal dengeleri bozmadan sürdürülebilir davranış kalıpları kazandıracaktır (Çolakoğlu, 2010). Bireyin çevre eğitimini davranışa dönüştürmesi çevreyi koruma yolunda büyük bir adım olarak kabul edilmektedir.

Çevre eğitimi sadece örgün eğitimle değil aynı zamanda yaygın eğitimle de verilmelidir. Aileden, sokaktan, akranlarından ve kitle iletişim araçlarından öğrenilen bilgiler, okullarda edinilen bilgiler kadar önemlidir (Gökdağ, 1994). Başka bir ifade ile çevre eğitimi sadece resmi öğretim kurumlarının görevi değildir. Bu konuda gönüllü kuruluşlar, sivil toplum örgütleri ve yerel yönetimlerin çevre duyarlılık ve bilincine katkı sağlayıcı, kamuoyu oluşturucu, etkin ve dizgeli halk eğitimi etkinlikleri de göz ardı edilmemelidir (Karataş \& Karabağ, 2013). Bazı ülkelerin çevre eğitimine anayasalarında çevre hakkı çerçevesinde yer verdiği, bazı ülkelerin ise özel yasalarla bu eğitimi güvence altına aldıkları bilinmektedir (Çolakoğlu, 2010). Örneğin; 1982 Anayasası'nın 56. maddesinde herkesin sağlıklı ve dengeli bir çevrede yaşamak hakkına sahip olduğu ve çevreyi 
geliştirmek, çevre sağlığını korumak, çevre kirlenmesini önlemenin devletin ve yurttaşın görevi olduğu ifade edilmektedir (Karataş \& Karabağ, 2013). Bu gibi yasalar hakkında bireyleri bilinçlendirmek de eğitim ile mümkündür. Çünkü bireyin bilmediği bir şey hakkında sorumluluk almasının beklenmesi doğru değildir. Örneğin; bir çocuğa sobaya dokunmaması gerektiği öğretilmezse çocuk sobanın onun canını yakabileceğini bilemez. Bu sebeple bireylere doğaya nelerin zarar verdiği, bu zararların oluşturduğu sorunlar ve nasıl önlem alınması gerektiği eğitim yoluyla verilmelidir. Fakat sadece bu eğitimlerin verilmesinin de yeterli olmadığ çevreye zararlı davranışların ve etmenlerin farkında olmasına rağmen büyük bir çoğunluğun çevreye yönelik doğru davranışları uygulamaya geçirmekte eksik kaldığı gözlenmektedir (Erten, 2005). Bu sebeple de öğrenmenin tutum ve davranışa yönelik olması bu sorunu azaltmada ön plana çıkmaktadır. Örneğin ülkemizde MEB ile birlikte yürütülen ''Yeşil Kutu Projesi'” gibi birçok proje ve program yer almaktadır (Öztürk \& Erten, 2020). Bu proje, çevre hakkında toplumu bilinçlendirme ve çevre ile ilgili olumlu tutum kazandırma gibi amaçlara sahiptir.

Çevre problemleri artınca çevreyi koruma amacıyla bazı adımlar atılmaya karar verilmiştir. 1972'de yapılan Stockholm İnsan Çevre Konferansı bu konudaki ilk önemli toplantıdır. Bu toplantıda çevre sorunları uluslararası boyutta ele alınmıştır. İnsan-çevre ilişkileri, ülkelerin iktisadi gelişme sorunları, uluslararası hukuk vb. ele alınan bazı konulardır (Ökmen, 2000; Ökmen, 2004). $\mathrm{Bu}$ konferansta ayrıca çevre sorunlarının evrensel olduğu öne çıkarılmıştır. Örneğin; bir ülkenin havaya saldığı zararlı kimyasalların ozon tabakasına zarar vermesi sadece o ülkeyi değil dünyadaki bütün ülkeleri etkilemektedir. Bu sebeple çevreyi koruma sorumluluğu tüm bireyler ve ülkeler tarafından alınmalıdır. Konferansa 113 ülke katılmıştır. Bu konferanstan sonra Birleşmiş Milletler Çevre Programı (UNEP) kurulmuştur (Keleş \& Hamamc1, 2002). Ayrıca Stockholm Konferansı'nın etkisi ile 1975 yılında Uluslararası Çevre Eğitim Programı (IEEP) düzenlenmiştir. 1977'de Tiflis'te yapılan ve çevre eğitiminin amaçlarının yer aldığı Çevre Eğitimi Konferansı bu konudaki ilk toplantıdır (Akçay, 2006). Daha sonra 1987'de yapılan Çevre ve Kalkınma Raporu diğer adıyla Brundtland Raporu'nda sürdürülebilir kalkınma ön plana çıkmıştır (Ozmehmet, 2008). 1992'de yapılan Rio Konferansı'nda beş belge yer almaktadır. Bunlar; Çevre ve Kalkınma Üzerine Rio Deklarasyonu, Gündem 21, Ormanların Kullanım Bildirisi, İklim Değişikliği Çerçeve Anlaşması ve Biyolojik Çeşitlilik Antlaşması'dır (Akçay, 2006). 1997'de gerçekleştirilen Seul Çevresel Etik Konferansı'nda çevre eğitiminin öneminden bahsedilmektedir (Doğan, 1997). Ayrıca konferansta bu eğitimin erken yaşlardan itibaren ele alınması gerektiği de belirtilmiştir. 2002 Johannesburg Zirvesi, Rio Konferansı'nın değerlendirilmesi ve gelecekteki kalkınma stratejilerini belirlemek için yapılmıştır. Bu toplantıya her kesimden bireyin katılımının sağlanması ve herkesin sorumluluk alması amaçlanmıştır. Ayrıca bu zirvede nelerin yapılmasından ziyade nasıl yapılması gerektiği ön plana çıkarılmışır (Akçay, 2006).Söz konusu zirvede uygulama aşamasına yön verildiği söylenebilir.

Birleşmiş Milletler çatısı altında IEEP ve UNESCO gibi kuruluşlar faaliyet göstermektedir. $\mathrm{Bu}$ kuruluşlar ile OECD himayesinde kurulan Çevre ve Okul İnisiyatifleri (ENSI) gibi kuruluşlar işbirliği yaparak ortaya çıkardıkları çalışmalar ile çevre eğitimini yaygınlaştırmaktadırlar. $\mathrm{Bu}$ çalışmalara örnek olarak eko-okullar verilebilir (Akçay, 2006). Eko-okullar, lise dönemi öncesindeki eğitim kademelerinde öğrencilere çevre bilincini ve duyarlılığını kazandırmak amacıyla oluşturulan uluslararası bir programdır. Eko-okullar programı sadece okulda değil okul çevresinde de çevre bilinci ve sorumluluğu kazandırmaktadır (Yüksel, 2020). Bu sebeple uygulamanın geniş alanda fayda sağladığı söylenebilir.

\section{Türkiye'de Çevre Eğitim Politikaları}

Türkiye'de çevre eğitimi, genellikle kendiliğinden gelişen ve ilerleyen bir süreç olarak devam ettiği için bu konuda arzu edilen sonuç alınamamaktadır (Çolakoğlu, 2010). Geleneksel çevre eğitimi, çevre koruma ve uygulamaları gibi kısıtlı konuları ele alması sebebiyle yetersiz 
kalmaktadır. Bu sebeple sürdürülebilir kalkınma amaçlı eğitime geçilmesi gerektiği belirtilmektedir (Özdemir, 2007).

Ülkemizde çevre hakkı kavramı 1982 yılında anayasada yer almasıyla birlikte gündeme gelmesine rağmen, 1991 yılına kadar çevre eğitiminden söz edilmemiştir. 1992'de Milli Eğitim Bakanlığ 1 tarafindan ilkokuldaki tüm kademelere çevre ile ilgili ders konulsa da 1997'de bu uygulamadan vazgeçilmiştir (Alkış, 2002). 1991'de Çevre Bakanlığ 1 kurulmuştur. Çevre Bakanlığı ve Milli Eğitim Bakanlığı arasında 1999'da çevre derslerinin zorunlu olması gibi kesin kararlar içeren işbirliği protokolü imzalanmıştır. Çevre eğitiminin uygulamalı olarak yapılmasına önem verilmesi, ortaöğretimde ise çevre dersinin bir saat zorunlu olarak verilmesi, tüm ülkede hizmet içi eğitim kursları aracılığıyla çevre bilincine vurgu yapılması gibi çalışmalar da bu protokolde yer almaktadır (Alım, 2006). Pandeminin etkisi ile bu dönem ara verilmiş olsa da TÜBİTAK'ın desteği ile ülkemizde doğa eğitimi kampları düzenlenmektedir.

Günümüzde ilköğretimde ve lise kurumlarında çevre adı altında zorunlu ders bulunmamakta, çevre ile ilgili konulara başka dersler adı altında yer verilmektedir. Fakat 2004 yılında değişen program ile birlikte ortaokul müfredatında seçmeli Çevre Eğitimi dersine yer verilmiştir. $\mathrm{Bu}$ dersin seçmeli olmasının günümüzdeki çevre sorunları göz önüne alındığında ne kadar doğru olup olduğu tartışmalıdır. Böyle olmakla birlikte değişen bu programla birlikte aynı zamanda müfredattaki çevre kazanımları da arttırılmıştır. Okul öncesi kademelerde çevre eğitimi genel olarak "Fen ve Doğa Çalışmaları" adlı derste yer almaktadır. Fakat disiplinler arası da işlenebilmektedir. Disiplinler arası işlenmesi konunun her açıdan öğrenilmesine katkı sağlayabileceği gibi ayrı bir ders olarak da verilmesi gerektiği aşikârdır. Bu derste çocukların çevrelerini tanımaları için çeşitli etkinlikler yapıldığı gibi aynı zamanda atık malzemeler ile nesneler yapılarak geri dönüşüm bilinci de kazandırılmaya çalışılmaktadır. Bunların yanı sıra çeşitli doğa gözlemleri ve deneyler de yapılabilmektedir (Akçay, 2006). Yaparak ve yaşayarak öğrenme yani yapılandırmacı yaklaşımın öğrencilerin öğrenmesine büyük katkı sağladığı düşünüldügünde bu gibi etkinliklerin çevre eğitiminin verilmesinde oldukça etkili olduğu söylenebilir. Çevre zarar görürse herkes zarar göreceği için çevreyi korumak hepimizin sorumluluğudur. Bu durum çevre eğitiminin, toplumun her kademesine ulaşması gerektiğini gösterir. Söz konusu süreci şekillendirecek ve yönlendirecek olan da siyasi iradedir.

\section{Bazı Ülkelere Ait Çevre Eğitimi Politikaları}

Aşağıda bazı ülkelerin çevre eğitimi politikalarıyla ilgili bilgiler yer almaktadır. $\mathrm{Bu}$ açıklamalarda ülkelerin çevre eğitimiyle ilgili başlıca özelliklerine de değinilecektir.

\subsection{Almanya'da Çevre Eğitimi Politikaları}

Almanya'da 1970'li yılların sonlarından itibaren disiplinler arası çalışmalar desteklenerek okullarda çevre eğitimi verilmeye başlanmıştır (Şafak \& Erkal, 1999). 1977'de Tiflis'te düzenlenen Birinci Dünya Konferansı için hazırlanan "Çevre Eğitimi Ulusal Raporu” çevre eğitimi müfredatını geliştirmek için somut girişimlerin başlangıcı olarak kabul edilebilir (Bolscho \& Hauenschild, 2006). 1980'lerin başlarında yapılan müfredat çalışmalarında biyoloji ve coğrafyanın çevresel konuları ele aldığı ve ana disiplinler olduğu belirtilmektedir. Almanya'da öğretmenlerin müfredata uygun ders vermeleri zorunlu olduğundan çevre eğitimine yeteri kadar değinilmemektedir. 19861996 y1lları arasında 30'dan fazla çevre eğitimi projesi üstlenen Almanya, bu projelerde nadiren yenilik stratejilerinden bahsetmektedir. Almanya, OECD tarafindan yürütülen ve öğrencilerin matematik, fen gibi alanlarda başarılarını ölçmeye yarayan PISA çalışmasına katılmıştır. Bu katılım eğitim politikası oluşturmak açısından rehber haline gelmiştir (Seybold \& Rieß, 2006). Bütün ülkedeki eğitim politikasının koordinasyonu ve onaylanması KMK (Eyaletler Eğitim Bakanlarının Almanya Federal Cumhuriyeti'ndeki Daimi Konferansı) tarafından yapılmaktadır (Akçay, 2006). Federal Eğitim ve Araştırma Bakanlığı ile Bundesländer işbirliği yaparak 5.sınıftan 12.sınıfa kadar 200'den fazla okulda ülke çapında BLK'21 programını başlatmışlar ve finanse 
etmişlerdir. Sivil Toplum Kuruluşları'nın projeleri genellikle Gündem 21 grupları ile ilgili olup çoğunluğu okullarla işbirliği içinde yürütülmektedir. Çevre eğitimi hakkında öğretim materyalleri geliştirilmekte, diğer derslerle entegre edilmekte ve çevre eğitiminin geliştirilmesi için sınıf dışı uygulamaların arttırılması girişimleri yapılmaktadır. Yetişkin eğitiminde öncelik su ve enerji tasarrufu gibi evde uygulanabilecek bilgileri iletme odaklı olup küresel koruma geri planda kalmaktadır (Bolscho \& Hauenschild, 2006). Almanya'da çocukların doğaya karşı pozitif davranışlar edinebilmeleri için ilk kez Norveç'te kurulan Nature Waldkindergarten'lar açılmıştır (Akçay, 2006). Bu okullara doğa temelli okullar da denilebilir. Alman Doğa ve Çevre Koruma Derneği (BUND), Alman Çevre Kampanyası, Greenpeace Almanya, Alman Doğa Koruma Birliği (NABU), Dünya Doğa Fonu (WWF), Alman Ormanları Koruma Derneği, Alman Çevre Eğitimi Derneği (DGU), Doğa ve Çevre Eğitimi Çalışma Grubu (ANU) bölgesel olarak faaliyet gösteren derneklere örnektir (Bolscho \& Hauenschild, 2006).

Almanya'da Sürdürülebilir Çevre Eğitimi, Milli Komite denen üst düzey bir kuruluş tarafından organize edilmektedir. Bu komite birkaç eyalet ve ulusal bakanlık, Parlamento, sivil toplum kuruluşları, medya, özel sektör ve bilimsel topluluktan oluşmaktadır. Ulusal Komite paydaşlar arasında arabuluculuk yapmakta, ulusal uygulamaları uluslararası bakış açısına uyarlamaktadır. Ulusal Eylem Planının birincil hedefi sürdürülebilirlik fikrini tüm eğitim alanlarına yerleştirmektir. Her sene 16 eyaletin de temsil edildiği Yuvarlak Masa (The Round Table) adlı toplantıda sürdürülebilirlik ve eğitim paydaşları bir araya gelmektedir. Çalışma grupları sürdürülebilir kalkınmayı kendi eğitim alanlarına uygulamak için somut kurallar oluşturmaktadır. $\mathrm{Bu}$ koordinasyon bakanlıklardaki karar vericiler ve sahadaki paydaşlar arasında köprü kurma özelliği göstermektedir. Ulusal Eylem Planı ESD (Sürdürülebilir Kalkınma Eğitimi) alanını tanıtmak ve desteklemek için bu alanda yenilikçi projeleri ödüllendirmektedir. Bu kapsamda 2000 'den fazla proje ödüllendirilmiş ve iyi örnek olarak duyurulmuştur. Son 10 senedeki faaliyetler yerel, eyalet ve ulusal düzeylerde politik, düzenleyici ve uygulayıcı alanlarda ESD'nin yer almasını ve etkinliğinin artmasını sağlamıştır (Chandran et al., 2017).

\subsection{Ingiltere'de Çevre Eğitimi Politikaları}

Çevre eğitimi İngiltere'de 1970'li yıllarda başlamıştır. Mayıs 1988'de Avrupa Topluluğu Konseyi Toplantısı'nda Britanya Hükümeti çevre eğitimi hususundaki bakış açısını ileri seviyeye taşıma kararı almıştır. Avrupa Topluluğu Konseyi Toplantısı'nda bazı prensipler ve amaçlar belirlenmiştir:

belirlemek.

Çevre sorunları hakkında toplum bilincini artırmak ve muhtemel çözümleri

- Çevrenin korunması ve doğadaki mevcut kaynakların en doğru biçimde kullanılması konusunda bireylerin aktif katılımını sağlayacak ve bilgilendirecek kurumları kurmak.

Rehberlik edecek ilkeler ise şöyle belirlenmiştir:

- $\quad$ Çevre, insanlığın ortak mirasıdır. İnsan sağlığının ve ekolojik dengenin korunması için evrensel değerlerin korunması ve geliştirilmesi ortak bir görevdir.

- Doğal kaynaklar mantıklı ve doğru kullanılmalıdır.

- Doğanın korunmasında nası1 rol alacağı her bireye öğretilmelidir (Öner \& Arslan, 2005).

1990 'da İngiltere'de yaymlanan National Curriculum Documentation for Environmental Education (Çevre Eğitimi için Ulusal Müfredat Belgesi) adlı belgede çevre meselelerinin öğretilmesini zorunlu kılınmıştır. Mevcut müfredat, Ulusal Müfredat Kurulu'nun çevre eğitimi kılavuzunu yayınlamasıyla tamamlanmıştır (National Curriculum Council, 1990). Bu belge okulların ulusal müfredat vasıtasıyla çevre konularını nasıl öğretecekleri ve yasal zorunluluklar 
ötesine ne kadar geçebileceklerini içermektedir. Bazı müfredat alanlarında, özellikle Coğrafya ve Fen Bilimlerinde, çevre konularının öğretilmesi zorunlu kılınmıştır. Eğer okullar çevre boyutu içeren bir öğretim programı fırsatı sunmak isterlerse zorunlu olmamakla beraber çevre konularının diğer müfredat alanlarına eklenebileceği belirtilmiştir. Yine İngiltere'de 1993 yılında Toyne Report adında yayınlanan bir belgede çeşitli öğretim seviyelerinde uygulanacak çevre eğitimine yönelik içerik oluşturulmuştur. An Agenda for Further Higher Education (Çevresel Sorumluluk: Yüksek Öğretim İçin Bir Gündem) adlı programı yayınlayan komite tüm yükseköğrenim kurumları ve üniversiteler için şu maddeleri önermiştir:

1) Kapsamlı bir çevre politikaları beyannamesi,

2) Çevre eğitimi gelişimi için bir politika ve strateji,

3) Bunların uygulanması için hareket planları.

Örgün eğitim dışında uygulanacak çevre eğitimi bu ajandada ciddi olarak içeriğe dâhil edilmiştir. Bundan sonra 1996'da, İngiltere Hükümeti'nin örgün ve yaygın eğitim üzerine eğitim stratejisi şu şekilde belirlenmiş̧ir: Tüm yaş gruplarında, örgün eğitimden yaygın eğitime kadar, sürdürülebilir kalkınma kavramları ve ulusal vatandaşlık yükümlülükleri öğretilmelidir. Vatandaşların ev ve iş yaşamındaki çevre ve kalkınma sorunlarıyla başa çıkma kapasiteleri geliştirilmeli ve güçlendirilmelidir (Department of Education (Northern Ireland), 2001).

Hükümet tarafından, 2011 yılında, sürdürülebilir kalkınma konusunda bağımsız bir danışma organı olan Sürdürülebilir Kalkınma Komisyonu kapatılmıştır. İngiltere tarafından desteklenen Defra Politikaları'nda çevre eğitimi ile ilgili maddelere rastlanmaktadır. Defra'nın 2015-2020 strateji belgesine göre, örneğin gıda ve çiftlikçilik için çıraklık eğitimine yönelik yüksek kaliteli eğitim ve öğretim imkânı sunulması ile kırsal alanların ekonomik potansiyelini açığa çıkarmak gereksinimi vurgulanmıştır. Yerel yönetim otoritesi ilk olarak öğretmenler için mesleki gelişim imkânı sunmuş ve açık alan öğretimini teşvik etmiştir. LA web siteleri öğretmenleri "Sürdürülebilir Kalkınma Eğitimi” ile ilgili çevrimiçi eğitime yönlendirmiştir. Bu kaynaklar müfredatı genişletmek için fırsatlar sunmaktadır. Ulusal politika, çevre eğitiminin çoklu boyutlarını tanımalı ve bir öğrencinin okul hayatı boyunca bu boyutları kapsayan bir eğitim almasını sağlamalıdır (Glackin \& King, 2018).

\subsection{Rusya'da Çevre Eğitimi Politikaları}

26 Nisan 1986'da meydana gelen Çernobil kazasıyla birlikte Rusya'nın çevre politikası yıkıma uğramıştır. Bu yılların sonuna doğru sadece çevreyi kirletenlerin ceza almasına yönelik iki madde dışında çevre ile ilgili somut bir kanun maddesi bulunmamaktadır (Aliyev, 2013).

Rusya Federasyonu'nda çevre eğitimi ve sürdürülebilir kalkınmadan 1990'ların ortalarından itibaren aktif olarak bahsedilmeye başlanmıştır. Rusya Federasyonu'nun çevre eğitimi alanındaki devlet politikası; doğa koruma örgütleri ve okulların sosyal etkileşimi, çevre eğitimi için bilgilendirme ve teşvik edici destek, eğitim sürecinin sürekliliği gibi ilkelere dayanmaktadır. Çeşitli zorluklara rağmen sürdürülebilir eğitim, bütün eğitim seviyelerinde verilmektedir. Doğa ve birey arasındaki çevre sorunları derslerde disiplinler arası olarak yer almaktadır. Sürdürülebilir kalkınma eğitimi için son 10 yılın sonuçlarına bakıldığında sürdürülebilir kalkınma kavramının uygulanmasında öncelikler haline gelen konular Rus okul eğitiminin içeriğinde yer almaktadır. İklim Değişikliği Çerçeve Sözleşmesi'nin 6.maddesinde yer alan iklim değişikliği konusu, Biyolojik Çeşitlilik Sözleşmesi'nin 13.maddesinde yer alan biyolojik çeşitlilik konusu, Hyogo 2005-2015 Eylem Çerçevesi'nde yer alan afet riskini azaltma konusu bu konulardan bazılarıdır. Rusya Federasyonu'nda sürdürülebilir kalkınmaya geçiş kavramı 1 Nisan 1996 tarih ve 440 sayılı Cumhurbaşkanlığı Kararnamesi ile onaylanmıştır (Shutaleva et al., 2020). 
1514 Ali Ekber Gülersoy - Hilal Yener - Tuğçe Turgut - Dilay Melis Özşahin - Deniz Anter...

\subsection{Finlandiya'da Çevre Eğitimi Politikaları}

Finlandiya' da çevre eğitimi ilköğretimde zorunlu olarak yer almaktadır. Finlandiya'daki ilk doğa gezileri 1950'lerde yapılmaya başlanmış ve 1970'lerde resmi programa dâhil edilmiştir. Doğa ve çevre okulları, fonlarını diğer okullara benzer şekilde yerel belediyeden almaktadırlar. Okullarda Gündem 21'in ilkeleri dikkat alınmaktadır (Jeronen et al., 2009). Çevre konuları genellikle okul dışı etkinliklerle yaparak ve yaşayarak öğretilmektedir. Finlandiya, okul dışı öğrenme yöntemlerini eğitim programına uygun hale getirmiştir. Finlandiya'da başarının temeli öğretmen olarak görüldüğü için öğretmen eğitiminde değişiklikler yapılıp bu alanda bilgi sahibi öğretmenler yetiştirmek amaçlanmıştır (Özdemir, 2017). Eğitim politikaları 1990'larda yeni kamu sektörü yönetimi ve diğer neo-liberal politikaların bir sonucu olarak değişse de Finlandiya baskın eğitim reformlarını yavaş yavaş uygulamıştır. Finlandiya eğitiminin odak noktası öğrencileri sınava hazırlamak yerine aktif öğrenme olduğundan farklı öğretim yöntemleri rahatlıkla kullanılabilmektedir. Finlandiya'nın eğitim sistemi 1980'lere kadar merkezi olarak düzenlenmiş, yoğun kurallar ile öğretmenlerin çalışma alanlarına müdahale edilmiştir. İlk reform hareketi ile birlikte 1990'larda Finlandiya'da güvene dayalı bir okul kültürü dönemi resmen başlamıştır (Sahlberg, 2007).

\subsection{Slovakya'da Çevre Ĕgitimi Politikaları}

Sürdürülebilir Kalkınma Eğitimi, Slovakya'da 2005 'te yürürlüğe konulmuştur. Üst düzey taahhütler, hükümet direktifleri, mevzuat değişiklikleri, öğretmen eğitimine yönelik uygulamalar yapılmıştır. İlkokul ve ortaokul müfredatları çok kültürlü eğitim, kişisel ve sosyal gelişim, çevre eğitimi ve sağlıklı yaşam tarzlarını bir arada bulundurmaktadır. Okul öncesi eğitiminde çevre eğitimi çok disiplinli, sarmal olarak uygulanmaktadır. Bakanlığın direktiflerini uygulama aşamasında okullara özerklik verilmiştir. Bazı okullar çevre ve sürdürülebilirlik konularının öğretimini derslere paylaştırırken, bazıları da sürdürülebilir sınıflar oluşturmakta ve çevre projeleri planlamaktadır (Chandran et al., 2017).

\subsection{Bulgaristan'da Çevre Eğitimi Politikaları}

Bulgaristan hem uluslararası gelişmeleri hem de ülkenin sosyal, kültürel ve ekonomik durumunu dikkate alarak çevre eğitimi politikası geliştirmiştir. 1972 yılından önce çevre eğitimi doğa sevgisine ve doğaya özen göstermeye yöneliktir ve folklor, şiir, edebiyat vasitasıyla uygulanmaktadır. Doğal kaynakları koruma, ormanlaştırma, sanayileşme ve şehirleşme, tarım ilaçları gibi konulara odaklanan çevre eğitimi; Doğa Çalışmaları Birliği (1896), Doğayı Koruma Birliği (1927) gibi kuruluşların faaliyetleri, okul içi ve okul dışı aktiviteler, müfredatta yapılan düzenlemelerle uygulanmıştır. Her aileye bir haftalığına ağaç dikme, bahçe ve park düzenleme gibi çevre etkinlikleri yaptırılan dönemler olmuştur. 1972-1992 arasında hava kirliliğini ve su israfını önlemeye yönelik teknolojiler araştırılmış ve doğa koruma mevzuatı çıkarılmıştır. 1972 yılında Çevre Eğitimi Araştırma Ekibi (NIER) kurulmuş, 1984'te yuva çağından yükseköğrenime hatta hayat boyu öğrenmeyi savunan bir program geliştirilmiştir. Fen eğitiminde yeni müfredat ve yeni kitaplar geliştirilmiş, çevre eğitimi yükseköğrenime eklenmiştir. 1981'de öğretmenler için kılavuz niteliği taşıyan ve içinde pek çok pedogojik uygulama bulunan ekoloji kitabı Angelov tarafindan yazılmıştır. 1992'den sonra doğal kaynakların aşırı kullanımı, işsizlik sorunlarına yönelen Bulgaristan'da üniversitelerde çevre eğitimine yönelik araştırmalar yapılmaya başlanmış, birçok okul ve üniversitede sürdürülebilir kalkınma eğitimi verilmeye başlanmıştır. Biyolojide ekoloji eğitimi ve tüm derslerde çevre eğitimi konularına yer verilmeye başlamıştır. Sürdürülebilir kalkınma eğitimine yönelik eğitim reformları güncellenmiş, öğrenme ve öğretme materyalleri, interaktif eğitim teknikleri geliştirilmiş, kolejlerde ve üniversitelerde çevre eğitimine yönelik kurslar düzenlenmiş ve uzmanlar yetiştirilmiştir. Yaşam boyu eğitim faaliyetleri güvence altına alınmıştır. Son dönemde önceki dönemlerde var olan bazı çevre değerlerinin unutulduğu saptanmıştır. Bunun yanında ekonomik ve finansal sorunlar artarken kaynaklar tükenmekte ve 
ekolojik ekonomiye gereken önem verilmemektedir. Sınıf dış1 ve okul dış1 etkinliklere gerektiği kadar yer verilmediği de dikkat çekmektedir (Soykan vd., 2012).

\subsection{Yunanistan'da Çevre Eğitimi Politikaları}

1987-1988 yıllarında 58 okul bölgesinde çevre eğitimi için bölge sorumluları tayin edilmiştir. 1990'l1 yıllarda çevre eğitim merkezleri kurulmaya başlanmıştır. 2001 yılında Yunan Eğitim Bakanlığı tarafından pilot proje kapsamında "Esnek Bölge", bütün okullarda yürürlüğe sunulmuştur. Hükümet, çevre ve çevre eğitimi konusunda duyarlıdır ve gerekli fon desteğini sağlamaktadır (Artun \& Bakırc1, 2012).

\subsection{Güney Afrika'da Çevre Ĕgitimi Politikaları}

Güney Afrika, çevre problemlerine ilişkin gereken önlemleri sağlamak için birden fazla uluslararası sözleşme ve anlaşmayı doğrulamıştır. Sözü edilen sözleşme ve anlaşmalardan bazıları şunlardır; 1997'de Birleşmiş Milletler Çevre Programı altında Toprak Yıkımının Küresel Değerlendirmesi, 1997'de Birleşmiş Milletler Sözleşmesi, 1997'de Birleşmiş Milletler Çölleşmeyle Mücadele Antlaşmas1, Biyolojik Çeşitlilik Kongresi (Loubser, 2009).

Ülke içinde çevre eğitimi hususunda mevcut münakaşalar çevre eğitiminin sosyal, ekonomik ve politik olarak bütünleşmesini sağlamıştır. Güney Afrika'da, Çevre Eğitimi Programını evrensel hale getirebilmekle ilgili deneme girişimleri olmuş olsa da en uygun girişim 1971'de gerçekleşebilmiştir. Bu girişim ise uluslararası çalışma grubunca yapılmıştır (Artun \& Bakırcı, 2012; Loubser, 2009; O’Donoghue, 1993).

Ülkede çevre eğitiminin yasal olarak uygulandığı eğitim birimi üniversitelerdir. Yine ülkede çevre eğitiminde verilen kurs derslerini ve programlarını Bophuthatswana Üniversitesi programlamaktadır. Öte yandan Güney Afrika'da Rhodes, Güney Afrika ve Stellenbosch üniversiteleri çevre eğitimi üzerine önemli çalışmalar yapmışlardır (Artun \& Bakırc1, 2012; Irwin \& Lotz-Sisitka, 2005; Loubser, 2009).

Ekosistemin bozulması, su kirliliği, temel hakların ihlal edilmesi, yoksulluk gibi nedenler sağlık sorunlarını artırmaktadır. Bu nedenle hastalıkların yaklaşık \%75'den fazlasının Afrika'da görüldüğü söylenebilir (Tepebaş, 2009). Southern African Development Community (SADC) üye devletleri, çevre eğitimi politikasının uygulama aşamasında yoksulluk ve HIV/AIDS vb. hastalıkların yaşanması gibi bazı zorluklar yaşamıştır (Obol et al, 2003). Güney Afrika, çevre sorunlarını önlemek amacıyla Birleşmiş Milletler Sözleşmesi ve Biyolojik Çeşitlilik Kongresi gibi bazı uygulamalara katılmışır (Artun \& Bakırc1, 2012). 1992 Dünya Zirvesi ve Gündem 21, bölgedeki çevre eğitimi yaklaşımını etkilemiş ve çevre eğitimi için altyapının oluşmasını sağlamıştır (Obol et al., 2003). Güney Afrikalı eğitimciler, Çevre Eğitimi Programı'nı 1971'de evrenselleştirebilmişlerdir. 2005 yılında yenilenen eğitim programıyla çevre konuları geliştirilmiştir (Artun \& Bakırc1, 2012). Küresel çevre eğitimi politikası, çevrenin her seviyede kalkınma planlarına dâhil edilmesini önermektedir. Çevre eğitimi politikaları ile iki veya daha fazla sayıda bakanlık ilgilenmektedir (Obol et al., 2003).

\subsection{Kenya'da Çevre Ĕgitimi Politikalart}

Dünya genelinde çevre eğitiminin ender olarak okul müfredatlarında önceliği olmuştur (Jacobson \& McDuff, 1998; McDuff, 2000). Okullar içerisinde çevre eğitiminin önündeki kritik engeller; zaman, imkân ve finans olarak değerlendirilir (Ham \& Sewing, 1988; McDuff, 2000). Afrika'daki yaban hayatı kulüpleri adımı, bu kıtada yaşayan öğrenciler için en büyük koruma düzenlemesi olmuştur. 1968'li senelerde kendisini gösteren Kenya Vahşi Yaşam Kulüpleri, evrensel olarak ilk vahşi yaşam kulübü olarak kayıtlara geçmiştir. Bu teşkilatın 1970'li senelerde Kenya'da ilerleme kaydetmesi, Afrika'daki yaban hayatı kulüplerinin önünü açmıştır. Vahşi yaşam kulüpleri Afrika'da İngilizce konuşulan 17 ülkede ve Fransızca konuşan 10 ülke içerisinde 
bulunmaktadır (Boulton \& Eddershaw, 1997; McDuff, 2000). Günümüzde Afrika dışında Asya, Latin Amerika, Avustralya ve Avrupa'da vahşi yaşam ve çevre kulüpleri yer almaktadır (McDuff, 2000).

Çevre eğitimi temelli okullar yapmayı amaç haline getiren çalışmalardan birisi ise uluslararası nitelikte olan Eko-Okullar Projesi'dir. Bu proje, 30 ülkede ve yaklaşık 7500 ilköğretim okulunda çevre bilinci ve yönetimi, sürdürülebilir kalkınma üzerine eğitim vermek için uygulanmaktadır. Kenya, Eko-Okullar projesini uygulamaya alan ülkeler arasında yer almaktadır (Aktepe \& Girgin, 2009).

\subsection{Malawi’de Çevre Eğitimi Politikaları}

Malawi'de yıllar geçtikçe çevre problemlerine olan ilginin fazlalaştığı görülmektedir. Malawi'de çevre problemlerinin su üstüne çıkması üzerine değerlendirme toplantısı düzenlenmiş ve bazı protokoller imzalanmıştır. Çevre problemleriyle ilgili tartışmalar yerel medyada yer almıştır. Buna ilaveten çevre sorunları, okullarda verilmekte olan öğretim programlarının içeriğinde de görülmektedir. Ayrıca çevre üniteleri ve konuları, ilköğretim düzeyinde öğretim programının \%80'ini, ortaöğretimde ise \%62'sini oluşturmaktadır (Artun \& Bakırc1, 2012; Phiri, 2009).

Ülkedeki çevre eğitiminde görülen başlıca problemler şöyledir; sınıf mevcutlarının çok kalabalık olması, öğrencilerde bulunan çevreye karşı duyarlılığın eksik olması, çevre söz konusu olduğunda öğretmenlerin eğitimlerinin yetersiz kalması ve çevre eğitimi ile alakalı olarak öğretim araç ve gereçlerinin eksik olmasıdır (Artun \& Bakırc1, 2012; Glasson et al., 2006).

Malawi'de çevre problemlerinin çözümünde ve problemlerin farkında olunmasında sivil toplum kuruluşları ve gazete, dergi, televizyon, radyo gibi yayın organlarının da etkili olduğunun söylenmesi mümkündür. Bu kurum ve kuruluşların çeşitli yayınlar ile birlikte çevre programları hazırlayarak çevre bilincinin oluşumunu sağlamada etkili olduğu fark edilmektedir (Allen et al., 1996; Artun \& Bakırc1, 2012).

2001 çevre eğitim politikası hala geliştirilme aşamasındadır ve erken çevre eğitim stratejisi uygulanmaktadır. Politika uygulama faaliyetleri arasında parlamenterler ve kabine bakanları için çalıştaylar yer almaktadır (Obol et al., 2003).

\subsection{Botsvana'da Çevre Eğitimi Politikaları}

1994'te yenilenen eğitim politikası çevre eğitimini sisteme infüzyon yaklaşımıyla dâhil etmiştir. Çevre eğitimi ile ilgili RNPE (Revised National Policy on Education) bildirimi Müfredat Geliştirme ve Değerlendirme Departmanı'nın sorumluluğundadır. Okul yönetimlerinin ve öğretmenlerin uygulayacağı eğitimin kılavuzunu oluşturan bölümün müfredat ve materyal geliştirme, izleme, değerlendirme gibi sorumlulukları vardır. Örgün eğitimde zaman kısıtlılığı, yeterli öğretim materyali bulunmaması, okul dışı etkinliklere katılımın az olması gibi sorunlar başka eğitim yöntemlerinin denenmesine sebep olmuştur (Ketlhoilwe, 2007). Okul Sivil Kulüpleri'nin 6 haftalık açık hava etkinlikleri gibi uygulamalarıyla öğrencilerin çevre hakkında daha iyi bilgilendikleri ve olumlu tutum ve davranışlar kazandıkları gözlemlenmiştir (Ajiboye \& Silo, 2008).

Botsvana'nın genel bir çevre eğitimi politikası olmamakla birlikte Çevre Eğitim Vizyonu 2016, bilinçli ve çevre eğitimli bir ulus çağrısında bulunmaktadır. Okullarda, çevre eğitimi uygulamalarını teşvik etmek amacıyla pilot projeler yürütülmektedir ve bu girişimi desteklemek için Kapasite Geliştirme Ağı Programı'ndan (NETCAB) fon sağlanmıştır (Obol et al., 2003). Politika oluşturma aşamalarında sivil toplum kuruluşları, bireysel kuruluşlar ve devlet kurumları yer almaktadır (Ketlhoilwe, 2007). 


\subsection{Tanzanya'da Çevre Eğitimi Politikaları}

Güney Afrika Kalkınma Topluluğu'na üye olan 13 ülkeden biri olan Tanzanya 1961'de bağımsızlı̆̆ını kazansa da İngiliz Eğitim Sistemi'nin etkileri devam etmiştir. 1975'te üretilen The Education of Self Reliance (ESR) politikası, sorgulayan zihin, topluma katkıda bulunma, ulusal kültür inşa etme gibi amaçlar barındırmaktadır. Tanzanya'da çevre eğitim politikaları, 1992 yılında yapılan Birleşmiş Milletler Çevre ve Kalkınma Konferansı'ndaki önerilere dayanılarak geliştirilmiştir. Rio Dünya Zirvesi’nin de etkisiyle çevre sorunlarını çözebilen ve sürdürülebilir kalkınmaya hizmet eden bireylerin yetişmesi için Tanzanya Eğitim Enstitüsü (TIE) ve Eğitim ve Kültür Bakanlığı (MoEC) müfredat oluşturmuştur. 1993'te Sosyal Bilimler alanında yapılan değişiklerin içinde çevre yıkımlarıyla savaşma hedefi konulmuştur. Konferans sonucu Tanzanya eğitim ve öğretim politikasında çevre eğitimi ifadelerinin kullanılmasına ve Ulusal Çevre Politikasının (NEP) oluşturulmasına yol açmıştır (Makundi, 2003). 1994 Ulusal Çevre Eylem Planı ve 1997 Ulusal Çevre Politikası, Tanzanya'daki çevre eğitimi politikası süreçlerini yönlendirmiştir (Obol et al., 2003). Müfredatı geliştiren kişiler çevre eğitimini bütünsel (çok disiplinli) bir yaklaşımla müfredata yerleştirmiştir. Çevre eğitimi, genel olarak çevrenin biyofiziksel yönüne odaklanmakta ve farkındalık yaratma ön plana çıkmaktadır. ESDP (Education Sector Development Program), "herkes için eğitim" ve insan haklarına sayg1 gerektiren uygun eğitim ve öğretim ortamları bakımından destekleyicidir. 2001 İlköğretimi Geliştirme Planı da bu belgeye dayanmaktadır. 1995 tarihli Tanzanya Eğitim ve Öğretim Politikası (ETP) bağlamında çevre eğitiminin ilk odağı biyofizik olmuştur fakat bu politika çevre sorunlarını bütünsel olarak ele almıştır (Makundi, 2003). Ulusal Çevre Yönetimi Konseyi, Tanzanya için ulusal bir çevre eğitimi stratejisi geliştirmektedir (Obol et al., 2003).

\subsection{Güney Kore'de Çevre Ĕ̈itimi Politikaları}

1990'l1 y1llardan beri eğitim reformunu devam ettiren Güney Kore'de Başkanlık Komisyonu 1995'te Cumhurbaşkanı'na Eğitim Reformu adında genel bir reform planı sunmuştur. 2000 yılında Yaşam Boyu Öğrenme Yasası genel bir yapılandırma ile yürürlüğe sunulmuştur (Erdik, 2016). Eğitim sistemi merkezi yönetime dayalıdır (Kerimoğlu, 2019). Birinci ve ikinci sınıfların ögretim programında yer alan Disiplinli Hayat, Mutlu Hayat ve Hayat Bilgisi derslerinde gündelik ve akademik hayata dair bilgiler yer almaktadır. Bu derslerde çevreyi, hayvanları, bitkileri tanıma gibi temalar bulunmaktadır (Öztürk vd., 2016). Güney Kore'de verilen İlkokul Etik Eğitimi dersinde evrensel ahlaki değerler adı altında doğayı korumak, çevreyi koruma, bitkileri ve hayvanları sevmek gibi konular yer almaktadır (Öztürk vd., 2016). Güney Kore hükümeti tarafından Sürdürülebilirlik için Ulusal Strateji ve Eylem Planı hazırlanmıştır. 2008 yılından beri Yeşil Büyüme'ye dâhil olan Güney Kore, eğitimde de bu konuya yönelik düzenlemeler yapmıştır (Ahi \& Kahriman Pamuk, 2019).

\subsection{Bhutan'da Çevre Ë̆itimi Politikaları}

Bhutan'da çevre eğitimi doğal kaynakları koruyarak dünyaya sayg1 duymayı hedeflemektedir. Bu amaçla kurulan Yeşil Okullarda (Green School) doğal ortam özellikleri, çeşitli kavramları gerçek yaşam deneyimleriyle öğretmek için kullanılmaktadır. Okul tüm ögrencileri sürece dâhil ederek öğrenme ve sorumluluk alma düzeylerinde dayanışma kavramını oluşturmaktadır. $\mathrm{Bu}$ yaklaşım öğrencilerde vatandaşlık bilincini yerleştirerek çevreyi koruma konusunda toplumsal hareket etmeyi öğretmektedir. İdeal bir Yeşil Okul ekolojik olarak sürdürülebilir bir toplumun küçük bir örneğidir. Çevre eğitimi tüm akademik disiplinlerin içinde verilmektedir. Okul toplumdan izole değil, toplumun bir parçası olarak görülmektedir. Bhutan'ın sürdürülebilir kalkınmayı toplum mutluluğu ve refahıyla bütünleştirmesi Yeşil Okul uygulamasının temelini oluşturmaktadır. Eğitim, Bilim ve Spor Bakanlığı'yla ve Çevre Bakanlığı'nın ortak çabasıyla sürdürülebilir kalkınmayı desteklemek için 2005 yılında Environmental Comittee for Education (Eğitim için Çevre Komitesi) kurulmuştur (Chandran et al, 2017). 
1518 Ali Ekber Gülersoy - Hilal Yener - Tuğçe Turgut - Dilay Melis Özşahin - Deniz Anter...

\subsection{Malezya'da Çevre Ĕ̈itimi Politikaları}

Malezya'da genç nesli eğitmek ve genç nesilde farkındalık yaratmak için Sürdürülebilir Tüketim ve Üretim için Eğitim (ESCP) programı tanıtılmıştır. Bu müfredat Green Growth olarak adlandırılan sürdürülebilir kalkınma politikasını desteklemek için tasarlanmıştır. Daha az kaynakla daha çok üretim bakış açısını yeni nesilde oluşturmak adına ortaokul için geliştirilen bu müfredat modelinde sekiz ana başlık bulunmaktadır (EPU, 2016). Bunlar; tasarlanmış öğrenme alanları, istendik davranış-hedefler ve sonuç temelli eğitim yöntemiyle kurgulanmıştır. Sürdürülebilir kalkınma hedeflerine uygun olarak belirlenen hedefler bilgi, beceri ve tutum kazandırma üzerine planlanmıştır. Müfredatın hedefleri:

-Sürdürülebilir Kalkınma Hedeflerinin (SKH) üç ana temeli olan sosyal hayat, çevre ve ekonomi üzerine konumlandırılmıştır.

-Hayat kalitesini artırma amaçlanmıştır.

-SKH uygulamaları yoluyla günlük yaşamda değişiklikler meydana getirilmelidir.

-Günlük tüketim alışkanlıkları, daha çok kaynak ve daha az atık oluşturmak adına değiştirilmelidir (Chandran et al., 2017).

\subsection{Endonezya'da Çevre Eğitimi Politikaları}

Endonezya'da sürdürülebilirlik eğitimi, Sürdürülebilir Üretim ve Tüketim için Eğitim (ESC) olarak adlandırılmaktadır. Bilgi, beceri ve değer kazandırmayı amaçlayan bu sistem bireysel ve toplumsal sürdürülebilir tüketim davranışları kazandırmayı hedeflemektedir. Bölgesel ve küresel düzeyde sürdürülebilirliğe olumlu etkiler yapmak amacıyla insanların satın alma davranışlarına etki edecek bilinçlenmenin sağlanmasına odaklanılmıştır. Eğitim sorumluluğunu sadece eğitim kurumları ve öğretmenlerin değil, gazeteciler, çevresel ve sosyal konulara duyarlı yazarlar, TV ve radyo yapımcıları gibi çeşitli alanlardaki kişilerin üstlenmesi gerektiği savunulmaktadır. Endonezya'daki ESC (Sürdürülebilir Kalkınma Eğitimi) genç neslin, çevre sorunlarının tüketim alışkanlıklarıyla ilişkisini idrak etmesi toplumsal hayata ve çevreye duyarlı bireyler haline gelmesini hedeflemektedir (Chandran et al., 2017).

\subsection{Filipinler'de Çevre Eğitimi Politikaları}

9512 sayılı Cumhuriyet Yasası ve 2008 Ulusal Çevre Farkındalı̆̆ ve Eğitimi Yasası, politik çerçeveyi eğitim sistemine uygulamak amacıyla çıkarılmıştır. RA9512 yasası, çevre eğitimini kurumlar arası ve çok sektörel bir yaklaşımla teşvik etmeyi amaçlamaktadır. Sürdürülebilir Kalkınma Eğitimi çevre eğitiminin bir parçası olarak uygulanmaktadır. 9512 sayılı yasa temel alınarak 2009'da DNR Çevre Eğitimi Komitesi kurulmuştur. DNR Çevre ve Doğal Kaynaklar Eğitim Departmanı, Yüksek Öğretim Departmanı, Bilim ve Teknik Departmanı gibi çevre ile ilgili kurumların koordinasyonunu sağlamaktadır. Temiz Hava Politikası, İklim Değişikliği Politikası, Nükleer Atık Politikası gibi politikalar ilkokul, ortaokul ve lise müfredatına çevre farkındalığı oluşturma amacıyla eklenmiştir. Hedefler için okulların çok önemli bir araç olduğunu belirten DNR Bürosu Başkanlığı Sürdürülebilir ve Çevre Dostu Okullar Projesi'ni başlatmıştır. Sürdürülebilir kalkınma eğitimi çevre ve sosyo-kültürel üzerine planlanmaktadır. Kendi kültürüne, diğer kültürlere, geçmişe ve geleceğe, gezegene saygıll bireyler yetiştirmek amaçlanmaktadır. Çevre eğitiminin tüm seviyelerde (örgün eğitim, yaygın eğitim, okul öncesi, teknik eğitim, kamu ve özel sektör, okul dışı gençlik kursları gibi) uygulanması planlanmaktadır. Çevre eğitimi çevre ile ilgili kavram öğretimi, çevre tahribatının doğal kaynaklara ve insan yaşamına etkisi, vatandaşın çevreye karşı sorumlulukları, doğayı korumanın ve tahribatları onarmanın değeri ve sürdürülebilirlikle bağlantısını kapsamaktadır. Filipinler'in çevre eğitimi çevre kavramı üzerine oturtulmuştur. Çevre; doğal çevre, sosyo-kültürel çevre ve inşa edilen çevre olmak üzere üç bölüme ayrılmıştır. Bu üç bölüm üzerine sürdürülebilirlik amaçları yerleştirilmiştir. Sürdürülebilir bir ulus hedeflenmektedir. Çevre eğitimi sadece sürdürülebilirliği amaçlamaz, insan 
ve doğa arasındaki uyumu destekleyen kültürel gelişime de önem verir. Birlik duygusu, milliyetçilik ve vatanseverlik bilinci veren kültür eğitimi de çevre eğitiminin bir parçası olarak görülür. Green Hearth olarak adlandırılan çevre eğitimi genel teması, üç değer üzerine inşa edilmiştir; işbirliği, sağduyu ve empati. Ulusal sorumlulukların küresel sorumluluklarla birleştiği bir tutum kazandırmak amaçlanmaktadır. 2023-2030 hedeflerini, sürdürülebilirlik tabanlı çevre eğitimini tüm öğretim seviyelerinin \%50'sine uygulamak, sürdürülebilir kalkınmayı ilkokul, ortaokul, lise ve yükseköğretimde zorunlu ders olarak müfredata eklemek, okul içi, bölgesel, ulusal proje yarışmaları düzenlemek, kılavuz kitaplar yayınlamak, öğretmenler için ulusal forumlar düzenlemek, hayat boyu öğrenmeyi desteklemek oluşturmaktadır. 2031-2040 hedeflerini ise; öğretmen ve öğrenciler için eğitim atölyeleri oluşturmak, ulusal ve uluslararası yeni ortaklıklar geliştirme, yükseköğretim öğrencileri için sürdürülebilirlik ve sosyo-kültürel değer tabanlı stajlar oluşturma, yeni kalkınma planları için okul düzeyinde ve topluluk düzeyinde zorunlu projeler yapma, sürdürülebilir kalkınma eğitimini (SKE) okulların \%100'ünde uygulama, müfredatı SKE'ne uygun kurgulama olarak belirlemişlerdir (Chandran et al., 2017).

\subsection{Hong Kong'da Çevre Eğitimi Politikaları}

Nüfusu hızlı artış gösteren ve güçlü bir sanayi ülkesine dönüşen Hong Kong'da çevre farkındalığ 1 gelişmiş ve çevre sorumluluğuna sahip bir toplum oluşturmak hedeflenmektedir. 1989 tarihinden itibaren Hong Kong Hükümeti çevre eğitimiyle ilgilenmeye başlamış, 1992 yılında hem resmi okullarda hem sivil toplum kuruluşlarında uygulanacak çevre eğitimi için kılavuz hazırlamıştır. Teknoloji, fen, sosyal, ahlak, estetik, dilbilim, sağlık, matematik, sanat, Çin Tarihi gibi birçok disipline çevre eğitimini entegre etmeyi amaçlayan bu kılavuz örgün ve yaygın eğitimi ve çevre dostu aktiviteleri kapsamaktadır. Konu temelli bir çevre eğitimi sunan Hong-Kong'da müfredatla uygulamalar arasında boşluklar bulunduğu saptanmıştır. Öğretmen eğitimi, çevre eğitimi ve hizmet içi eğitim müfredatlarında reform yapılması, sürdürülebilir kalkınma eğitimine yönelik değişiklikler yapılması gerekmektedir (Lee, 1997). Hong Kong'da son on yılda özel sektörün de sürdürülebilir kalkınma eğitimine önem verdiği HSBC gibi büyük çaplı kuruluşların hizmet içi eğitimler düzenlediği bilinmektedir (Law et al., 2017).

\subsection{9. Çin Halk Cumhuriyeti'nde Çevre Eğitimi Politikaları}

Çin Halk Cumhuriyeti'nde çevre eğitimi, erken okul çağından yükseköğretime kadar her aşamada verilmektedir, ancak ağırlık yükseköğretim kurumlarındaki çevre eğitimine verilmiştir. Bu aşamada da çevre eğitiminin iki bölümde düzenlendiği görülmektedir. Bahsi geçen düzenlemelerden birincisi, çevre eğitimi üzerine uzmanların eğitilmesine yönelikken ikincisi ülkede topluma yönelik verilen eğitimlerdir. Uzmanlara özgü eğitimler, yükseköğretim kurumlarında çevre ve ekoloji alanlarında uzman ya da kendi mesleklerinde çevreye ilişkin hususlarda çalışacak kişiler yetiştirmeyi amaçlamıştır (Ahi \& Kahriman Pamuk, 2019; Xiaoyun \& Qiang, 2010).

Temel eğitim seviyesine bakılırsa verilen tüm ders içerikleri çevre ile bağdaştırılmalıdır. 2013'te Çin Eğitim Bakanlığı erken okul çağını da kapsamak kaydı ile tüm aşamalarda 'tasarruf eğitimi' davetinde bulunan bir doküman yayınlamıştır (Ahi \& Kahriman Pamuk, 2019; Zhou et al., 2016). Bununla birlikte ilkokullarda ve ortaokullarda seçmeli çevre eğitimi dersleri ile öğrencilerin çevreye olan ilgisinin arttırılması amaçlanmaktadır. Öğrencilere doğada yapılan aktiviteler ve topraktan nasıl yararlanacaklarını anlatan etkinlikler hazırlanıp yaptırılmaktadır. Yine bu okullarda çevreye ilişkin öğrenci gruplarının oluşturulması ve bu grupların topluluğa dönüştürülmesine de destek verilmektedir (Huaixin, 2003; Ahi \& Kahriman Pamuk, 2019). Okul öncesindeki öğrenciler için ise 1952'nin ilk aylarında Çin Ulusal Eğitim Bakanlı̆̆ı'nca bir yönetmelik yayınlanmıştır. Sözü edilen yönetmelikte, okul öncesi ve erken çocukluk dönemindeki çocuklara çevre eğitimi öğretim programı içine doğal çevreyi tanımanın ve bilmenin bir kazanım olarak ilave edilmesi tavsiye edilmiştir (Zhou et al, 2016). 
Çin 1978'den itibaren son derece hızlı bir ekonomik büyüme göstermiş, bu durum çevre sorunlarına yol açmıştır. Çin doğa tahribatı, doğal kaynakların tükenmesi, iklim değişikliği gibi sorunlarla karşı karşıyadır. Çin'in ekonomik büyüme ve sürdürülebilir kalkınma arasında bir denge kurması gerekmektedir.

1992 Rio Konferansı'ndan sonra küresel ve yerel politikalar, sürdürülebilir kalkınma kavramı çevre eğitimine entegre edilmiştir. Nüfus, çevre ve kalkınma üzerine 1994'te yayınlanan China's Agenda 21 (Çin'in Gündem 21'i) sürdürülebilir kalkınma kavramını ilköğretimden yükseköğretime kadar dâhil etmeyi amaçlamaktadır. 1996'da yayınlanan Çevresel İletişim ve Eğitim için Ulusal Eylem Rehberi ile 1996-2000 yılları arası planlanmıştır. 2000 yılı itibariyle yeşil bir müfredatı uygulayan Yeşil Okul Programı'nın tüm ülkede yaygınlaştırılması hedeflenmiştir. Çevre üzerine çalışmalar yapan birçok STK 1990'larda kurulmuştur. Akademik yayınlar yapan Çevre Eğitimi Dergisi 1995 'te yayın hayatına başlamıştır. 2002 yılından itibaren çevre eğitimi her düzeyde ve her alanda gelişme göstermiş, sürdürülebilir kalkınma kavramı tüm belgelere girmeye başlamıştır ve sürdürülebilir kalkınma faaliyetleri ülke geneline yayılmıştır. 1973 ile 1983 yılları arasındaki çevre eğitiminin ilk evrelerinde çevreyi koruma teknolojilerine odaklanılmış, yükseköğretim kurumları çevre eğitimi üzerine akademik programlar oluşturmuş ve yasal belgeler hazırlamıştır. 1973'te düzenlenen çevreyi koruma üzerine yapılan ilk ulusal toplantıda çevre eğitiminin de temelleri atılmıştır. 1979 'da bazı ilkokul ve ortaokullarda çevre eğitimi üzerine pilot uygulamalar yapılması kararı verilmiştir. 1983 ile 1992 arasında çevreyi koruma anlayışı kurumsallaştırılmış, halkın ve hükümet yetkililerinin çevre bilincini arttırmaya yönelik çalışmalar yapılmıştır. 1985 yılında ilkokul ve ortaokullar için çevre eğitimi üzerine yapılan seminer Çevreyi Koruma Departmanıyla Eğitim Departmanını işbirliğine yönlendirmiştir (Chinese Society for Environmental Sciences, 2008; Tian \& Wang, 2016). China's Agenda 21, The White Paper on Population adlı belgeler 1994'te yayınlanmış, The White Paper adlı belgede sürdürülebilir kalkınma hedeflerinin ilkokuldan yükseköğretime kadar her seviyede olması gerektiği vurgulanmıştır (Chen \& Sun, 2009; Tian \& Wang, 2016). Ulusal Çevre İletişimi ve Eğitimi Rehberi (1996-2010) 1996'da yayınlanmış, 2000 yılı itibariyle Green School programının tüm ülkede yaygınlaştırılması; yeşil müfredat, yeşil yönetim gibi kriterleri sağlayan okullara sertifika verilmesi kararı alınmıştır. 2003'te yayınlanan NSD (The Notion of Scientific Development) ekolojik bir medeniyet ve yaşam tarzı için çevre eğitiminin önemini vurgulamıştır. Bu belgenin uygulama aşamasında çevreye yönelik bilgi, tutum ve değerlerin bulunduğu yeni zorunlu ilkokul ve ortaokul çevre eğitimi müfredatı belirlenmiştir. 2011'de Ulusal Çevre İletişimi ve Eğitimi için Eylem Rehberi (2011-2015) yayınlanmış, çevre bilincini güçlendirmek, ekolojik hayatı desteklemenin önemi vurgulanmıştır. Çin'de 1990'lardan itibaren çevre ile ilgili STK'lar faaliyet göstermektedir ve çevre eğitimine yönelik akademik dergiler yayınlanmaktadır (Tian \& Wang, 2016). Çin'deki çevre tahribatını kontrol altına almak için çevre mevzuatında değişiklikler yapılmış ve nüfus kontrol önlemleri uygulanmıştır. $\mathrm{Bu}$ uygulamaların başarısı Çin halkının çevre farkındalığ 1 ve sorumluluk alma düzeyiyle birebir orantılıdır. Çin'in çevre politikası ile çevre eğitimi politikası paralellik göstermektedir. 1970'den itibaren hem fiziki hem de sosyal çevreye odaklanan çevre eğitimi çevre sorumluluğu oluşturmaya odaklıdır. 1981'de Tianjin kentinde düzenlenen Ulusal Çevre Eğitimi Kongresi'nde özellikle yetişkin eğitiminin güçlendirilmesine dair bir karar alınmıştır (Lee \& Tilbury, 1998; State Environmental Protection Bureau Propaganda and Education, 1991). 1985 ve 1989'da Ulusal İlkokul ve Ortaokul Çevre Eğitimi seminerleri düzenlenerek bu alanda uzman eğitmenler yetiştirilmiştir. China Environment News (Hongguo Huangjing Bao), The Newspaper Of The State Committee of Environmental Protection adl1 gazeteler yayınlanmıştır. 1994'te yayınlanan Eğitim Komisyonu Raporunda; doğa bilimleri, sosyal bilgiler, fizik, kimya, biyoloji, coğrafya gibi derslerde çevre eğitimi konularının işlenmesi kararı alınmıştır. 1994'te Ulusal Çevre Eğitimi Kongresi'nde çevre bilincini tüm ulusa yaymak, mevcut çevre problemlerini çözmek ve olası çevre sorunlarını önlemek için genç nesle doğa sevgisi ve çevre farkındalığı aşılamanın gerekli olduğu belirtilmiştir. 1992'den sonra sürdürülebilir kalkınma 
örgün eğitim müfredatlarına dâhil edilmiştir. Teorik ve teknik merkezli bir eğitim modelinin çevreyi koruma farkındalı̆g 1 oluşturmakla çeliştiği, eğitim politikalarında düzenlemeler yapılması gerektiği saptanmıştır (Lee \& Tilbury, 1998).

\subsection{0. Özbekistan'da Çevre Ĕ̈itimi Politikaları}

Özbekistan'da birçok faaliyeti denetlemek ve düzenlemek amacıyla Tabiatı Koruma Komisyonu kurulmuştur. Hükümet 5 yıl boyunca yürürlükte olacak olan ve ülke için faydalı bir programı yapmaya çalışmaktadır. Bu proje 2018 yılına kadar devam etmiş ve aynı zamanda 68 farklı projeyi kapsamıştır. Aslında ülkenin çevre politikasına olan yaklaşımları kendilerine hastır. Bunun nedeni ise günlük yaşantıda çevrenin büyük bir payının olmasıdır. Özbekistan için çevrenin büyük önemi olduğundan halk ekolojik siyasetin katılımcısıdır. Özbekistan çevre politikasının ağırlığı daha çok sanayi, tarım ve turizm üzerindedir (Aliyev, 2013).

\subsection{Kazakistan'da Çevre Ĕ̈itimi Politikaları}

Ülkedeki çevre politikasında üç asıl amaç bulunmaktadır. Bunlar; çevrenin kirliliğinin azaltılması ve önlenmesi, doğal kaynakların aktif kullanımı ve yenilenebilir enerji kaynaklarından olumlu şekilde yararlanılmasıdır. $\mathrm{Bu}$ hedefleri ekolojik güvenliği sağlamak amacıyla oluşturmuşlardır. Devletçe yürütülen çevre politikası 2030 yılına kadar gıdaların saflaştırılması, çevrenin daha temiz olması ve çevre dengesinin korunmasını hedeflemektedir. "Strateji-2030" çevre politikası belgesi 1998 'de uygulanmaya başlanmış ve ilk aşamasını başarıyla tamamlamıştır. Fakat ilk adımın başarılı olmasına rağmen Kazakistan'da çevre kirliliği engellenememiştir (Aliyev, 2013). Ciddi ekolojik sorunlarla yüz yüze kalan Kazakistan'da çevre eğitimi gönüllü sivil kuruluşlar tarafindan verilmekte olup, devlet bu kurumların faaliyetlerini kolaylaştırmak için destek vermektedir (Soltys \& Orynbassarova, 2013).

\subsection{Türkmenistan'da Çevre Eğitimi Politikaları}

Türkmenistan kimya sanayisi ile ilgili hammaddeleri barındırmaktadır. Ancak yabancı yatırımcılar çevre koşullarını ve altyapının eksikliği nedeniyle Türkmenistan'a yatırım yapmamaktadırlar. Ülke tarihinde ilk kez çevrenin korunması ile ilgili tüm ülkeyi dâhil eden bir proje oluşturulmuştur. Proje 2015'e kadar çevreyi ve tabii kaynakların korunmasını sağlamayı hedeflemiştir. Çevre politikasının uygulanması Türkmenistan'ın kalkınmasına ve Orta Asya'da ülkeleri arasında ön plana çıkmasına neden olacaktır. Bu çerçevede Orta Asya'da çevreyi koruma hedef alınmış ve Aşkabad Konvansiyonu imzalanmıştır (Aliyev, 2013).

\subsection{Azerbaycan'da Çevre Eğitimi Politikaları}

Azerbaycan'da çevre sorunları gittikçe artmış ve bu durum ülkeyi farklı bir çevre politikası izlemeye yönlendirmiştir. Ülke daha çok önleyici tedbir kararlarına yönelmiştir. Çevre politikaları gelişmeye devam etmektedir. Bununla beraber çevreyi koruyup ve geliştirmek için ülkede çeşitli kurum ve kuruluşların kurulması gerekmektedir (Aliyev, 2013). Toplumda çevre bilinci kazandırmak ve çevreyi korumak amacıyla Birleşmiş Milletler Örgütü Genel Kurulu'nun 15 Aralık 1972 tarihli kararına göre her y1l 5 Haziran 'Uluslararası Çevrenin Korunması" günü olarak kabul edilmiştir. Çevrenin korunması için yapılan başka bir faaliyet ise Milli Faaliyet Tasarısıdır (Kadimbeyli, 2014). Azerbaycan Eğitim Bakanlığı, eğitim sisteminin yönetilmesinde rol oynamakta ve eğitim alanında devlet politikasına katkıda bulunmaktadır. Eğitim Bakanlığı bünyesinde oluşturulan Devlet Yüksek Eksperi Komisyonu, eğitim bakanı kadar yetkiye sahiptir (Ergün, 1997). Azerbaycan Cumhurbaşkanı'nın 27 Ocak 2003 tarihli "Halkın ekolojiyi öğrenmesi ve bilgilendirilmesi hakkında" bildirisine bağlı olarak lise ve üniversitelerde çevrenin korunması ile ilgili konulara yer verilmiştir (Kadimbeyli, 2014). Çevrenin korunması ve doğaya zarar vermeden çevreden verimli yararlanılması konusunda toplumun bilinçlendirilmesi amacıyla eğitim programları hazırlanmaktadır. Eğitim reformu çevre eğitimini de etkilemiştir. Çevre ile ilgili 
çağdaş düzenlemeler kabul edilmesine rağmen bu yasaların benimsenmesi ve uygulanmasında belirli bazı aksaklıklar bulunmaktadır (Zengin, 2008).

\subsection{Kanada'da Çevre Ĕ̈itimi Politikaları}

Kanada çevre eğitimi hususunda seviye bakımından ilerlemiş ülkelerden biridir. 1960'lı senelerden başlayarak çevre ve çevre eğitimi konuları Kanada eğitim sistemi içinde yer almıştır. Kanada'da çevre eğitimi içeriğinde çevre problemlerine toplumun dikkatini çekme, doğa üzerinde araştırmalar yapma isteği uyandırma, doğa ile tarihi harmanlayarak doğayı korumaya yönelik eğitimler verme bulunmaktadır (Ahi \& Kahriman Pamuk, 2019; Hart, 2003). 1970'li senelerin ilk zamanlarında, Kanada'da bulunan 41 üniversitenin yalnızca 6 tanesinde çevre ile ilgili çalışmalar ve projeler yapılmış ve bu üniversitelerin eğitim fakültelerindeki öğretmen adaylarına çevre eğitimi verilmiştir (Lin, 2002; Rioux, 1973).

Kanada'da bilhassa okul öncesi çocuklarına ve aile fertlerine yönelik çevre eğitimi etkinliklerinde artış vardır. Alternatif okul yaklaşımını benimseyen çoğu Orman Okulu ve doğa merkezli okul, erken çocukluk dönemindeki çocuklara yönelik çalışmaktadır. Bu okulların dikkat çeken özellikleri ise kentin ortasında, bu çocukların doğa ile etkileşimde bulunmalarına imkân vermesidir. Bahsi geçen okullarda öğrencilerin oynadıkları oyuncaklar doğal malzemelerden yapılmıştır. İlaveten, katkısız gıdalarla yapılan ev yapımı yiyeceklerle sağlıklı olarak beslenmektedirler (Ahi \& Kahriman Pamuk, 2019; Ravensbergen, 2012).

1945-1995 yılları arasında yani savaştan sonra çevrenin korunmasına yönelik politikalar uygulanmıştır. 1995 yılında ilerici muhafazakâr parti hükümet kurunca çevre ile ilgili yasalar ve uygulamalar neredeyse tamamen kaldırılmıştır (Winfield \& Jenish, 1999). Doğal kaynak yönetimine dair tüm yasalar ve bütçelerin iptal olmasının yanında eğitim sistemi de bu değişiklikten olumsuz yönde etkilenmiştir. 1998'de yayınlanan yeni müfredatta çevre eğitimi içeriği 7. sınıf hariç \%5'in altında bırakılmıştır. 1999 yılında kabul edilen ortaöğretim müfredatında ise önceden var olan Çevre Bilimleri dersi kaldırılmıştır. Bu gelişmelerle birlikte takip eden 10 senede çevre eğitimi içeriği tamamen yok edilmiştir. Çevre Bakanlığı'nın Çevre Koruma Yönetmeliği hükümlerine (EBR) dâhil olmasıyla Ontario Eğitim Bakanlığı çevre eğitimi politikası geliştirmiştir (ATST: Acting Today, Shaping Tomorrow). 2009 yılında Ontario Eğitim Bakanlığı'nın kendi çevre eğitimi politikası çerçevesini belirlemesiyle (Karrow \& Fazio, 2015; Ontario Ministry of Education, 2009) kamu okullarında çevre eğitimi 15 y1l sonra yeniden uygulanmaya başlamıştır. Öğretmenler ATST çerçevesinde kalmak şartıyla öğretimi uygulamada özerktirler. ATST politikasına göre çevre eğitimi bilgi, beceri edindirme ve olumlu tutum geliştirme amacını taşır. Eğitimcilerin disiplinler arası ve bütünleştirici bir eğitim uygulayarak gerekli çevre okur-yazarlığını vermesi beklenmektedir. ATST politikasının çevre eğitimi alanında olumlu bir etki yarattığı belirtilmektedir.

Kanada'da çevre eğitimi bireysel girişimlerle başlamıştır. Sonradan hükümet politikalarında ve okul yönetimi politikalarında yer almasıyla okul sistemine yayılmıştır. Bu girişimleri başlatanların uluslararası çevre konferanslarından etkilendiği söylenebilir. Birçok ilde NAEE'ye bağlı kuruluşlar oluşturulmuştur. Project Wild ve Project Learning Tree adlı ABD menşeli interaktif projeler Kanada'da da uygulanmıştır. $\mathrm{Bu}$ projelerde il düzeyinde iletişimi sağlayan koordinatörler vardır ve sınıf içi faaliyetlerden öğretmenler sorumludur. 1983 yılında yayımlanan Alberta Çevre Eğitimi El Kitabı öğretmenler, hükümet görevlileri, iş insanları ve Alberta Çevre ve Açık Hava Eğitimi üyelerinin katılımıyla oluşturulmuştur. Belgrad Şartı'na atıfta bulunarak hazırlanan bu kitap disiplinler arası hedef odaklı öğretim durumlarını içerir. Saskatchewan'da altı alana dayalı bir müfredat geliştirilmiştir. Bu alanların birisi olan Fen eğitimi bölümüne çevre okur-yazarlığı, bilimsel okuryazarlık hedefinin içine alt hedef olarak eklenmiştir. Alberta ve Saskatchewan illerinde çevre eğitimi müfredatı oluşturmuş, öğretmenler eğitim materyali geliştirmiştir. Alberta Çevre Eğitimi El Kitabı disiplinler arası özellikte, sosyal açıdan çevreyi inceleyen bir çevre eğitimi yaklaşımı sunmaktadır. Belgrad Şartı'nın (Belgrad Charter) 
hedeflerine göre hazırlanan bu kılavuzlar yerel şartlar ve uygulama koşulları dikkate alınmadan hazırlanmıştır. Kanada son 25 senede çevre eğitimi alanındaki uluslararası gelişmelerden etkilenmektedir. Belgrad Şartı (1975), Tiflis Bildirgesi (1977), UNESCO-UNEP gibi belgeler temel alınarak hazırlanan eyalet müfredatlarının saha uygulamaları Amerikan benzeri uygulamalarla yapılmaktadır. NAAEE'yi (Kuzey Amerika Çevre Eğitimi Derneği) örnek alarak hazırlanan saha uygulamaları bu duruma örnek olarak verilebilir. Teorikte küresel bakış açısını benimsemeye çalışan Kanada eğitim sistemi pratikte ABD benzeri uygulamalara yöneldiği için çevre eğitiminde de hala bazı ikilemler ve sorunlar barındırmaktadır (Hart, 1990).

Kanada'nın uyguladığı Beş Yıllık Çevre Planı'nda planlama kapsamında yapılacak işler, kamuoyunu bilinçlendirme ve halkın çevreyle ilgili kararlara katılımını hedefleyen "çevresel vatandaşl1k" kavramları çerçevesinde belirlenmektedir (Karataş \& Karabağ, 2013).

\subsection{Amerika Birleşik Devletleri’nde Çevre Eğitimi Politikaları}

ABD'de 1935 yılında National Association of The United States okullarının çevre eğitimi etkinlikleri yapmış, 1946'da ise Wisconsin Üniversitesinde çevreyi koruma alanında bölüm açılması önerilmiştir (McCrea, 2006). 1970’te çıkarttıkları Federal Çevre Kalitesi Eğitim Yasası ile ABD'de çevre eğitiminin başladığı varsayılmaktadır. Yasanın hedefinde çevreyi koruma altına almak ve çevre niteliğini yükseltmek vardır. Eğitim aslında bu görevi tamamlamak adına bir amaç yerine araç olarak görülebilmektedir. Ancak bu alana ülke fonundan yetersiz miktarda para ayrılması çevre eğitiminin dar bir alanda kalmasına sebep olmuştur. 1970'lerdeki federal destek 1980'lere gelindiğinde kaybolmuştur. Genellikle çoğu eyaletin eğitim birimleri federal hükümeti izlemişler ve bu da çevre eğitiminin gölgede kalmasına sebep olmuştur (Öner \& Arslan, 2005).

Amerika Birleşik Devletleri'nde Çevre Koruma Ajansı (EPA) çevre eğitimini desteklemede etkin rol oynamıştır. Bu koruma ajansı çevre koşullarının daha verimli olması, doğadaki kaynakların korunması ve yine çevrenin korunması ile ilgili plan-programların düzenlemesi gibi görevleri bünyesinde barındırmaktadır. UNESCO'nun eğitim programı geliştirme stratejilerinin doğrultusunda $\mathrm{ABD}$ kendi eğitim programlarına ekleme ve güncelleme yapmıştır. 1990'lı yıllar ve sonrasında çevre eğitimi yaklaşımı biraz da sürdürülebilir kalkınma eğitimine dönmüştür. Okul öncesi eğitimden yükseköğrenime kadar eğitimin tüm aşamalarında yapılan olumlu yöndeki değişiklikler eğitim programlarına yerleştirilmeye çalışılmıştır (Ahi \& Kahriman Pamuk, 2019).

Çevre politikasına dair ilk örnekler ABD'nin kamu politikaları içerisinde ortaya çıkmıştır (Kaypak, 2013). Çevre Koruma Ajansı (EPA) Amerika'da var olan çevre eğitiminin ilerlemesinde çok büyük bir paya sahiptir. Ajans, ulusal çevre eğitimi standartlarını belirler. Buradaki temel amaç, kitlenin çevre okuryazarlı̆̆ durumuna pozitif yönde bir katkıda bulunmaktır. Ajans, Eğitim Bakanlığ1 ve Eğitim Federal Teşkilat Komitesi ile birlikte hareket ederek küçük yaşlardan başlayarak yetişkinlik dönemine kadar çevre eğitimi ile alakalı materyaller ve programlar geliştirmektedir, aynı zamanda çevre ile alakalı seminer, konferans vb. etkinlikler düzenlemektedir. Özellikle 1970'li yıllardan sonra Amerika'da aktif bir çevre eğitimi çalışması yapılmıştır. 1990'lı yıllardan sonra bu çalışmaların adı sürdürülebilirlik için çevre eğitimi olarak değişim göstermiştir. Eğitim kurumlarının her seviyesinde bu yenilemeler eğitim programına entegre edilmeye çalışılmıştır (Ahi \& Kahriman Pamuk, 2019).

\subsection{Ekvador'da Çevre Eğitimi Politikaları}

Ekvador çevre eğitiminde çoğu ülkeden daha farklı bir yöntem izlemiştir. Birçok ülke çevre eğitimini hükümet merkezli yürütürken, Ekvador bu durumu STK'lar aracılığı ile yürütmüştür. Ekvador hükümeti bir çevre eğitimi programı hazırlamak istemiş ve çağrıda bulunmuştur. Bu davete cevap veren kurum ise Ekvador'da bulunan OİKOS olmuştur. Kuruluş ülkenin tamamını kapsayan bir program hazırlamıştır. Programın genel olarak amacı halkın refah seviyesini arttırmak iken aynı zamanda çevre sorunlarının nedenleri ve çözümleri, temiz içme suyu 
gibi konular halka uzmanlar aracılığı ile anlatılmış ve bu proje başarıya ulaşmıştır (Ahi \& Kahriman Pamuk, 2019; Encalada, 2003). Bir diğer çalışma ise çevre eğitiminin geniş halk kitlelerinde yaygınlaşmasını amaçlamış ve "Çevreye Yönelik İletişim ve Eğitim Planı" ismi ile yürütülmüştür. Buradaki amaç geniş halk kitlelerini çevre sorunları gibi konularda bilinçlendirmektir. Ayrıca erken çocukluk döneminde çevre eğitimi ile ilgili konulara yer verildiği ve eğitim dönemi boyunca ekosistemler, toprak ve su vb. konulara yer verildiği bilinmektedir (Ahi \& Kahriman Pamuk, 2019; Viteri et al., 2013).

\subsection{Brezilya’da Çevre Ĕ̈itimi Politikaları}

Çevre eğitiminde kurumsallaşma politikası 1980'lerde başlamıştır. 1981'de onaylanan Ulusal Çevre Politikasında çevre eğitiminin tüm eğitim seviyelerine yerleştirilmesine karar verilmiş̧ir. 1988'de kabul edilen anayasada çevre eğitiminin önemi vurgulanmıştır. Bu anayasada çevre eğitimi kişisel hak olarak tanımlanmıştır. 1994 yılında sürdürülebilir toplum ve küresel sorumluluk uyarınca Ulusal Çevre Eğitimi Programı (Pro-NEA) oluşturulmuş, 1999 yılında yayınlanan Ulusal Eğitim Politikasında çevre eğitiminin ulusal eğitimin temel ve kalıcı bir bileşeni olması gerektiği ve tüm seviyelere uygulanması kararlaştırılmıştır. Brezilya Eğitim Bakanlığ tarafından 2001 yılında çıkarılan "Eylemdeki Parametreler Programı" tüm eğitim seviyeleri için gerekli bir tema olarak çevre eğitimini içermektedir. 2002 yılında hükümet, komisyon tarafından düzenlenen Brezilya Gündemi 21'i başlatmıştır. Sürdürülebilir kalkınma politikaları Çevre Bakanlığı tarafından desteklenmektedir. 2010'lara gelindiğinde, çevre eğitimini düzenlemek için zaten iyi yapılandırılmış bir yasal çerçeve vardır ve çevre eğitimi için kamu politikaları geliştirilmiştir. 2012 yılında, Ulusal Eğitim Konseyi (Conselho Nacional de Educação-CNE) Çevre Eğitimi için Ulusal Müfredat Yönergeleri'ni detaylandırmıştır. 2013 yılında, Eğitim Bakanlığı tarafından Sürdürülebilir Okulları desteklemeyi amaçlayan belirli bir bölümle Okulda Doğrudan Para Programı başlatılmıştır. Bu program, devlet okullarında çevresel sürdürülebilirliğin geliştirilmesi için finansal destek sunmayı amaçlamaktadır. Sürdürülebilirliğe geçiş sloganı altında, bu program, COM-VIDA adı verilen Çevre ve Yaşam Kalitesi Komitelerini, bu okulların sürdürülebilir eğitimci alanlarına dönüştürülmesinde yerel bir anahtar unsur olarak desteklemektedir. COM-VIDA, sürdürülebilirliğin sosyal ve çevresel eylemlerini teşvik etmenin yanı sıra okul topluluğu ve bölgesi arasında ilişkiler kurmak isteyen tüm okul topluluğunun katılımını geliştirmektedir. 2014 yılında Milli Eğitim Planı 2014-2024 dönemi için onaylanmıştır. Milli Eğitim Planı, Federal Anayasa tarafından güvence altına alınmıştır ve her 10 yılda bir milli eğitim için yönergeler, hedefler ve stratejiler belirlenmektedir. Şu anda Ulusal Eğitim Planı, Ortak Ulusal Müfredat Temeli'nin (CNCB) inşasını ortaya çıkarmaktadır. Bu, Brezilyalı öğrencilerin temel eğitimleri boyunca öğrenmeleri gereken temel bilgi ve becerileri oluşturmay amaçlamaktadır. Eğitim Bakanlığı, CNBC'nin geliştirilmesinden sorumlu kurumdur. 2014 yılında analiz ve öneriler için halkla istişare şeklinde bir ilk sürüm belgesi başlatmıştır. Brezilyalı araştırmacılar ve eğitimciler, çevre eğitimini CNCB'ye dâhil etmişlerdir. $\mathrm{Bu}$ belgede, sürdürülebilirlik bütünleştirici bir tema olarak belirtilmiştir, ancak çevre eğitimine özel bir referans yoktur (Carvalho \& Frizzo, 2016).

\subsection{8. Şili'de Çevre Ĕgitimi Politikası}

Şili'de Çevre Temelleri Yasası'nda (Bases of Environment) vatandaşlık eğitimi, 'biyofiziksel ortamla, kültürle, yaşadığı toplumla uyum sağlayabilecek yeterlilikte bireyler yetiştirmek' olarak tanımlanmıştır (González Gaudiano 1997; 1998; Muñoz-Pedreros, 2014). Çevre eğitimi 1970'lerden itibaren çevre politikalarında yer almasına rağmen, çeşitli eğitim alanlarına girmesi süreci yavaş ilerlemiştir (Muñoz-Pedreros, 2014; Porto Gonçalves, 2006).

1970'lerin sonundan itibaren faaliyet gösteren NGO adlı STK çevre eğitimini yaygın eğitim şeklinde vermektedir. Bu kurum uluslararası çevre derneklerini örnek almıştır. Ancak söz konusu tarihten sonra iktidara gelen Şili hükümetlerinin çevre eğitimi politikaları mevcut değildir (Muñoz-Pedreros, 2014). 1970'lerde yaygın eğitimle verilmeye başlanan çevre eğitimi, 1990'larda 
örgün eğitime dâhil edilmiştir. 1987'den itibaren kongreler, çalıştaylar ve sempozyumlar düzenlenmiş, yükseköğretimde lisans ve yüksek lisans dereceleri verilmiştir (Centro de Análisis de Políticas Públicas, 2013; Ministerio del Medio Ambiente, 2011; Muñoz-Pedreros, 2014; Squella, 2000). Kitle iletişim araçları halkın çevre konusunda bilinçlenmesinde temel kaynaktır (Montero, 2004; Muñoz-Pedreros, 2014). Birçok ilkokul ve ortaokul, çevre eğitimini programlarına dâhil etme eğilimindedir, fakat öğretmenlerde bu alanda yetersizlik bulunmaktadır (Muñoz-Pedreros, 2014).

\subsection{Papua Yeni Gine’de Çevre Eğitimi Politikaları}

Papua Yeni Gine' de çevre koruma uygulamalarını anlatmak için ilkokulları ziyaret eden bir eğitim ekibi bulunmaktadır (Ryan, 2009). Papua Yeni Gine'de çevre eğitimi politikası, topluluk tabanlı grup ve tüm devlet okullarında örgün eğitimin verilmesi şeklinde iki başlık altında incelenebilir (Bakırcı \& Artun, 2011; Ryan, 2009). Dünya bankasının bu ülkelerin çevre projelerine kaynak sağlamasından dolayı programlarında dünya bankasının eğitim modeli dikkate alınmıştır (Bakırcı \& Artun, 2011). Dünya Bankası ve Asya Kalkınma Bankası tarafından sağlanan fonlarla kurulan tarlalarda palmiye yağı üretilmesi için sözleşmeler yapılmıştır. Ancak söz konusu süreç Papua Yeni Gine'de zamanla doğal yapıyı bozmuştur (Ryan, 2009).

\subsection{Avustralya'da Çevre Eğitimi Politikaları}

Avustralya, çevre eğitimine ilişkin dünya genelindeki ilerlemeleri eş zamanlı ve ilgi ile takip eden ülkelerden biridir. Avustralya'da 1970'li senelerden günümüze uluslararası sahada alınan kararları ülkeye uygun olacak biçimde entegre etmekte ve çevre eğitiminin halka ulaşmasında ile en önemli payı üniversiteler almaktadır. Bunun haricinde Avustralya'da resmi kuruluşların dışında kalan ve bağımsız çalışan sivil toplum örgütleri ve ülkece desteklenen programlar çevre eğitimini her vatandaşa ulaştırmayı hedeflemektedir. Aralarından en önemlisi Ulusal İş Bulma, Eğitim ve Yetiştirme Bakanlığı'nın (Commonwealth Department of Employment, Education and Tarining) da desteği ile üniversiteler, bazı sendikalar ve sivil toplum örgütleri ile iş birliği içinde ilerlettiği ortaklık programıdır. Asıl amac1, üniversiteler ve eğitimin tüm aşamaları için çevre eğitimi alanında yetkin öğretmenler yetiştirmek, eğitim programlarına çevre eğitimini dâhil etmek, çevre eğitimini daha aktüel hale getirmek ve çevre alanında iş olanakları yaratmaktır (Ahi \& Kahriman Pamuk, 2019; Robottom, 2003).

Avustralya, 1970'li yıllardan beri uluslararası alanda alınan kararları kendi toplumuna uygun bir şekilde düzenlemektedir. Sivil toplum kuruluşları ve hükümet tarafindan desteklenen bazı programlar çevre eğitiminin yayılmasını ve toplumu bilinçlendirmeyi amaçlamaktadır. Hükümet, çevre politikaları bakımından güncel reformları ve gündemleri takip etmekte ve eğitimcileri desteklemektedir. Avustralya Sürdürülebilir Okullar Girişimi, Avustralya Hükümeti ile iş birliği yaparak Birleşmiş Milletler'in kalkınma planlarındaki stratejilerin uygulanmasına katkı sağlamıştır (Ahi \& Kahraman Pamuk, 2019). Topluluk eğitimi kapsamında Avustralya'nın Tyrol şehrinin Ruette Bölgesi'nde ortaöğretim öğrencilerine, Semt Satış1/Neighbourhood Store Projesi uygulanmıştır. Öğretmen eğitimi amacıyla "Sürdürülebilir Bir Dünya İçin Öğretim" ve "Sürdürülebilir Çevre İçin Öğrenme" programları uygulanmıştır (Okur, 2012).

\section{Dünya'da ve Türkiye'de Çevre Politikalart ile İlgili Belgelerde Çevre Eğitimi}

$\mathrm{Bu}$ bölümde ulusal ve uluslararası düzeydeki belgelerde çevre eğitimine yönelik açıklamalar incelenmiştir.

Ulusal anayasalarda her ülkenin kendine özgü bir tanım yaptığı çevre hakkı, vatandaşlık bilincinin geliştiği tüm bireylere kendi haklarını savunmaları ve geliştirmeleri adına çevreye ve çevre problemlerine yönelik alınacak kararlarda aktif katılımlarını sağlayacak seçenekler sunmaktadır. Çevre hakkı kavramını anlayıp bu hakka sahip çıkmak ve gerektirdiği sorumluluğa uygun davranışlarda bulunmak için çevre farkındalığı ve bilinci kazanmak şarttır. Bu zorunluluk 
çevre eğitimi kavramını doğurmuştur. Çevrenin kendi başına bir özne olarak işaret edildiği ilk durumlardan birinin, ünlü filozof Jean-Jacques Rousseau (1712-1778)'nun çevreye odaklı bir eğitim anlayışı önerisi olduğu savunulabilir. Louis Agasiz (1807-1873) adlı eğitimcinin kitap odaklı öğrenmeyi değil de doğa gözlemi yoluyla öğrenmeyi önermesi dikkatleri bu alana çekmektedir. 1891 yılında Wilbur Jackman'ın yazdığı Nature Study for the Common School adlı kitap çevre eğitimi tanımının geçtiği ilk kitap olup, çevre eğitimi kavramının 1800'lerde oluşmaya başladığını göstermektedir. Filozof ve eğitim kuramcısı John Dewey (1859-1952) tarafından geliştirilen, bütünsel bakış açısına sahip ilerlemeci eğitim modeli yaparak-yaşayarak öğrenme, disiplinler arası öğretimi savunarak bugünkü çevre eğitimi yaklaşımının temellerini oluşturmuştur (McCrea, 2006).

Çevre eğitimi kavramının oluşmasındaki en büyük etkenin çevre sorunlarının 20. yüzyılda hız kazanması ve hayatı olumsuz yönde etkilemeye başlaması gösterilebilir. Mesela Amerika Birleşik Devletleri ve Kanada'da 1930'dan 1936'ya kadar süren bozkır ve çayır topraklarına ciddi derecede ekolojik ve tarımsal zarar veren, 2,5 milyon insanın Amerika'nın orta bölgelerinden kıyı bölgelerine göç etmesine sebep olan Dust Bowl (Dirty Thirties) çevre felaketi sonucunda 1935'te koruyucu eğitim faaliyetleri geliştirilmiştir. 1934 yılında o dönemin ABD Başkanı Franklin d. Roosevelt doğaya karşı gelmek yerine doğayla işbirliği üzerine kurulu bir plan uygulayacağını ifade etmiştir (Montanarella, 2015). 1935'te sürdürülebilir tarım teknikleri geliştirmeyi amaçlayan ve bu konuda çiftçilere eğitim düzenleyen The Soil Conservation Act (Toprak Koruma Hareketi) başlatılmıştır. Yine aynı sene ABD'de National Education Association of The United States okulları çevreyi korumaya yönelik eğitim etkinlikleri uygulamıştır. 1946'da Wisconsin Üniversitesi'nde çevre korumacı eğitim alanında lisans derecesi önerilmiş, 1948 y1lında Uluslararası Doğayı Koruma Birliği'nin Paris'te gerçekleştirdiği toplantı çevre eğitimi teriminin kullanıldığı ilk resmi ve uluslararası mecra olmuştur. 20. yüzyılın ilk yarısında kaydedilen bu verilere bakılırsa çevre sorunlarının insan kaynaklı olduğu ve çözüm aşamasında eğitimin yerinin önemi anlaşılmıştır. Faaliyetlerin çoğunluğunun ABD'de olması dikkate değerdir (McCrea, 2006).

1969'da ABD'de yayınlanan The National Environmental Policy Act'in amac1; insan ve yaşadığı çevre arasında bir uyum oluşturmak, çevre ve biyosferi korumak ve verilen zararları azaltmayı amaçlamak, insanların sağlığını ve refahını önemsemek, ekolojik sistemlerin ve doğal kaynakların önemini kavratmaktır (Miner et al., 2010). The National Policy Act (NEPA), ilk ulusal çevre yasası olma özelliği yanında ÇED (Çevresel Etki Değerlendirmesi) kavramının kamuoyuna sunulduğu ilk belgedir. NEPA, ÇED kavramının dünya çapında çevre politikalarında yer almasını sağlamıştır (Akgül, 2013).

İngiltere'de, ilk defa Koole Üniversitesi'nde 1965 'te düzenlenen bir konferansta karşımıza çıkan çevre eğitimi kavramı 1968 'de Paris'te düzenlenen UNESCO Biyosfer Konferansı'nda tartışmaya açılarak uluslararası mecrada kendine yer bulmaya başlamıştır (McCrea, 2006). 22 Nisan 1970'de 20 milyon insanın kutladığı 1. Dünya Günü’nün (The Earth Day) kirlilik ve çevre sorunlarına kamu farkındalığı oluşturan, modern çevre eğitiminin temellerinin atıldığı ilk büyük resmi organizasyon olduğu söylenebilir. Düzenlenen sempozyum ve konferanslarda farklı sosyoekonomik-kültürel gruplardan binlerce kişi konuşma yapmıştır. Çevre sorunlarının çözümünün toplumda oluşacak çevre bilinciyle aşılabileceğinin farkına varan Senatör Gaylord Nelson'ın organizatörlüğünde gerçekleşen bu büyük etkinlik ABD'den dünyaya yayılarak Dünya Günü adı altında günümüzde de çeşitli çevreyi koruma etkinlikleriyle, bilgilendirme çalışmalarıyla farkındalık oluşturmaya devam etmektedir (Rome, 2010). 1972 senesinde Stockholm'de Birleşmiş Milletler tarafindan düzenlenen Çevre Konferansı uluslararası düzeyde çevre konusunu kamuoyuna sunan ve üzerinde çalışmalar yapan ilk organizasyondur. Bu konferans temel alınarak 1975'te Birleşmiş Milletler Çevre Programı (UNEP) ve Uluslararası Çevre Eğitimi Programı (IEEP) geliştirilmiştir. Çevre eğitimi konusundaki eksikliği gidermek için kurulan IEEP, 1977 yılında yapılan Tiflis Çevre Eğitimi Konferansı'nın sorumlusu olmuş, 1992'de gerçekleştirilen Rio Konferansı'nda sürdürülebilir kalkınma alanında etkin rol oynamıştır (Ünal \& Dımışkı, 1999). 
Birleşmiş Milletler'in 1975’te Belgrad‘da düzenlediği Belgrad Charter adlı Çevre Sorunları Eğitimi Toplantısında bilgilendirme, bilinçlendirme ve davranış kazandırma kademeleriyle çevre eğitiminin amaçları belirlenmiştir (Kaya vd., 2010). Çevre eğitiminin küresel düzeyde ilk basamakları sayılan bu gelişmelerden sonra 1977 yılının Ekim ayında Gürcistan'ın Tiflis kentinde düzenlenen UNESCO Birinci Hükümetler Arası Çevre Eğitimi Konferansının önemi büyüktür. Konferansta çevre eğitiminin örgün ve yaygın eğitime nasıl uygulanabileceği ayrıntılı olarak tartışılmış ve öneriler sunulmuştur. Çevre eğitiminin temelinin atıldığı bu organizasyonda çevre eğitimcilerinin günümüzde de kullandığı prensip ve yöntemler belirlenmiştir. $\mathrm{Bu}$ bildirgede Belgrad Konferansı'nda belirlenen hedefler doğrultusunda belirlenen çevre eğitiminin amaçları arasında 'çevrenin korunması ve geliştirilmesi adına bireyin bilgi, değer, davranış, sorumluluk ve yeteneklere sahip olmalarını sağlamak' ve 'çevreye karşı toplum, grup ve bireylerin davranışlarının değişimini sağlamak' vardır (Gökmen vd., 2019). Bu amaçları elde edebilmek için oluşturulan beş eylem şunlardır:

-Çevreye yönelik hassasiyet ve sorumluluk bilinci kazanma (bilinçlenme düzeyi),

-İnsan kaynaklı çevre problemlerinden haberdar olma, bu konuya yönelik tecrübeler edinme (bilgi düzeyi),

-Sorumluluk alarak çevrenin korunması ve gelişmesi için faaliyetlerde bulunma (davranış düzeyi),

-Sorunların çözümü için gerekli yeterliliklerin sağlanması (yetenek düzeyi),

-Sorunlara yönelik bilgi sahibi olan bireylerin çözüm sürecine aktif katılımı (katılım düzeyi) (UNESCO-UNEP, 1978; Ünal \& Dımışkı, 1999)

Tiflis Bildirgesi'nde alınan kararlar çevre eğitimine yönelik yapılan konferansların ve alınan kararların temelin oluşturmuş, çevre eğitimi günümüzde sürdürülebilir kalkınmaya yönelik eğitime evrilmiş olsa da Tiflis Bildirgesi'nin belirlediği çerçeveden uzaklaşılmamıştır.

1980'de Dünya Doğa ve Doğal Kaynakları Koruma Birliği (IUCN), UNEP ve WWF'nin katkılarıla The World Conservation Strategy adlı belgeyi yayınlamıştır. Bu önemli belge dikkatleri çevreyi koruma anlayışından sürdürülebilir kalkınma anlayışına çekerken, aslında bu iki kavramın birbirine bağımlı olduğunu belirtmiştir. The World Conservation Strategy'de yer alan bir bölümde çevre eğitimine yönelik bir mesaj yer almaktadır: 'Eğer koruma hedeflerinin başarıya ulaşmasını istiyorsak bütün toplulukların biyosfere yönelik tutumları değişmelidir. Çevre eğitiminin uzun dönemli görevi bu yeni etik yaklaşıma uygun davranış ve yaklaşımları teşvik etmek ve pekiştirmektir' (Allen, 1980). Tiflis Bildirgesi'nden on sene sonra 1990'l1 y1llarda uygulanacak çevre eğitim politikası ve stratejilerini bu bildirgede alınan kararlar üzerine konumlandırmak için 1987 yılında UNESCO ve UNEP Moskova Çevre Eğitimi Konferansı adında Çevre Eğitimi ve Uygulamaları üzerine eğitici bir kongre düzenlemiştir (UNESCO-UNEP-IEPP, 1992; Ünal \& Dımışkı, 1999). Bu kongrede insan ihtiyaçlarının karşılanmasının sürekliliğinin sağlanması için çevreyi korumanın zorunlu olduğu tüm toplum tarafından anlaşılıp bilinç kazandırılmazsa çevreye yönelik bölgesel ve küresel tehditlerde uzun dönemde hiçbir azalma olmayacağı vurgulanmıştır. İnsan davranışlarının çoğunlukla toplumdaki yaygın inanışlara ve bakış açılarına dayandığı, bu yüzden herkesin gerekli düzeyde çevre eğitimi alıp, çevre hakkında bilinçlenmesinin önemli olduğuna dikkat çekilmiştir (UNESCO-UNEP-IEEP, 1992). Çevre eğitimi 1970'lerden itibaren bütünsel olarak kabul edilmiş Fen, Coğrafya, Matematik gibi alanlarla ilişkilendirilmiştir (Karrow \& Fazio, 2015; UNESCO, 1992).

1990'da İngiltere'de yayınlanan National Curriculum Documentation for Environmental Education (Çevre Eğitimi için Ulusal Müfredat Belgesi) adlı belgede çevre meselelerinin öğretilmesi zorunlu kılınmıştır. Mevcut müfredat, Ulusal Müfredat Kurulu'nun çevre eğitimi kılavuzunu yayınlamasıyla tamamlanmıştır (National Curriculum Council, 1990). Yine aynı sene 
1975 'te öğrencilerin çevreye yönelik bilgi ve farkındalıklarını artırmak amacıyla 'Project Learning Tree' adıyla ABD‘de gerçekleştirilen projede 200000 eğitmen tarafından 10 milyon öğrenci çevre eğitimi dersi almıştır (Güler, 2009). 1980'de UNESCO Çevre Eğitimi Programı tarafından Çevre Eğitimi Müfredat Geliştirme Stratejileri'nin yayınlanmasının ardından ABD'de müfredat üzerine çalışan akademisyenler tarafından The Journal of Environmental Education (Çevre Eğitimi Günlüğü) yayınlanmıştır (Hungerford et al., 1986). Bu gelişmeden 10 sene sonra 1990'da ABD Meclisinde Ulusal Çevre Eğitimi Hareketi kabul edilmiştir. Bu paketin içeriğinde Çevre Eğitimi Bürosu, Çevre Eğitimi Hibe Programı, Başkanlık Gençlik Çevre Ödülü, Çevre Eğitimi ve Çevre Öğretimi Fonu gibi bölümler vardır. 1992 yılında Birleşik Devletler Çevre Koruma Ajansı ve Michigan Üniversitesi işbirliğiyle Çevre Eğitimi ve Öğretimi Programı'nı geliştirmiş ve uygulamıştır (McCrea, 2006).

ABD‘deki gelişmelerden sonra Avrupa'daki gelişmeleri incelersek Avrupa Birliği'nin 1988'i European Year of the Environment (Avrupa Çevre Yılı) olarak kutladığı görülür. Bu belgede çevre problemlerine yönelik çözümler önerilmiş ve çevre eğitimi kapsamında kararlar alınmıştır (Karataş \& Aslan, 2012). Avrupa Konseyi’nin 2006 yılında yayınladığ 1 Council of The European Union'da sadece karar almanın yeterli olmadığı, toplumların kararları doğru algılamasının ve uygulanmasının daha önemli olduğu savunulmuştur. Bunun üzerine Brüksel sonuç raporunda eğitim sistemlerinin sürdürülebilir kalkınmayı desteklemesi için uyarlamalar yapılması gerektiğine dikkat çekilmiştir (Commission of the European Communities, 2001; Tanrıverdi, 2009). UNESCO'nun 2005'te Sürdürülebilirlik Açısından Öğretmen Eğitimin Yeniden Planlama Önerileri ve Rehberi’nde eğitimin aktif katılımla verilmesi gerektiği sürdürülebilirlik için gerekli değer ve tutumların kazandırılmasının önemli olduğu belirtilmiştir. Öğrenci merkezli eğitim etkinliklerinin uygulanmasının eğitimin başarısını arttıracağı vurgulanmıştır (Tanrıverdi, 2009; UNESCO, 2005a).

Avrupa Birliği çevre sorunlarının önlenmesi zorunluluğunu göz önünde bulundurarak çevre politikaları ve çevre eylem programları hazırlamış, bu politikalar sadece AB ülkelerini değil dünyanın tamamına örnek olmuştur (Aydın \& Çamur, 2017). Çevre eylem planlarında çevre eğitiminin zorunluluğu dile getirilmiştir (Aydın \& Çamur, 2017; Kılıç, 2001). AB ülkelerinde ve anlaşmalarında çevre eğitiminin sürdürülebilir kalkınma eğitimine dönüştürülmesi gerektiğinin vurgulandığı bir ortamda, bazı Avrupa ülkelerinde çevre eğitimi ayrı bir ders olarak verilmekte, bazı ülkelerde de çeşitli derslerin içeriğine eklenerek uygulanmaktadır (Stokes et al., 2001; Tanrıverdi, 2009).

BM Avrupa Ekonomik Konseyi (UNECE) Sürdürülebilir Kalkınma İçin Eğitim Stratejisi gereğince üye ülkeleri sürdürülebilir kalkınma eğitiminin geliştirmeye ve tüm eğitim süreçlerine dâhil etmeye yönlendirmektedir. Sürdürülebilir gelişme için tüm insanları doğayla uyumlu, üretken ve sosyal değerlere önem veren bireyler haline getirmek amaçlanmaktadır (Ünal \& Dımışkı, 1999).

Uluslararası düzeydeki gelişmelere döndüğümüzde 1987 yılında yayınlanan Brundtland Raporu sürdürülebilirlik kavramının uluslararası mecrada bilinirliğini sağlamış, kısa dönemli ekonomik başarılardan ziyade uzun vadeli ekonomilerin inşa edilmesi gerektiğine ve tüm toplumun sürece dâhil edilmesinin önemli olduğuna vurgu yaparak, çevre farkındalığı oluşturmada bir kilometre taş1 görevi yapmıştır (Han \& Kaya, 2012; Karabıçak \& Özdemir, 2015). 1992 yılında yapılan Rio Konferansı'nda yayınlanan 40 maddeden oluşan Gündem 21'in 36. Bölümünde, sürdürülebilir kalkınmayı destekleyen tutumları ve davranışları oluşturmak ve güçlendirmek için küresel bir eğitim çabasından bahsedilmektedir. Gündem 21'de devletler, uluslararası ajanslar, iş dünyası ve sivil toplum kuruluşlarının uymaları için çağrı yapılan amaçlar şunlardır:

-Tüm yaş gruplarına çevre ve kalkınma eğitiminin verilmesi,

-Çevre ve kalkınma eğitiminin tüm eğitim programlarına dâhil edilmesi, 
-İlköğretim düzeyindeki öğrencilerin doğal kaynak kullanımı, içme suyu kalitesi, çevre sağlı̆̆ gibi konulardaki çalışmalara katılımı (United Nations Conference on Environment and Development, 1992; Smyth, 1999).

Rio Konferansı'ndan 5 sene sonra 1997'de Birleşmiş Milletler Sürdürülebilir Kalkınma Komisyonu'nca Selanik'te düzenlenen Uluslararası Çevre ve Toplum Konferansı: Sürdürülebilirlik İçin Eğitim ve Toplum Bilinci adlı konferansta 1977 Tiflis Bildirgesi’nde alınan kararların geçerliliğini koruduğu, sürdürülebilir kalkınma eğitiminin bu kararlar doğrultusunda eğitim sistemine nasıl dâhil edilebileceği tartışılmıştır (Ünal \& Dımışkı, 1999).

Tablo 1: Çevre Eğitimi ve Sürdürülebilir Kalkınma İçin Eğitimin Karşılaştırılması (Pace, 2010; UNESCO-UNEP, 1978; UNESCO, 2005b).

\begin{tabular}{|c|c|}
\hline Çevre Eğitimi & Sürdürülebilir Kalkınma İçin Eğitim \\
\hline $\begin{array}{c}\text { Çevre Eğitimi Tiflis Konferansı'nda (1978) } \\
\text { önerilmiştir }\end{array}$ & $\begin{array}{c}\text { Sürdürülebilir Kalkınma İçin Eğitim, UN DESD } \\
\text { (Decade Education for Sustainable Development) } \\
\text { tarafından önerilmiştir (2005) }\end{array}$ \\
\hline $\begin{array}{l}\text { Çevreyi doğal, teknolojik ve sosyal boyutlarda ele } \\
\text { alarak bütünsel bir bakış açısı sunar. }\end{array}$ & $\begin{array}{l}\text { Sürdürülebilirliği destekleyen üç ana temel üzerine } \\
\text { inşa edilir: çevre, toplum ve ekonomi. }\end{array}$ \\
\hline $\begin{array}{l}\text { Her yaş için her düzeyde örgün ve yaygın eğitimi } \\
\text { kapsayarak ömür boyu devam edecek bir süreçtir. }\end{array}$ & $\begin{array}{l}\text { Yaşam boyu öğrenmeyi destekleyen örgün ve yaygın } \\
\text { eğitimle ilgilenir. }\end{array}$ \\
\hline $\begin{array}{c}\text { Çevre sorunlarının çözümü için yerel, ulusal, bölgesel } \\
\text { ve uluslararası işbirliğini teşvik eder. }\end{array}$ & $\begin{array}{c}\text { Yerel ihtiyaçların karşılanmasına önem vermekle } \\
\text { birlikte bu ihtiyaçların karşı1lanmasının küresel } \\
\text { etkileri olduğunu kabul eder. }\end{array}$ \\
\hline $\begin{array}{l}\text { Tarihsel perspektifi dikkate alırken mevcut ve } \\
\text { potansiyel çevre sorunlarıla ilgilenir. }\end{array}$ & Kültüre önem verir ve yerelle ilgilenir. \\
\hline $\begin{array}{l}\text { Kalkınma ve büyüme planlarında çevreyi ön plana } \\
\text { alır. Kaynakların kullanımının çevrede değişiklere } \\
\text { sebep olduğunu bilir. Öğrencinin çevre sorunlarının } \\
\text { nedenlerini ve sebep olduğu etkileri anlamasını } \\
\text { sağlar. }\end{array}$ & $\begin{array}{c}\text { Sürdürülebilirlik kavramının gerektirdiği koşullara } \\
\text { uyum sağlar. }\end{array}$ \\
\hline $\begin{array}{l}\text { Daha iyi bir yarın inşa etmek için girişimciliği, } \\
\text { sorumluluk duygusu ve bağlılığ teşvik eder. }\end{array}$ & $\begin{array}{c}\text { Uyarlanabilir iş gücü, yaşam kalitesi ve çevresel } \\
\text { yönetim için bireylerin gelişimiyle oluşan toplum } \\
\text { temelli karar verme yetisi geliştirir. }\end{array}$ \\
\hline $\begin{array}{c}\text { Bireyi eleştirel düşünmeye ve problem çözme } \\
\text { sürecine dâhil etmeyi planlar. }\end{array}$ & $\begin{array}{c}\text { Katılımcı öğrenmeyi ve yüksek düşünme becerilerini } \\
\text { geliştirmeye yönelik teknikler kullanır. }\end{array}$ \\
\hline
\end{tabular}

Çevre eğitiminden sürdürülebilir kalkınma eğitimine dönüştürülen eğitim anlayışı incelendiğinde 1970'lerde oluşturulmaya çalışılan doğal kaynakların ve çevrenin tahribatına yönelik farkındalık yaratmak ve koruyucu önlemlerin alınmasında rol almak olarak tanımlayabileceğimiz çevre eğitimi anlayışı, ekonomik gelişmenin yani mevcut üretimin devamlılı̆̆ını sağlama amacıyla doğal kaynakları korumaya yönelik bir bakış açısına dönüştürülmüsştür. Çevreyi korumak ana amaç iken, sürdürülebilir kalkınma için bir gereklilik olduğu için araca dönüştürülmüştür (Tablo 1).

UNESCO, Birleşmiş Milletler Sürdürülebilir Kalkınma İçin Eğitimin 10 Yılı adlı planı 2005-2014 yılları arasındaki 10 yıllık süreci sürdürülebilir kalkınma için eğitim yılları belirlemiştir. 2005 yılında ülkelerin kullanımına sunulan bu planda:

-Sürdürülebilir kalkınma eğitimi alanında tüm paydaşlara yönelik vizyon geliştirmek,

-Sivil toplum, eğitim kurumları, hükümetler arası, medya, özel sektör gibi paydaşların ortakl1klar kurmas1,

-İyi örnekleri desteklemek amacıyla yeni projelerin oluşturulması gibi etkinlikler düzenlenmiştir (UNESCO, 2009). 
1980’li yıllarda sürdürülebilir kalkınma anlayışının gelişmesi sürdürülebilir çevre eğitimi anlayışını doğurmuştur. UNESCO 1975 ile 1995 seneleri arasında uygulamaya koyduğu Uluslararası Çevre Eğitimi Programını Sürdürülebilir Gelecek İçin Eğitim Programıyla değiştirmiştir (Tanrıverdi, 2009; UNESCO, 1997). Sürdürülebilir kalkınmanın temelinin doğal kaynakları korumak olduğu paylaşımının adaletli olarak yapılmasının insanları bilinçlendirmekten geçtiği, bunun da sürdürülebilir çevre eğitimi ile mümkün olacağı vurgulanmıştır (Sauvé, 1996; Tanrıverdi, 2009). Böyle olmakla birlikte çevre eğitimi ve sürdürülebilirlik karş1lıklı etkileşim içerisinde olup, birbirini tamamlamakta ve içermektedir.

1997'de Selanik’te Uluslararası Çevre ve Toplum Konferansı: Sürdürülebilirlik İçin Eğitim ve Toplum Bilinci adıyla yapılan konferansta Tiflis Bildirgesi'nde kabul edilen maddelerin geçerliliğinin devam etmesi kararı alınmış, sürdürülebilir kalkınma için eğitim yöntemleri belirlenmiştir (Ünal \& Dımışk1, 1999). 2002 yılında Güney Afrika'da yapılan ve 189 ülkeden katılımcının bulunduğu Johannesburg Zirvesi'nde toplumun her bölümünden insan zirvenin her aşamasına dâhil edilmeye çalışılmıştır. Bunun sebebi sürdürülebilir kalkınmanın sağlanması için çevre farkındalığının ve hassasiyetinin gerektirdiği davranışların tüm toplum tarafından benimsenmesi gereğidir. 2012'de yapılan Rio+20 BM Sürdürülebilir Kalkınma Konferansı'nda Johannesburg Zirvesi'nde olduğu gibi toplumun tüm kademelerinin sürdürülebilir kalkınma sürecine dâhil edilmesi gerekliliği vurgulanmıştır (Türk \& Erciş, 2017).

2002 yılında yayınlanan Maastricht Küresel Eğitim Bildirgesi’nde küreselleşmenin getirdiği yeni olasılıklar, eşitlik ve insan hakları gibi konular hakkında bilinçlendirmeye yönelik küresel eğitim kavramı ortaya atılmıştır. Küresel eğitim, kalkınma eğitimi ve sürdürülebilirlik eğitimi boyutlarını da kapsayan bir eğitim anlayışıdır. Birleşmiş Milletler Sürdürülebilir Kalkınma İçin Eğitimin On Yılı raporunda sürdürülebilir bir hayat hedefiyle herkesin bilgi sahibi olma, çeşitli hayat tarzlarından haberdar olma ve bu konuda inisiyatif alma hakkı olduğuna değinilmiştir. 2007 yılında yapılan Avrupa Kalkınma Mutabakatı: Kalkınma Eğitimi ve Farkındalığının Artması adlı toplantıda sürdürülebilir kalkınmayı olumsuz etkileyen yerel ve küresel değişkenler üzerinde her yaştan insanın bireysel etkilerinin farkında olması, çevre hakkının doğurduğu sorumluluğun gereklerini yerine getirecek bir toplumun önemi üzerinde durulmuştur. $\mathrm{Bu}$ süreçler sonucunda sürdürülebilirliğin, eşitliğin ve kalkınmanın yaygınlaştırılması uluslararası bir ortak mutabakata varılmasıyla ve bu yönde atılan adımların etkinleştirilmesiyle mümkündür. Bunun yolu da örgün ve yaygın eğitimle, çeşitli eğitim organizasyonlanıla hatta medya yoluyla insanları bilinçlendirmekten geçmektedir (Carvalho da Silva, 2008).

2010 yılında Dünya Meteoroloji Organizasyonu (WMO) ile Birleşmiş Milletler Çevre Programı'nın (UNEP) yayınladığı raporda ozon tabakasındaki tahribatın azalmaya başladığı, insanların bilinçlenmesinin çevre sorunlarının çözümünde büyük rol oynadığının bu olumlu gelişmeyle anlaşıldığı vurgulanmıştır (Çabuk, 2019; United Nations Environment Programme Agency \& World Meteorological Organization, 2010).

1977'de çevre eğitiminin genel hedefleri ve yöntemlerinin belirlendiği Tiflis Konferansı'ndan on sene sonra gidişatı değerlendirmek, kurumsal stratejileri belirlemek, çevre eğitimini güçlendirmek için Moskova Uluslararası Çevre Eğitimi ve Yetiştirme Konferans1 düzenlenmiştir. Tiflis Bildirgesi'nin 20. senesinde düzenlenen Selanik Konferans1 çevre eğitiminin sürdürülebilir kalkınma içindeki yerini belirlemek amacıyla düzenlenmiştir. 30. yılda düzenlenen Ahmedabad Çevre Eğitimi Konferansı'nda çevre sorunlarının kirlilik ve nüfus artışından küresel iklim değişikliğine doğru bir geçiş yaptığı, sorunların sağlık, yoksulluk, eğitim hakkı, kirlilik, üretim ve tüketim, su kaynaklarının yok olması gibi birbiriyle bağlantılı daha geniş bir yapıya dönüştüğü, eğitim sürecinin daha kapsamlı ve bütünsel olması gerektiği sonucuna ulaşılmıştır (UNEVOC, 2007).

2015’te Birleşmiş Milletler Genel Kurulu'nda, Sürdürülebilir Kalkınma 2030 Hedefleri belirlenmiştir. 17 ana hedef üzerinde uzlaşılan bu kurulda nitelikli eğitim hedefleri arasında 2030 
y1lına kadar sürdürülebilir kalkınmayı ve sürdürülebilir yaşam tarzlarının desteklenmesi için eğitim faaliyetlerinin etkinleştirilmesi de vardır (UNESCO Türkiye Milli Komisyonu, 2018).

1900'lerin başında kavramsallaşmaya başlayan çevre sorunlarının tek kaynağının insan faaliyetleri olması, zaman ilerledikçe bu konuyu tartışmak ve çözüm önerileri sunmak için yerel, ulusal ve uluslararası düzeylerde etkinliklerin yapılmasına, kararların alınmasına sebep olmuştur. Alınan kararlara küresel düzeyde katılımının sağlanması çevre sorunlarının çözümü için hayati önem taşımakta, katılımın sağlanması da farkındalık kazandırma ve çevre bilinci oluşturmayla mümkün olmaktadır. Bu durum çevreyi korumaya yönelik eğitim anlayışını ortaya çıkarmış, çevre eğitimi ile ilgili ilk uluslararası konferansın 1977'de Tiflis'te gerçekleştirilmesinden sonra 1980'lerde oluşan sürdürülebilir kalkınma anlayışının etkisiyle çevre sorunlarını önlemeye yönelik çevre eğitimi anlayışından sürdürülebilir ekonomiler için çevre eğitimi anlayışına geçiş yapılmıştır. Tiflis Konferansı'nın 30. senesinde yapılan Selanik Konferansı'nda bu geçişin nasıl olacağı tartışılmış, 40. yılda düzenlenen Ahmedabad Konferansı'nda iklim değişikliğinin ciddi olumsuz etkilerinin bertarafi için daha kapsamlı ve bütünsel eğitim uygulamalarının şart olduğu belirtilmiştir. İnsan yaşamını küresel boyutta tehdit etme noktasına gelen çevre felaketlerinin önüne geçilmesi için çevre eğitiminin etkin ve yaygın olarak uygulanması her geçen gün daha iyi anlaşılmaktadır.

\section{Türkiye'de Beş Yıllık Kalkınma Planlarında ve Diğer Resmi Belgelerde Çevre Eğitimi}

Roma Kulübü tarafından yayınlanan 'Büyümenin Sınırları' başlıklı raporda bireysel çevre farkındalığı ve bu bilincin gerektirdiği olumlu davranış değişikliklerinin ülkelerin sürdürülebilir kalkınmayı destekleyen politikalarından daha önemli ve etkili olduğu savunulmuştur (Özsoy, 2011; Türk \& Erciş, 2017). Türkiye'nin sürdürülebilir kalkınma politikalarını etkili bir biçimde uygulayabilmesi için bireysel ve toplumsal bilinç oluşturulmalı ve politikaların seyri toplumun desteğiyle güçlendirilmelidir (Türk \& Erciş, 2017). Beş yıllık kalkınma planlarında çevre eğitimine dair gelişmeleri incelersek: 1963-1967 yıllarını kapsayan 1. Beş Yıllık Kalkınma Planı ve 19681972 yıllarını kapsayan 2. Beş Yıllık Kalkınma Planı'nda çevre eğitimine dair bir bulguya rastlanmamaktadır. Bunun sebebi olarak söz konusu dönemin dünya çapında ve Türkiye'de çevre bilinci ve çevreyi koruma sorumluluğunun çok düşük seviyede olması gösterilebilir. Çevre eğitimi kavramına ilk defa 1973-1977 yılları arasını kapsayan 3. Beş Yıllık Kalkınma Planı'nda yer verilmiştir. Çevre sorunlarının en büyük sebebinin halkın eğitim yetersizliği olduğu; çevrenin korunması için halkın eğitilmesi gerektiğinden bahsedilerek çevre eğitimi kavramı Beş Yıllık Kalkınma Planları'nda yer almaya başlamıștır. Bu durumun sebebi, 1972'de yapılan Stockholm Çevre Konferansı'nın uluslararası düzeyde oluşturduğu bilinçlenmenin Türkiye'deki yansıması olarak gösterilebilir (Yurdakul Erol, 2012). 4. Beş Yıllık Kalkınma Planı'nda (T.C. Başbakanlık Devlet Planlama Teşkilatı Müsteşarlığı, 1979) çevre sorunlarının toplum dâhil edilmeden çözülemeyeceği, eğitimin bu konuda önemli olduğu belirtilmiştir. Ayrıca eğitim konusunda kurumlar arası işbirliğinin yetersiz olduğu, gerekli girişimlerin yapılmasının şart olduğu eklenmiştir. 5. Beş Yıllık Kalkınma Planı'nda (DPT, 1984) erozyon, şehirleşme, doğal afetler, hızlı sanayileşme ve tarımda modernleşme olarak sıralanan çevre sorunlarından bahsedilmiş, çevrenin gelecek nesiller için korunması gerektiğinden hareketle araştırma ve geliştirme faaliyetlerini artırmaya yönelik planlar yapılmıştır. Bu BYKP'de çevre eğitimine yönelik bir ibare bulunmamaktadır. 6. Beş Yıllık Kalkınma Planı'nda orman ve doğa sevgisini topluma kazandırmak için her türlü özelliğiyle (sosyal, tarihsel, ekolojik, bilimsel) ormanlık alanları tanıtmak için Uludağ, Yedigöller ve bu özellikteki yerlerde 'tabiat okulu' kurulması ve bu kurumların içindeki danışma merkezlerinin tanıtıcı hizmet vermeleri planlanmıștır. Bu BYKP'de bütün planlama süreçlerinde çevre boyutunun göz ardı edilmeyeceği ve çevre bilincini artırıcı uygulamaların yapılacağı belirtilmektedir. Çevre sorunlarını önleyici olarak çevre farkındalığı ve çevre hassasiyetinin toplumda kabul gören değerler arasına katılacağı ifade edilmektedir (T.C. Başbakanlık Devlet Planlama Teşkilatı Müsteşarlığı, 1989). 1996-2000 yıllarını kapsayan 7. Beş 
Yıllık Kalkınma Planı'nda ise çevre yönetiminin halkın katılımıyla yürütülmesi gerektiği, gönüllü kuruluşların yerel düzeyde kalan etkilerinin tüm katmanlara ve sürece yayılması için örgün eğitim sistemi içine konulan çevre eğitim derslerinin yeterli olmadığı, çevre eğitiminin tüm topluma verilmesi gerektiği belirtilmektedir. Bunun yanında çevre eğitimi alanında uzmanlaşma için eğitim programlarının oluşturulmasının şart olduğu ifade edilmiştir. Ayrıca sürdürülebilir kalkınma hedefinin gerçekleştirilebilmesi için gerekli olan çevre bilincinin yaygınlaştırılması için örgün ve yaygın eğitim programlarında düzenlemeler yapılacağının vurgulanması dikkate değer bir noktadır (T.C. Başbakanlık Devlet Planlama Teşkilatı Müsteşarlığı, 1995). 2001-2005 yılları arasını kapsayan 8. Beş Yıllık Kalkınma Planı'nda çevre yönetimi kapasitesinin ve yönetim araçlarının etkinliğinin artırılacağı belirtilmiştir. Çevre koruma hassasiyetine yönelik ifadelerin bulunduğu bu BYKP'de çevre eğitimine dair bir bölüm bulunmamaktadır (T.C. Başbakanlık Devlet Planlama Teşkilatı Müsteşarllğı, 2000). Bu planda sürdürülebilir orman yönetimi için gerekli olan ekosistem ağırlıklı eğitim noksanlığından bahsedilmiştir. 2007-2013 yıllarını kapsayan 9. BYKP'de BM İklim Değişikliği Çerçeve Sözleşmesi'nin gerektirdiği sera gazı emisyonunu azaltmak amaciyla bir Ulusal Eylem Planı'nın hazırlanmasına karar verilmiştir. Bu BYKP'de çevre bilincinin artırılmasına yönelik eğitim faaliyetlerinin ve kamuoyu çalışmalarının yapılacağı belirtilmiştir (T.C. Başbakanlık Devlet Planlama Teşkilatı Müsteşarlığı, 2006). Ekonomik gelişme kesintiye uğratılmadan çevre bilincinin artırılması, doğal kaynakların bugünün ve gelecek nesillerin ihtiyacını karşılamaya yetebilecek düzeyde ve kalitede olması koşulları 2014-2018 yıllarını kapsayan 10. BYKP'de yer almaktadır (T.C. Kalkınma Bakanlı̆̆ı, 2013). 2019-2023 yıllarını kapsayan 11. BYKP'de sürekli artan nüfus, şehirleşme, ekonomik faaliyetler, talebin ve tüketimin sürekli çeşitlenmesi ve artması sürdürülebilir çevre ve doğal kaynak yönetimi ile yaşanabilir kentler oluşturulmasını gerekli kılacağı, bunun da ancak tüm paydaşların katılımıyla mümkün olabileceği belirtilmektedir. Çevre kirliliğinin önlenmesine, biyolojik çeşitliliğinin ve doğada bulunan kaynakların korunmasına ve sürdürülebilir kullanımına öncelik verilmesi gerektiğinin altını çizen son BYKP'de çevre eğitimine yönelik ayrıca bir ifadeye yer verilmemiştir (T. C. Cumhurbaşkanlığı Strateji ve Bütçe Başkanlığı, 2019).

Beş Y1llk Kalkınma Planları'ndan sonra bakanlık belgelerinde ve yasalardaki çevre eğitimiyle ilgili bulgulara geçecek olursak; Türkiye'de çevreye yönelik ilginin belirgin bir şekilde 1970’lerde başladığı gözlemlenirken çevreye ilişkin yasal düzenleme olarak çevre hakkının 1982 yılında anayasaya dâhil edilmesi, Çevre Mevzuatı'nı iki döneme ayırmıştır. 1982'ye kadar çevreyi korumayı dolaylı olarak amaç edinen düzenlemeler yapılmışken, 1982‘den itibaren doğrudan çevre konularına yönelik düzenlemeler yapılagelmiştir. 1983 yılında yürürlüğe giren Çevre Kanununun 9. maddesinde çevrenin korunması ve toplumda farkındalığın artırılması amacıyla Milli Eğitim Bakanlığı'nın örgün eğitim kurumlarının her kademesinde çevreyle alakalı konuları bünyesinde barındırması gerektiği belirtilmiştir. 4 Temmuz 2011 tarihinde 'Çevre ve Şehircilik Bakanlığının Teşkilat ve Görevleri Hakkında Kanun Hükmünde Kararname’nin 2. maddesinde çevreyi korumak ve tahribatın etkilerini gidermek için gerekli eğitim planları oluşturmak ve uygulanmasını sağlamak görev olarak belirlenmiştir. Çevre ve Şehircilik Bakanlığı Yüksek Çevre Kurulu'nun Çalışma Usul ve Esaslarına İlişkin Yönetmeliğinin 5. maddesinde ulusal boyutta çevre eğitimi ile ilgili somut kararların var olmasına dair bir bölüm bulunmaktadır. Yine Çevre ve Şehircilik Bakanlığı Mahalli Çevre Kurulları Usul ve Esasları Yönetmeliğinin 5. maddesinde açık hava çevre etkinlikleri düzenlemeye yönelik bir görev bulunmaktadır (Ertürk, 2018). Çevre Kanunun 9. maddesinde radyo ve televizyon kanallarında çevre eğitimine yönelik programların yayınlanmasına zorunluluk getirilmektedir (Terzi, 2017). Türkiye'nin 'AB Entegre Çevre Uyum Stratejisi (UÇEŞ) 2007-2022', 2006 yılında Çevre ve Orman Bakanlığı tarafından hazırlanmıştır. UÇES' in AB Çevre Müktesebatı ile uyumlanması için barındırdığı ilkeler arasında toplumda çevre farkındalığının artması ve toplumun çevre yönetimine dâhil olması vardır. Çevre bilincinin sağlamlaştırılması için basınyayın organlarıyla bilgilendirme faaliyetleri ve eğitim çalışmaları yapılması alt amaçlar arasındadır (Ertürk, 2018). 
UNESCO'nun çevre eğitimi programını 1975'te yayınlamasına rağmen Türkiye'de çevre eğitimi bağımsız bir ders içeriği olarak okutulması, 1992 ile 1997 seneleri arasında ilkokullarda okutulan 'Çevre, Sağlık, Trafik ve Okuma' dersiyle, ortaokullarda seçmeli ders olarak 'Çevre ve İnsan' dersiyle başlamıştır (Çabuk, 2019; Ünal \& Dımışkı, 1999). 1999'da Milli Eğitim Bakanlığı ve Çevre Bakanlığı arasında imzalanan 'Çevre Eğitimi Konularında Yapılacak Çalışmalara İlişkin İşbirliği Protokolü'nde çevre eğitiminin örgün eğitimin ilk kademesinden itibaren sistemli ve uygulamalı olacak şekilde planlanmasının çevre farkındalığı ve çevre bilinci için önemi vurgulanmış, bu yönde karar alınmıştır (Kesicioğlu \& Alisinanoğlu, 2008; Çabuk, 2019). Çevre Eğitimi, Çevre ve İnsan, Türkiye'nin Çevre Sorunları, Çevre Felsefesi, Erken Çocukluk Dönemi Çevre Eğitimi ve Çevre Hukuku... yükseköğrenim programlarındaki çevre eğitimine yönelik dersler olarak karşımıza çıkmaktadır (Çabuk, 2019; Türkiye Cumhuriyeti Yüksek Öğretim Kurumu, 2018).

Tablo 2: Bazı Ülkelerin Çevre Eğitimine Etki Eden Faktörlerin Karşılaştırılması.

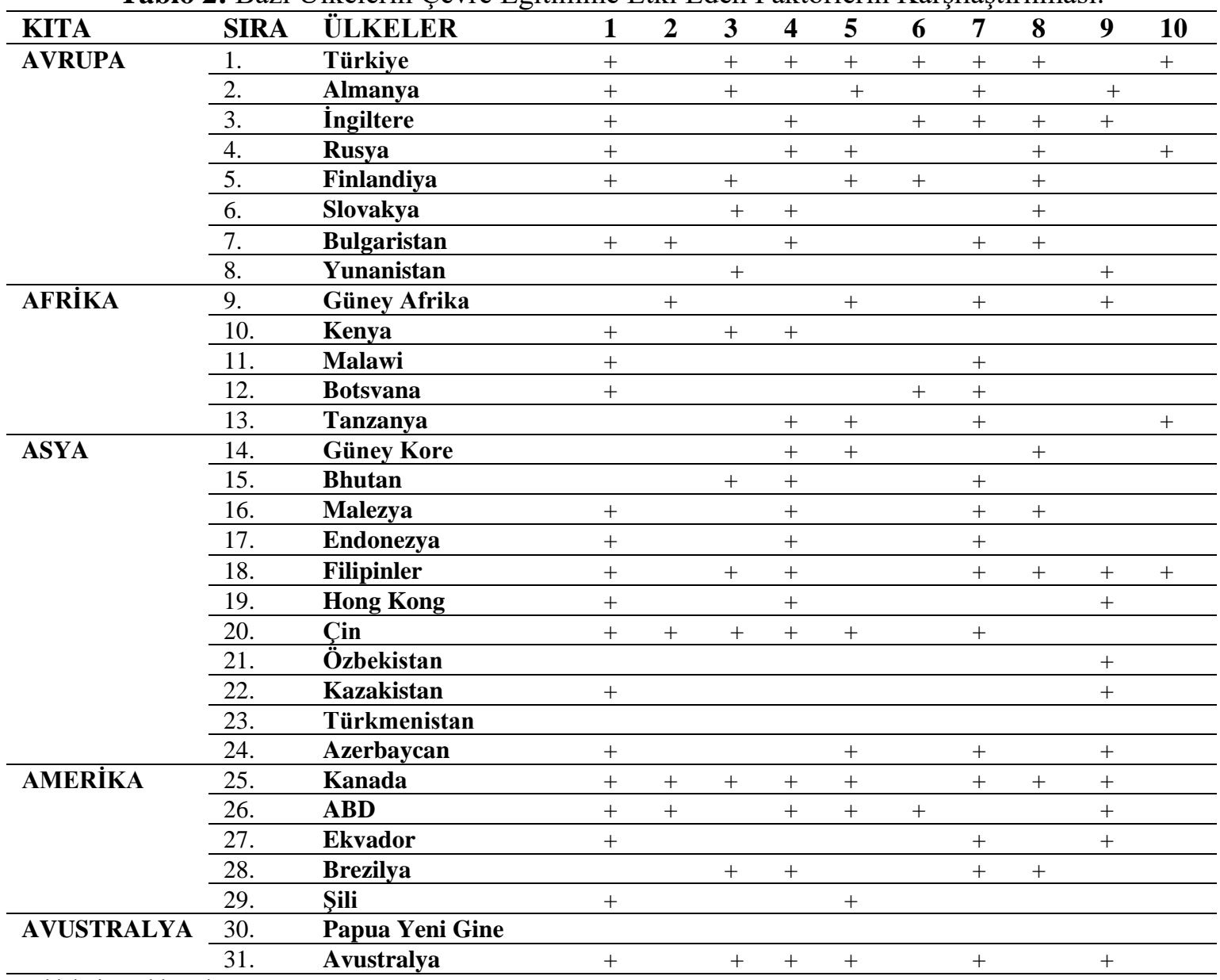

Maddelerin açıklamaları:

1. Çevre eğitimi örgün eğitimin yanında yaygın eğitimle de desteklenir (STK, Çevre Dernekleri, medya vb.).

2. 1970'lerden önce de çevre bilincine yönelik çevre politikaları mevcuttur.

3. Eko-okul uygulaması mevcuttur.

4. Çevre eğitimi, sürdürülebilir kalkınma eğitimi olarak tanımlanmaktadır.

5. Çevre eğitimi politikası gelişimi uluslararası gelişmelerle paralellik göstermektedir.

6. Sınıf dışı eğitim (açık hava) çevre etkinlikleri düzenlenmektedir.

7. Özel çevre eğitim politikası kurgulanmıştır.

8. Çevre eğitimine yönelik dersler müfredatlarda zorunludur.

9. Hükümet çevre ve çevre eğitimi konusunda duyarlıdır.

10. Çevre eğitimi çok disiplinli (bütünsel) uygulamaların yanı sıra ayrı bir ders (disiplinler arası) olarak verilmektedir. 
1534 Ali Ekber Gülersoy - Hilal Yener - Tuğçe Turgut - Dilay Melis Özşahin - Deniz Anter...

\section{Tablo 3: Bazı Ülkelerin Ön Plana Çıkan Çevre Eğitimi Politikaları Özellikleri. \\ KITA ÜLKELER ÜLKENİN ÖN PLANA ÇIKAN ÇEVRE EĞİTIMI POLITIKIKALARI ÖZELLIKLERI}

\begin{tabular}{|c|c|c|}
\hline \multirow[t]{8}{*}{ AVRUPA } & Türkiye & $\begin{array}{l}\text { Çevreye duyarlı yaklaşımların arttırılması, çevre dostu yeni teknolojilerin } \\
\text { desteklenmesi, yeşil liman uygulamalarının desteklenmesi, toplumu } \\
\text { bilinçlendirici faaliyetler yapılması öne çıan özelliklerinden bazılarıdır. } \\
\text { Bunlara ek olarak oteller, eko-okul uygulamaları ve Yeşil Kutu Projesi gibi } \\
\text { uygulamalara da yer verilebilir. }\end{array}$ \\
\hline & Almanya & $\begin{array}{l}\text { Her yıl } 16 \text { eyaletin temsil edildiği The Round Table (Yuvarlak Masa) adlı } \\
\text { toplantıda ESD (Sürdürülebilir Kalkınma Eğitimi)'ye yönelik kararlar } \\
\text { alınmaktadır. }\end{array}$ \\
\hline & İngiltere & $\begin{array}{l}\text { Öğretmenlere çevre hakkında mesleki eğitim sunulmuş, açık alan eğitimi } \\
\text { teşvik edilmiştir. }\end{array}$ \\
\hline & Rusya & $\begin{array}{l}\text { Çevre eğitimi, doğa koruma örgütleri ve okulların sosyal etkileşimi ile } \\
\text { uygulanmakta, bilgilendirme, teşvik edici destek, eğitim sürecinin } \\
\text { sürekliliği gibi ilkelere dayanmaktadır. }\end{array}$ \\
\hline & Finlandiya & 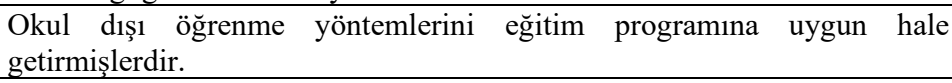 \\
\hline & Slovakya & $\begin{array}{l}\text { Eğitim Bakanlığı'nın direktiflerini uygulama aşamasında okullara özerklik } \\
\text { verilmiștir. }\end{array}$ \\
\hline & Bulgaristan & $\begin{array}{l}\text { Bulgaristan'da çevre eğitiminin gelişimi } 1972 \text { yılında başlamış ve devam } \\
\text { eden süreçte } 1992 \text { yılı sonrasında üniversitelerde çevre eğitimi ile alakalı } \\
\text { çalışmalar yapılmış, birçok eğitim kademesinde sürdürülebilir kalkınma } \\
\text { eğitimi verilmeye başlanmıştır. }\end{array}$ \\
\hline & Yunanistan & $\begin{array}{l}\text { Hükümet çevre ve çevre eğitimi konusunda duyarlı olup bu konu hakkında } \\
\text { destek sağlamaktadır. }\end{array}$ \\
\hline \multirow[t]{5}{*}{ AFRÍKA } & Güney Afrika & $\begin{array}{l}\text { Küresel çevre eğitimi politikası ile çevrenin her seviyede kalkınma } \\
\text { planlanmasının bütünleşmesi teşvik edilmiştir. }\end{array}$ \\
\hline & Kenya & $\begin{array}{l}\text { 1960'lardan bu yana Kenya Yaban Hayatı Kulüpleri aktif görev } \\
\text { yapmaktadır. }\end{array}$ \\
\hline & Malawi & $\begin{array}{l}\text { Sivil toplum kuruluşları ve gazete, dergi, televizyon, radyo gibi yayın } \\
\text { organları çeşitli yayınlar ile birlikte çevre programları hazırlayarak çevre } \\
\text { bilincinin oluşumunu sağlamada etkilidir. }\end{array}$ \\
\hline & Botsvana & $\begin{array}{l}\text { Örgün eğitimde zaman kısıtlılığ sebebiyle yeterli uygulanma imkân1 } \\
\text { bulunmayan çevre eğitimi, okul kulüplerinin açı hava çevre } \\
\text { etkinlikleriyle desteklenmektedir. }\end{array}$ \\
\hline & Tanzanya & $\begin{array}{l}\text { Uluslararası gelişmelerin etkilediği ülkede sürdürülebilir kalkınmaya } \\
\text { hizmet eden bireylerin yetişmesine yönelik bir çevre eğitimi bakış açısı } \\
\text { geliştirilmiştir. }\end{array}$ \\
\hline \multirow[t]{9}{*}{ ASYA } & Güney Kore & $\begin{array}{l}\text { Kullanılan çevre eğitimi politikası, çevrenin her seviyede kalkınma } \\
\text { planlanmasının bütünleşmesini teşvik etmektedir. }\end{array}$ \\
\hline & Bhutan & $\begin{array}{l}\text { Çevre eğitimi için kurulan Green School (Yeşil Okullar) ekolojik olarak } \\
\text { sürdürülebilir bir toplumun küçük bir örneği olarak görülür. }\end{array}$ \\
\hline & Malezya & $\begin{array}{l}\text { Green Growth adlı sürdürülebilir kalkınma politikasını desteklemek için } \\
\text { tasarlanan Sürdürülebilir Tüketim ve Üretim Eğitimi (ESCP) 'daha çok } \\
\text { kaynak ve daha az atık' sloganını benimsemiştir. }\end{array}$ \\
\hline & Endonezya & $\begin{array}{l}\text { Çevre eğitimi uygulamasında sadece eğitim kurumları değil gazeteciler, } \\
\text { çevreciler, yazarlar, TV ve radyo yapımcıları sorumlu tutulmuştur. }\end{array}$ \\
\hline & Filipinler & $\begin{array}{l}2040 \text { yılına kadar uygulanacak çevre eğitimi politikasını kurgulayan } \\
\text { ülkede çevre eğitimi örgün ve yaygın eğitim kurumlarında, kamu ve özel } \\
\text { sektörde uygulanmaktadır. }\end{array}$ \\
\hline & Hong Kong & $\begin{array}{l}\text { Uluslararası alanda etkili olan büyük şirketlerin (HSBC gibi) hizmet içi } \\
\text { çevre eğitimi uygulamaları vardır. }\end{array}$ \\
\hline & Çin & $\begin{array}{l}\text { Çin'de hem yetişkinler için hem de okullardaki öğrenimin her } \\
\text { kademesinde çevre eğitimi uygulamaları görülmektedir. }\end{array}$ \\
\hline & Özbekistan & Özbekistan'da halk kitleleri çevre politikalarının katılımcısıdır. \\
\hline & Kazakistan & $\begin{array}{l}\text { Kazakistan'ın çevre eğitimindeki hedefleri üç önemli aşamadan } \\
\text { oluşmaktadır; çevre kirliliğinin azaltılması, doğal kaynakların etkin } \\
\text { kullanılması, yenilenebilir enerji kaynaklarından pozitif yönlü } \\
\text { faydalanılmasıdır. Kazakistan'da çevre eğitimi alanında sivil gruplarca } \\
\text { faaliyetler düzenlenmekte, devlet bu etkinlikleri desteklemektedir. }\end{array}$ \\
\hline
\end{tabular}




\begin{tabular}{|c|c|c|}
\hline & Türkmenistan & $\begin{array}{l}\text { Türkmenistan'da tüm ülkeyi içerisine katan bir çevre koruma projesi } \\
\text { geliştirilmiştir. }\end{array}$ \\
\hline & Azerbaycan & $\begin{array}{l}\text { Çevre konusunda toplumun bilinçlendirilmesi amacıyla eğitim programları } \\
\text { hazırlanmaktadır. }\end{array}$ \\
\hline \multirow[t]{5}{*}{ AMERÍKA } & Kanada & $\begin{array}{l}\text { Başta bireysel girişimlerle başlayan çevre eğitimi, sonradan uluslararası } \\
\text { konferanslardan etkilenilerek hükümet politikalarında yer almış ve eğitim } \\
\text { kurumlarında okutulmaya başlamıştır. }\end{array}$ \\
\hline & ABD & $\begin{array}{l}\text { Günümüzdeki adıyla sürdürülebilirlik için çevre eğitimi ABD'de özellikle } \\
\text { EPA (Amerika Birleşik Devletleri Çevre Koruma Ajansı) aracılığı ile ciddi } \\
\text { bir ivme kazanmıştır. Eğitimin her seviyesinde çevre eğitimi } \\
\text { bulunmaktadır. }\end{array}$ \\
\hline & Ekvador & $\begin{array}{l}\text { Ekvador, çoğu ülkeden farklı olarak çevre eğitimi programlarını STK'lar } \\
\text { aracıllğı ile yürütmektedir. }\end{array}$ \\
\hline & Brezilya & $\begin{array}{l}\text { Brezilya'da çevre eğitimi politikaları 1980'li yıllarda başlamıştır. Eğitim } \\
\text { Bakanlığ1 sorumluluğunda hazırlanan program ile eğitimin her kademesine } \\
\text { çevre eğitimi konuları dâhil edilmiştir. }\end{array}$ \\
\hline & Şili & $\begin{array}{l}\text { Kitle iletişim araçları halkın çevre konusunda bilinçlenmesinde birincil } \\
\text { derecede etkilidir. }\end{array}$ \\
\hline \multirow[t]{2}{*}{ AVUSTRALYA } & Papua Yeni Gine & $\begin{array}{l}\text { Çevre koruma uygulamalarını anlatmak için ilkokulları ziyaret eden bir } \\
\text { eğitim ekibi vardır. }\end{array}$ \\
\hline & Avustralya & $\begin{array}{l}\text { Hükümet çevre ile ilgili güncel reformları takip etmekte ve eğitimcileri } \\
\text { desteklemektedir. Toplumu bilinçlendirme önemlidir. }\end{array}$ \\
\hline
\end{tabular}

\section{Sonuç, Tartışma ve Öneriler}

$\mathrm{Bu}$ bölümde araştırmanın sonuçları genel hatlarıyla belirtilecek ve bu çerçevede ideal bir çevre eğitim politikası için önerilerde bulunulacaktır.

\section{Sonuç ve Tartışma}

Genel olarak ülkemizdeki ve dünyadaki çevre politikalarının gelişim safhaları incelendiğinde bu politikaların başlangıcının 1970'li yıllar olduğu görülmektedir. Bunun en büyük sebebi artan çevre sorunları ve yaşanan çevresel felaketlerdir. İkinci Dünya Savaşı sonrası artan çevre sorunları geniş halk kitleleri için çok büyük problemler yaratmıştır. Bu problemlerin ışığında başta uluslararası kuruluşlar olmak üzere birçok resmi-özel kurum ve kuruluş, çevre koruma politikalarını geliştirmeye yönelmişlerdir. Bu yönelimlerin sonucunda gerçekleştirilen anlaşmalarla çevre politikasının temel ilkeleri belirlenmiş ve çoğu ülke söz konusu ilkeleri benimseyip bunların ışı̆̆ında çevre politikalarını tayin etmişlerdir.

1972 yılında düzenlenen BM İnsan Çevresi Konferansı (Stockholm Konferansı=UNCHE), ülkelerin çevre sorunlarına karşı politika üretmelerinin başlangıcı olarak kabul edilmektedir (Sarıçoban \& Yıldırımcı, 2015). Sonrasında 1992 yılında Rio de Janeiro'da düzenlenen "Çevre ve Kalkınma Konferansı" ülkelerin çevre konusundaki duyarlı olmalarını işaret eden ilkelerin kabul edilmesi açısından büyük bir önem arz etmektedir. 2002 yılında Johannesburg'da düzenlenen "Dünya Sürdürülebilir Kalkınma Zirvesi” (Torunoğlu, 2018) gibi etkinliklerle çevre koruma konusunda uluslararası anlamda önemli adımlar atılmıştır.

20. yüzyılın ilk yarısında yaşanan çevre felaketlerini, çevre eğitiminin gelişiminin en başat sebebi olarak gösterebiliriz. Çevre derneklerinin kurulması (NAAEE gibi), üniversitelerde çevre eğitimi ile ilgili konferanslar düzenlenmesi, NEPA adlı ilk ulusal çevre yasasının ABD'de yayınlanması gibi gelişmeler çevre sorunlarının uluslararası mecraya taşındığ 1970 'li yıllardan önce ortaya çıkmışlardır (Mccrea, 2006). 1970'de ABD'de düzenlenen ve 20 milyon insanın katıldığı, günümüzde tüm dünyada kutlanan Dünya Günü (The Earth Day)'nden sonra (Rome, 2010) 1972'de çevre konusunda düzenlenen ilk uluslararası konferans olan Stockholm Konferans1, büyük çaplı çalışmaların başlangıcı olmuştur. 1975 yılında Birleşmiş Milletler bünyesinde kurulan UNEP (Birleşmiş Milletler Çevre Programı) ve IEEP (Uluslararası Çevre Eğitimi Programı) ile çevre eğitimi politikaları oluşmaya başlamış, 1977 yılında Tiflis'te düzenlenen Çevre Eğitimi 
Konferansı ise çevre eğitimini konu alan ilk uluslararası konferanstır (Ünal \& Dımışkı, 1999). Konferansta belirlenen çerçeve, sonrasında düzenlenen Moskova Çevre Eğitimi Konferansı (1987), Selanik Uluslararası Çevre ve Toplum Konferansı (1997), Ahmedabad Çevre Eğitimi Konferansı (2007) adlı konferanslarda değiştirilmemiş, çevre eğitimi anlayışı sürdürülebilir kalkınma eğitimine dönüştürülmüş̧ür.

1987 yılında yayınlanan Brundtland Raporu'nda sürdürülebilirlik kavramı tanımlanmış, toplumun her kesiminin sürdürülebilir kalkınma sürecinde aktif rol oynaması gerektiği belirtilmiştir (Han \& Kaya, 2012; Karabıçak \& Özdemir, 2015). 1992 yılında Rio Konferansı, UNESCO'nun 2004 ile 2015 seneleri arasını kapsayan Sürdürülebilir Kalkınma İçin Eğitimin On Yılı adlı raporu, 2002'de yayınlanan Maastricht Küresel Eğitim Bildirgesi, 2007 yılında Avrupa Kalkınma Mutabakatı ve 2015 'te Birleşmiş Milletler Kurulu'nda sürdürülebilir kalkınma eğitiminin gerekliliği belirtilmiştir (Carvalho da Silva, 2008). Türkiye'de çevreye yönelik ilgi uluslararası gelişmelerle paralellik göstererek 1970'lerde başlamış, çevre hakkı anayasaya 1982'de dâhil olmuştur. 1982'den itibaren Çevre Bakanlığı'nın yönetmeliklerinde, 3., 4., 6., 7., 9., 10. ve 11. beş yıllık kalkınma planlarında (DPT), AB Entegre Çevre Uyum Stratejisi (2007-2023) ile uyumlanma ilkelerinin içinde toplumda çevre farkındalığının artması ve basın-yayın organlarılya eğitimler düzenlenmesi gibi kararlar mevcuttur (Ertürk, 2018).

Çevreye duyarlı bir toplum oluşturabilmek için bu konuda eğitim şarttır. Çevre eğitimi, yaşam boyu eğitim şeklinde devam ettirilmeli ve örgün eğitimin yanı sıra yaygın eğitimde de ele alınmalıdır. Ayrıca bu eğitim seçmeli olarak kalmamalı, zorunlu hale getirilmelidir. Çevre eğitimine katkı sağlamak için bazı ülkelerde eko-okul gibi uygulamalara yer verilmektedir.

AB'ye üye olan ülkelere rehber olması amacıyla Çevre Eylem Programları oluşturulmuştur. Bu programlar, AB'ye üye olan ülkeler dişında aday ülkeler ve başka ülkeler tarafından da örnek alınmıştır (Aydın \& Çamur, 2017).

Bulgaristan ve Finlandiya'da 1970'lerden önce de belirgin olarak çevre eğitimine yönelik uygulamalar mevcuttur (Tablo 2 ve 3 ).

Uluslararası gelişmelere paralel olarak çevre eğitimi, sürdürülebilir kalkınma eğitimine dönüştürülmüştür. Türkiye, Almanya, İngiltere, Rusya, Slovakya, Bulgaristan, Tanzanya, Bhutan, Malezya, Endonezya, Hong Kong, Çin, ABD, Brezilya, Avustralya gibi bazı ülkelerde sürdürülebilirliğin ön planda tutulduğu gözlenmektedir (Tablo 2 ve 3). Örneğin; Türkiye'de geleneksel çevre eğitiminin yetersiz kaldığı düşünüldüğü için sürdürülebilir gelişme amaçlı eğitime geçilmesi gerektiği belirtilmektedir (Özdemir, 2007). Filipinler'de ise Sürdürülebilir Kalkınma Eğitimi mevcuttur fakat bu eğitim tek başına ele alınmamakta olup kültürel gelişmeye dayalı eğitime de önem verilmektedir. Ayrıca Filipinler, Sürdürülebilir Kalkınma Eğitimi'ni ilerleyen yıllarda zorunlu hale getirmeyi amaçlamakta ve bu konu hakkında proje yarışmaları düzenlemeyi hedeflemektedir (Chandran et al., 2017).

Türkiye, Almanya, Finlandiya, Bhutan ve Çin gibi bazı ülkelerde Eko-Okul (Yeşil Okul) uygulamaları mevcuttur. Uygulama dışında ayrıca doğa eğitim kampları ve doğa gezileri de düzenlenmektedir. Bazı ülkelerde ise maalesef bu uygulamalar yer almamaktadır. Türkiye, Almanya, İngiltere, Finlandiya, Bulgaristan, Botsvana, Bhutan vb. ülkelerde açık alan (sınıf dışı) etkinliklere yer verilmektedir (Tablo 2 ve 3). Ayrıca Finlandiya'da bu etkinlikler müfredata uygun hale getirilmiştir (Özdemir, 2017).

Hong Kong (Lee, 1997) ve Çin'de (Lee \& Tilbury, 1998) öğretmenlere hizmet içi eğitim verilerek çevre farkındalığı kazandırmak amaçlanmaktadır. İngiltere (Glackin \& King, 2018), Finlandiya (Özdemir, 2017), Filipinler, Slovakya (Chandran et al., 2017) ve Avustralya (Okur, 2012) öğretmenlerin eğitimine önem veren diğer ülkelerden bazılarıdır. Azerbaycan (Kadimbeyli, 2014), Ekvador (Ahi \& Kahriman Pamuk, 2019; Encalada, 2003) ve Avustralya'da (Okur, 2012) toplum eğitimine önem verilmiş ve halkı bilinçlendirmek amacıyla çeşitli projeler düzenlenmiştir. 
Özbekistan'da ise toplumun bilinçlendirildiği ve bu konuda söz sahibi olduğu gözlemlenmiştir (Aliyev, 2013). Ayrıca toplumu bilinçlendirme amacıyla bazı ülkelerde yetişkinler için çevre eğitimi uygulamaları düzenlenmektedir. Almanya (Bolscho \& Haunschild, 2006) ve Çin (Lee \& Tilbury, 1998; State Environmental Protection Bureau Propaganda and Education, 1991) bu ülkelere örnektir. Bulgaristan'da ise aileler de (ağaç dikmek gibi faaliyetler ile) eğitime dâhil edilmektedir (Soykan vd., 2012).

Türkiye'de çevre eğitimi seçmeli ders olarak yer almakta olup zorunlu tutulmamakta (Akçay, 2006), üniversitelerde ise lisans programlarının türlerine göre zorunlu ya da seçmeli olarak okutulmaktadır (Çabuk, 2019; Türkiye Cumhuriyeti Yüksek Öğretim Kurumu, 2018). Finlandiya, Çin ve Azerbaycan'da çevre eğitiminin ilköğretimde zorunlu tutulması diğer ülkelere göre olumlu yönde farklılık göstermektedir. Filipinler detaylı çevre eğitimi politikası ve çevre eğitimi uygulamalarıyla dikkat çekmektedir. Ülkelerde çevre eğitimi örgün eğitimde genellikle çok disiplinli olarak uygulanmaktadır. Türkiye, Almanya, Rusya, Slovakya, Bulgaristan, Tanzanya, Güney Kore, Bhutan, Hong Kong, Çin ve Kanada vb. bazı ülkelerde çevre ile ilgili konulara çok disiplinli eğitim yöntemiyle yer verilmektedir (Tablo 2 ve 3 ).

Afrika ülkelerinden Güney Afrika ve Tanzanya'da diğer ülkelere nazaran daha detaylı çevre eğitimi uygulamaları mevcuttur (Tablo 2). Botsvana'da da çevre eğitimine yönelik uygulamalar ve araştırmalar mevcuttur (Obol et al., 2003). Güney Kore'de Yeşil Büyüme’ye yönelik eğitimde düzenlemeler yapılmıştır (Ahi \& Kahriman Pamuk, 2019). Yaşam Boyu Öğrenme Yasası mevcuttur (Erdik, 2016). Asya ülkelerinde çevre eğitimi yaygın eğitimle desteklenmektedir (Tablo 2). Filipinler'de çevre eğitiminin örgün eğitimin yanı sıra yaygın eğitimde de verilmesi gerektiği belirtilmekte, yaşam boyu öğrenme boyutuna çıkarılması amaçlanmaktadır (Chandran et al., 2017). Kazakistan'da ekolojik güvenliği sağlamak ön plandadır (Aliyev, 2013).

ABD'de çevre eğitiminin çevre dernekleri tarafından 1970'lerden önce başladığ 1 NAEE gibi kuruluşların yaygın ve etkili çevre eğitimi faaliyetleri bulunduğu bilinmektedir (Ahi \& Kahriman Pamuk, 2019). Bu kurumların Kanada'da işbirlikleri bulunmakta olup, çevre eğitimi uygulamalarında hem uluslararası gelişmeler takip edilmiş hem de ABD'den etkilenilmiştir. Kanada'da çevre eğitimi politikaları bireysel girişim ile başlayıp sonradan hükümet politikalarında yer almıştır (Hart, 1990). Kanada'da Amerika'daki uygulamalar örnek alınırken, Özbekistan'ın çevre eğitimi politikalarına yaklaşımı kendilerine hastır (Aliyev, 2013). Çin'de ise çevre politikası ve çevre eğitimi politikası paralel olarak ilerlemektedir (Lee \& Tilbury, 1998; State Environmental Protection Bureau Propaganda and Education, 1991). Brezilya'da çevre için kamu politikaları düzenlenmiştir. Genelde hükümetler çevre konusunda duyarlıdır. İngiltere, ABD, Kanada, Yunanistan, Güney Afrika, Bhutan, Hong Kong, Çin, Özbekistan, Kazakistan, Azerbaycan, Avustralya, Ekvador, Filipinler ve Brezilya gibi bazı ülkelerde çevre eğitimine hükümet tarafından destek sağlanmaktadır (Tablo 2). Ekvador'da ise çevre eğitiminde hükümet merkezde olmamasına rağmen bu konuda destekleri mevcuttur (Ahi \& Kahriman Pamuk, 2019; Encalada, 2003). Hükümetin yanı sıra bazı ülkelerde sivil toplum kuruluşları, bireysel kurumlar ve medya tarafından da destekler sağlandığı görülmektedir. Avrupa ülkelerine bakıldığında genelde çevre eğitiminin STK, çevre dernekleri ve medya ile desteklendiği görülmektedir (Tablo 2). Örneğin; Almanya'da, sivil toplum kuruluşları okullarla işbirliği içinde çalışmakta ve çeşitli dernekler bu konuda katkı sağlamaktadır (Bolscho \& Hauenschild, 2006). Yine baktığımızda Bulgaristan, Botsvana, Bhutan, Endonezya, Filipinler, Hong Kong, Çin, Kazakistan, Ekvador, Brezilya, Papua Yeni Gine ve Avustralya'da da bu konuda katkı sağlandığı görülmektedir (Tablo 2 ve 3). ABD'de Çevre Koruma Ajansı, Eğitim Bakanlığı ve Eğitim Federal Teşkilat Komitesi ile birlikte çeşitli faaliyetler düzenlemektedir. Papua Yeni Gine'de gönüllü eğitim ekipleri çevre hakkında bilinçlendirme amaçlı okul ziyaretleri yapmaktadırlar (Ahi \& Kahriman Pamuk, 2019).

Çevre eğitimi genel olarak yaygın eğitimle desteklenmektedir. Çevre eğitimi uygulamaları çoğu ülkede çevreye yönelik ilginin uluslararası boyuta taşındığı 1970'li yıllarda başlamıştır. 
Avrupa, Asya ve Amerika ülkelerinde yoğun olmakla birlikte birçok ülkede eko-okul uygulaması mevcuttur. İncelenen ülkelerin yarısında çevre eğitimine yönelik özel politikalar geliştirilmiştir. Çevre Eğitimi dersinin disiplinler arası olarak Tanzanya, Rusya, Türkiye ve Filipinlerde uygulandığı, zorunlu bir ders olarak sadece Filipinler'de bulunduğu saptanmış, çevre eğitiminin dünya çapında çok disiplinli olarak uygulandığı görülmüştür (Tablo 2 ve 3).

Çevreyi koruma farkındalığının uluslararası boyuta taşındığı dönemlerde kayda değer bir ilerleme sağlanırken, günümüzde varılan nokta, dünyanın farklı bölgelerinde artan çevre sorunlarının mevcudiyetiyle çevre politikalarının yetersiz kaldığını gözler önüne sermektedir. $\mathrm{Bu}$ gerçekleri göz önüne alınca artan çevre sorunlarına karşın mevcut çevre koruma politikalarının geliştirilmesi gerektiği görülmektedir. Mevcut çevre politikası ilkelerinden ihtiyatlılık, kirleten öder gibi ilkeler göz önünde bulundurularak üretilecek olan politikalar çevre korumanın temel prensiplerinden biri olan bugün ile birlikte yarını da düşünerek hareket etmemizi sağlayacaktır. Bizden sonra gelecek olan nesillere ve tüm canl1, cansız unsurlara temiz bir gelecek ve temiz bir doğa bırakmak için var olan çevre politikalarımızı ve dolayısıyla çevre eğitimi politikalarımızı geliştirmemiz gerektiği çok nettir.

Çevre eğitimi ne kadar sürdürülebilir kalkınma eğitimi olarak tanımlanmış olsa da dünya genelinde ekonomi politikalarıyla çevre eğitimi politikalarının çatışmakta olduğu görülmektedir. Ülkelerin aradaki dengeyi kurmak için üretim ve tüketim faaliyetlerinde değişimler yapması şarttır.

Türkiye'den örnek verirsek; kapatılması gereken kömürle çalışan termik santraller, altın madeni ocakları, otel, villa, sanayi tesisi vb. yapımı için tahrip edilen ormanlık alan ve tarım arazileri, Marmara Denizi ekosisteminin evsel, tarımsal ve sanayi atıkları nedeniyle ölmek üzere olması gibi güncel çevre sorunları çevre eğitimi politikalarının diğer politikalarla ve uygulamalarla desteklenmeden çözülemeyeceği gerçeğinin açık bir kanıtıdır.

\section{Öneriler}

Yukarıda yer alan değerlendirmelerin 1şığında dünyada ve Türkiye'de ideal bir çevre eğitimi ve politikasının nasıl olması gerektiği konusundaki önerilerimiz aşağıdadır:

*Ülkelerin çevre eğitimi programları anayasada ve yönetmeliklerde yer almalıdır.

*Çevre (doğal ortam) tüm insanlığın ihtiyacını karşıladığı için, çevrenin korunması da tüm insanlığın sorumluluğundadır. Bu nedenle öğretim süreçlerinde çevre eğitimi ulaşılması gereken akademik hedefler topluluğu olarak değil, bir insanlık görevi olarak verilmelidir. Ülkelere ait öğretim programlarında çevre eğitimi dersleri zorunlu ders olarak bulunmalıdır.

*Bu programlarda açık hava etkinliklerine yer verilmelidir.

*Çevre eğitimi sadece canlı unsurları, doğal kaynakları korumaya yönelik değil; cansız unsurları da (doğal ortam özellikleri, kültür gibi) kapsamalıdır.

*Çevre Eğitimi müfredat1, okul öncesi, ilkokul, ortaokul, lise ve üniversite öğretim programlarında sarmal bir şekilde birbiriyle bağlantılı ve tamamlayıcı olmalıdır. $\mathrm{Bu}$ şekilde, verilecek çevre eğitimi derslerinde bir süreklilik sağlanmış olacaktır.

*Ülkelerin çevre eğitim politikalarına yön veren yasalarda, kararname ve diğer belgelerde çevre dostu davranış kazandırmaya yönelik etkinlikler ile 'Waldorf, Reggio Emilia, Montessori, Orman Okulları, Özgür Okullar (Summerhill Okulu), Demokratik Okul, Eleştirel Pedagoji, Sudbury Valley Okulları, Ev Okulları, Pikler Yaklaşımı' vb. gibi zenginleştirilmiş yaklaşımlara yer verilmelidir. Söz konusu alternatif yaklaşımlara göre şekillenecek çevre eğitimi, kamu-özel ayrımı yapılmaksızın bütün öğretim kurumlarında uygulanmalı ve ücretsiz olmalıdır.

*Gerçekleştirilecek olan çevre eğitimi politikaları, doğal ve kültürel miras değerlerinin korunmasını önemsemelidir. 
*Bütün üniversitelerin birinci sınıflarında 'Çevre ve Afet Eğitimi' dersi zorunlu olmalıdır.

*Ülkelerin milli gelirlerinden çevre eğitimine ayırılan bütçe arttırılmalıdır.

*Çevre eğitimi dersleri alanında uzman kişiler tarafından verilmelidir. Bunun yanında çevre eğitimi, öğretimin her aşamasında eğitimci tarafından uygun konularla ilişkilendirilerek verilmelidir (Erten, 2001).

*Okul yöneticileri ve öğretmenlere branş fark etmeksizin çevre eğitimi konusunda hizmet içi eğitim uygulanmalıdır.

*Bütün eğitim öğretim kurumlarında çevre eğitimiyle ilgili seminerler, konferanslar düzenlenmeli ve düzenlenen bu tür etkinlikler halka açık şekilde yürütülmelidir.

*Örgün eğitim yanında halkın çevre bilincinin arttırılması için çevre eğitimi politikaları çerçevesinde yaygın eğitime (yetişkinler için) özel bir önem verilmelidir.

*Çevre eğitimi politikaları belirlenirken hızlı yaşam ve tüketime karşı, yavaş yaşam yavaş tüketim (slow food, slow life, citta slow) uygulamaları dikkate alınmalı ve bu unsurlar 1şığında çevre eğitimi politikaları belirlenmelidir. Başka bir deyişle yerel değerler gözetilmeli ve bu değerlerin çerçevesinde bir çevre eğitimi politikası üretilmelidir.

*Çevre eğitimi politikaları yerelden evrensele doğru şekillenmelidir.

*Çevre eğitimi politikaları yürütülürken bu yolda sivil toplum kuruluşlarına büyük pay düşmektedir. Bu sebeple sivil toplum kuruluşlarının çevre eğitimi konusunda daha aktif bir yol izlemeleri gerekmektedir.

*Siyasi partilerin parti programlarında çevre eğitimi politikalarına teori-pratik çerçevesinde yer verilmelidir.

*Türkiye'de ve diğer ülkelerde ivedilikle eğitim bakanlıkları ve üniversiteler işbirliğiyle eğitimciler, öğrenciler, veliler, çevre eğitimiyle-çevre politikalarıyla ilgili çalışmalarda bulunan akademisyenler, çevreyle ilgili sivil toplum kuruluşları vb. ile istişare edilerek ideal bir çevre eğitimi politikası oluşturulması çalışmalarına başlanmalıdır.

*Çevre eğitimi ile ilgili alınan kararlar kâğıt üzerinde kalmamalı, uygulamaya geçirilmelidir.

*Gelir adaletsizliği minimuma indirilerek, çevre tahribatının önüne geçilmelidir.

*Ülkelerin kalkınma politikaları çevre tahribatı yok sayılarak oluşturulmamalı, mümkün olabilecek en dengeli sistem benimsenmeli ve hayata geçirilmelidir.

*Basın yayın organlarında çevre eğitimine ve çevre koruma bilincine yönelik yayınlar zorunlu olmalidır.

*Halka açık alanlarda ve bina içlerinde görünen yerlerde çevre eğitimi ile ilgili panolar, afişler, objeler vb. yerleştirilmelidir ve toplumun ilgisini üzerine çekecek çevre eğitimi konulu etkinlikler yapılmalıdır.

*Teknolojinin ilerlemesi yolunda AR-GE çalışmaları desteklenirken çevre eğitimi ve politikaları gözetilmeli, teknolojik gelişim çevreye uyumlu bir şekilde ilerlemeli ve sürdürülebilir kalkınma teknolojileri (yeşil teknoloji gibi) geliştirilmelidir.

*Çevre eğitimi alanında ülkeler arasında işbirlikleri oluşturulmalı ve sürekliliği sağlanmalıdır.

*Hazırlanacak olan ve mevcut çevre eğitimi programları kalkınma planlarında yer almalidir.

www.turkishstudies.net/turkishstudies 
1540 Ali Ekber Gülersoy - Hilal Yener - Tuğçe Turgut - Dilay Melis Özşahin - Deniz Anter...

*Ülkelerin kalkınma politikaları koruma-kullanma dengesini dikkate alarak şekillenmeli ve sürdürülebilir kalkınma-çevre ilişkisi dengesi sağlanmalıdır.

*Çevre eğitimi uluslararası alanlarda daha fazla desteklenmelidir. UNEP (Birleşmiş Milletler Çevre Programı) ve IEEP (Uluslararası Çevre Eğitimi Programı) gibi büyük kuruluşlar çevre eğitimi konusunda daha aktif rol oynamalıdır.

*Uluslararası alternatif çevre kurum, kuruluşları ve hareketleri $\left(\mathrm{WWF}^{2}, \mathrm{IUCN}^{3}\right.$, Ekta Parishad, Uluslararası La Via Campesina Ağı (Çiftçilerin Yolu), Topraksızlar Hareketi (MST) vb.) arasında çevre eğitim politikaları çerçevesinde işbirliği sağlanmalıdır".

*Özetle insan ve doğal unsurlar arasındaki ilişki sürdürülebilir bir çevre eğitimi politikas1 çerçevesinde şekillendirilmelidir. Bunun için doğadan yararlanmamaktan ziyade koruyarak kullanma yöntemleri önemsenmeli, yeşil teknolojiler desteklenmelidir.

*Bu çalışmanın çevre eğitimi politikaları alanında yapılacak araştırmalara esin kaynağı olması temennimizdir. Söz konusu çerçevede ülke ölçeğinde çevre eğitim politikaları çalışmaları yap1labilir.

\section{Kaynakça}

Ahi, B \& Kahriman Pamuk, D. (2019). Toplum, aile ve çevre eğitimi ilişkileri: çeşitli ülkelerde erken çocukluk dönemi çevre eğitimi yaklaşımları. Kahriman Pamuk D. (Der.), Erken Çocukluk Döneminde Çevre Eğitimi ve Sürdürülebilirlik, ss. 89-118. Ankara: An1 Yayıncilik.

Ajiboye, J. O. \& Silo, N. (2008), Enhancing Botswana Children's environmental knowledge. Attitudes And Practices Through The School Civic Clubs. International Journal of Environmental \& Science Education, 3(3), 105-114.

Akçay, İ. (2006). Farkl ülkelerde okul öncesi öğrencilerine yönelik çevre eğitimi. [Yayımlanmamış Yüksek Lisans Tezi], Uludağ Üniversitesi Sosyal Bilimler Enstitüsü.

Akgül, U. (2013). Eylem Antropolojisinin bileşenleri olarak ÇED ve SED. Antropoloji, (25), 47-64

Aktepe, S. \& Girgin, S. (2009). İlköğretimde Eko-Okullar ve klasik okulların çevre eğitimi açısından karşılaştırılması. İlkögretim Online, 8(2). 401-414.

Alım, M. (2006). Avrupa Birliği üyelik sürecinde Türkiye'de çevre ve ilköğretimde çevre eğitimi, Kastamonu Eğitim Dergisi, 14 (2), 599-616.

Aliyev, E. (2013). Rusya ve Türk dünyası ülkelerinin çevre politikalarının karşılaştırmalı analizi, ss. 79-82, Uluslararası Türk Dünyası Çevre Sorunları Sempozyumu ve "Tıbbi Bitkiler Sergisi" Bildiriler Kitabl.

Allen, I., Chiotha, S., Kalowekamo, F. \& Trudel, M. (1996), National environmental education and communication strategy, 1996-1999. Lilongwe, Malawi: Ministry of Research and Environmental Affairs.

Allen, R. (1980). How to save the world: strategy for world conservation. England: MCCorquodale (Newton) Ltd.

\footnotetext{
2 Doğal Hayatı Koruma Vakfi.

${ }^{3}$ Uluslararası Doğayı Koruma Birliği.

${ }^{4}$ Bakınız: Gülersoy, A.E. (2019). İnsan-Doğa İlişkiselliğinde Sürdürülebilirliğin Yeniden Düşünülmesi. M. Kahyaoğlu \& N. Özgen (Ed.), Sürdürülebilir Kalkınma içinde (s. 302-337). Ankara: Pegem Akademi Yayıncılık.
} 
Arat, G., Türkeş, M. \& Saner, E. (2002). Vizyon 2023: Bilim ve teknoloji stratejileri teknoloji öngörü projesi- Çevre ve sürdürülebilir kalkınma paneli- Uluslararası sözleşmeler ön rapor. Ankara: TÜBITTAK.

Artun, H. \& Bakırcı, H. (2012). Ülkelerin çevre eğitimine etki eden faktörlerin değerlendirilmesi. Kastamonu Eğitim Dergisi, 2(20), 365-384.

Aydın, A. H. \& Çamur, Ö. (2017). Avrupa Birliği Çevre Politikaları ve Çevre Eylem Programları Üzerine Bir İnceleme. Bingöl Üniversitesi Sosyal Bilimler Enstitüsü Dergisi, 7(13), 21-44.

Bakırcı, H. \& Artun, H. (2011). Farklı ülkelerin çevre eğitimi politikalarını karşılaştırmaya yönelik bir durum çalışmasi. Electronic Journal of Social Sciences, 10(37), 202-223.

Baykal, H. ve Baykal, T. (2008). Küreselleşen Dünya'da çevre sorunları/environmental problems in a globalized world. Mustafa Kemal Üniversitesi Sosyal Bilimler Enstitüsü Dergisi, 5(9), 117.

Baykan, A. R. (Ed.) (2004), Türkiye Çevre Atlası. Ankara: Çevre Envanteri Dairesi Başkanlığı. Ve Planlama Genel Müdürlüğü Çevre Envanteri Dairesi Başkanlığı.

Bayram, T., Altıkat, A. \& Torun, F. (2011). Avrupa Birliği ve Türkiye'de çevre politikaları. I $\breve{g} d ı r$ Üniversitesi Fen Bilimleri Enstitüsü Dergisi, 1(1), 33-38.

Bocakova, O. \& Kubickova, D. (2015). Education in the 21st century. International Journal for Innovation Education and Research, 3(2), 160-169.

Bolscho, D. \& Hauenschild, K. (2006). From environmental education to education for sustainable development in Germany, Environmental Education Research, 12(1), 7-18.

Boulton, M. \& Eddershaw, J. (Ed.). (1997). Pan-African wildlife clubs resource book. International Centre for Conservation Education, Cheltenham, United Kingdom.

Bozkurt, O. \& Cansüngü Koray, Ö. (2002). İlköğretim Öğrencilerinin Çevre Eğitiminde Sera Etkisi İle İlgili Kavram Yanılgıları, Hacettepe Üniversitesi Eğitim Fakültesi Dergisi, 23, 67-73.

Budak, S. (2000). Avrupa Birliği ve Türk çevre politikası. İstanbul: Büke Yayınları.

Budak, S. (2021). Çevre Politikası ve Hukuku. İstanbul Üniversitesi Açık ve Uzaktan Eğitim Fakültesi Kamu Yönetimi Lisans Program. http://auzefkitap.istanbul.edu.tr/kitap/kamuy\%C3\%B6netimi_ue/cevrepolvehuk.pdf

Bulut, M. (2015). Ortaöğretim ögrencilerinin çevresel risk algisl, tutum ve bilgi düzeylerinin belirlenmesi üzerine bir çalışma. [Yayımlanmamış Yüksek Lisans Tezi]. Niğde Üniversitesi Sosyal Bilimler Enstitüsü.

Bulut, S. (2008). Türkiye'de yerel yönetimlerin çevre politikası uygulamalarının değerlendirilmesi. [Yayımlanmamış Yüksek Lisans Tezi]. Ankara Üniversitesi Fen Bilimleri Enstitüsü.

Carvalho da Silva, M. (Ed.). (2008). Küresel eğitim rehberi küresel eğitimi anlamak ve uygulamak üzere eğitimciler için el kitabı. Lizbon: Avrupa Konseyi Kuzey-Güney Merkezi tarafindan yayımlanmıştır.

Carvalho, I. C. D. M. \& Frizzo, T. C. E. (2016). Environmental Education in Brazil. Peters, M., (Ed.). In Encyclopedia of Educational Philosophy and Theory. Springer: Singapore.

Centro de Análisis de Políticas Públicas. (CAPP). (2013). Informe País: Estado del Medio Ambiente en Chile 2012. Universidad de Chile, Santiago de Chile. 
1542 Ali Ekber Gülersoy - Hilal Yener - Tuğçe Turgut - Dilay Melis Özşahin - Deniz Anter...

Chandran, R., Gunawardena C. \& Castro, N. (2017), The National Environmental Education Action Plan 2018-2040 (Version 1). Quezon City: Department of Environment and Natural Resources, The Republic of the Philippines.

Chen, L. \& Sun, D. (2009). Theory and practice of education for ecological civilization in China. Beijing: Central Compilation and Translation Press.

Chinese Society for Environmental Sciences (CSES). (2008). The history of Chinese Society for environmental sciences. Shanghai: Shanghai Jiotong University Press.

Commission of the European Communities (COM), (2001). A Sustainable Europe for a Better World: A European Union Strategy for Sustainable Development Communication From The Commission. Brussels.

Çabuk, B. (2019). Çevre eğitimi. Kahriman Pamuk D. (Der.), (1. Bask1), Erken Çocukluk Döneminde Çevre Eğitimi ve Sürdürülebilirlik. ss. 1-38 Ankara: Anı Yayınc1lık.

Çalık, M. (2009). Environmental education in context, an international perspective on the development of environmental education. Sense Publishers: Rotterdam, Boston, 109-122.

Çelikbaş, A. (2016). Sürdürülebilirliği temel alan çevre eğitiminin ortaokul ögrrencilerinin çevresel davranışlarına ve sürdürülebilir çevre tutumlarına etkisi. [Yayımlanmamış Yüksek Lisans Tezi]. Mersin Üniversitesi Eğitim Bilimleri Enstitüsü Fen Bilgisi Eğitimi Bilim Dalı.

Çokgezen, J. (2007). Avrupa Birliği çevre politikası ve Türkiye. Marmara Üniversitesi İktisadi ve İdari Bilimler Fakültesi Dergisi, 23(2), 91-115.

Çolakoğlu, E. (2010). Haklar söyleminde çevre eğitiminin yeri ve Türkiye'de çevre eğitiminin anayasal dayanakları. Türkiye Barolar Birliği Dergisi, 88, 151-171.

De Haan, G. \& Harenberg, D. (1999). Bildung für einenachhaltige Entwicklung: "Förderprogramm Bildung für nachhaltige Entwicklung". Freie Universität Berlin: http://www.blkbonn.de/papers/heft72.pdf

Demir, E. \& Yalçın, H. (2014). Türkiye'de çevre eğitimi. Türk Bilimsel Derlemeler Dergisi, 7(2), 07-18.

Department of Education (Northern Ireland) (2001). Department for Education and Employment and Office for Education Departmental Report (DFEE). https://www.gov.uk/government/publications/department-for-education-and-employmentand-office-for-standards-in-education-departmental-report

Doğan, M. (1997). Ulusal Çevre Eylem Planı: Eğitim ve Katılım. Türkiye Çevre Vakfı.

Duru, B. (2007). Avrupa birliği çevre politikası. Erhan, Ç. ve Senemoğlu, D. (Der). Avrupa Birliği Politikaları. Ankara: İmaj Yayınevi.

Economic Planning Unit (EPU). (2016). The national SCP Blueprint 2016-2030. Prime Minister's Department, Federal Government Administrative Centre, Malaysia.

Egeli, G. (1996). Avrupa Birliği ve Türkiye'de çevre politikaları. Türk Çevre Vakfı Yayını, Ankara.

Encalada, M. A. (2003). Ecuador. In Environmental Education in 21th Century. Palmer, J. A. (Ed.). New York: Routledge.

Erdik, E. (2016), Güney Kore'de Üstün Zekâlılar Eğitimi ve Han Nehri Mucizesi: Gezi Notları. Journal of Gifted Education and Creativity, 3(2), 1-67. 
Ergün, A. G. M. (1997). Azerbaycan Eğitim Sistemi. Kuram ve Uygulamada Eğitim Yönetimi Dergisi. 12(12), 499-514.

Erten, S. (2001). Çevre eğitiminde planlanmış davranış teorisinin kullanılması. Hacettepe Üniversitesi Ë̆itim Fakültesi Dergisi, 20 (20), 73-79.

Erten, S. (2003). 5. sınıf öğrencilerinde "çöplerin azaltılması" bilincinin kazandırılmasına yönelik bir öğretim modeli. Hacettepe Üniversitesi Eğitim Fakültesi Dergisi, 25, 94-103.

Erten, S. (2004). Çevre eğitimi ve çevre bilinci nedir, çevre eğitimi nasıl olmalıdır. Çevre ve İnsan Dergisi, 65(66), 1-13.

Erten, S. (2005). Okul öncesi öğretmen adaylarında çevre dostu davranışların araştırılması. Hacettepe Üniversitesi Ë̆itim Fakültesi Dergisi, 28(28), 91-100.

Erten, S. (2012). Türk ve Azeri öğretmen adaylarında çevre bilinci. Eğitim ve Bilim, 37(166), 88100.

Ertürk, H. (2009). Çevre Bilimleri. Bursa: Ekin Basım Yayın Dağıtım.

Ertürk, H. (2018). Çevre Politikaları. Bursa: Ekin Yayınevi.

Ertürk, S. (1975). Eğitimde program geliştirme. Ankara: Yelkentepe Yayınları.

Ertürk, S. (1998). Eğitimde program geliştirme. Ankara: Meteksan A.Ş.

Garner, L.H. (2002). Education for the twenty-first century: Leadership for globalization. Lowa: Second Korea-U.S. Forum.

Glackin, M. A. \& King, H. (2018). Understanding environmental education in secondary schools in England: report 1: perspectives from policy. In King's College London.

Glasson, G. E., Frykholm, J. A., Mhango, N. A., \& Phiri, A. D. (2006). Understanding the earth systems of Malawi: Ecological sustainability, culture, and place-based education. Science Education, 90(4), 660-680.

Gonçalves, C. W. (2001). Geo-grafías: movimientos sociales, nuevas territorialidades y sustentabilidad. México: Siglo XXI.

González Gaudiano, E. (1997). Educación Ambiental. Historia y Conceptos a veinte años de Tbilisi. México D. F.: Sistemas Técnicos de Edición.

González Gaudiano, E. (1998). Centro y periferia en educación ambiental: Un enfoque antiesencialista. México D. F.: Mundi-Prensa.

Gökdağ, D. (1994). Ortaöğretim programında çevre, Cogito, 2, 47-50.

Gökmen, A., Solak, K. \& Ekici, G. (2019). Eğitim ve sürdürülebilirlik. Kahyaoğlu, M. ve Özgen, N. (Der.), Sürdürülebilir Kalkınma içinde ss. 72-89. Ankara: Pegem Akademi.

Görmez, K. (2007). Çevre Sorunları. Ankara: Nobel Yayınları.

Güler, T. (2009). Ekoloji temelli bir çevre eğitiminin öğretmenlerin çevre eğitimine karş1 görüşlerine etkileri. Ĕgitim ve Bilim, 34(151), 30-43.

Gülersoy, A. E., Dülger, İ., Dursun, E., Ay, D. \& Duyal, D. (2020). Nasıl Bir Çevre Eğitimi? Çağdaş Yaklaşımlar Çerçevesinde Bazı Öneriler. Turkish Studies, 15(5), 2357-2398.

Gülersoy, A. E. (2019). İnsan-Doğa İlişkiselliğinde Sürdürülebilirliğin Yeniden Düşünülmesi. Kahyaoğlu, M. \& Özgen, N. (Der.), Sürdürülebilir Kalkınma içinde ss. 302-337. Ankara: Pegem Akademi Yayıncılık. 
1544 Ali Ekber Gülersoy - Hilal Yener - Tuğçe Turgut - Dilay Melis Özşahin - Deniz Anter...

Gülsoy Kerimoğlu, P. N. (2019). Türkiye ve Güney Kore Eğitim Sistemlerinin Karşılaştırmalı Olarak Incelenmesi Hacettepe Üniversitesi. [Yayımlanmamış Yüksek lisans tezi]. Hacettepe Üniversitesi, Eğitim Bilimleri Enstitüsü.

Haktanır, G. \& Çabuk, B. (2000). Okulöncesi dönemindeki çocukların çevre algıları. IV. Fen Bilimleri Eğitimi Kongresi Bildiri Kitabı, ss. 76-82. Hacettepe, Ankara.

Ham, S.H. \& Sewing, D.R. (1988). Barriers To Environmental Education. Journal of Environmental Education, 19(2), 17-24.

Han, E. \& Kaya, A. A. (2012). Kalkınma ekonomisi, teori ve politika. Ankara: Nobel Yayınevi.

Hart, P. (1990). Environmental Education in Canada: Contemporary Issues \& Future Possibilities. Australian Journal of Environmental Education, 6, 45-65.

Hart, P. (2003). Canada. In Environmental Education in 21th Century. Palmer, J.A (Ed.). New York: Routledge.

Hergüner, B. \& Kalkan, E. (Ed.) (2018). Türkiye'de çevre politikaları. Ankara: Nobel Akademik Yayınc1lik.

Hey, C. (2005). A short history of the policy strategies. Eu Environmental Policies Handbook. European Environmental Bureau. Brussels.

Huaixin, Z. (2003). The People's Republic of China. In Environmental Education in 21th Century. Palmer, J.A (Ed.). New York: Routledge.

Hungerford, H. R. \& Peyton, R. B. (1986). Procedures for Developing an Environmental Education Curriculum. A Discussion Guide for UNESCO Training Seminars on Environmental Education. Environmental Educational Series 22. Paris: Boudin.

Irwin, P. \& Lotz - Sisitka, H. (2005). A history of environmental education in South Africa. In Loubser, C. P. (Ed.). Environmental education: Some South African perspectives, p. 35-56. Pretoria: Van Schaicks.

Jacobson, S.K. \& Mcduff, M.D. (1998). Conservation education. In Sutherland, W.J. (Ed.) Conservation Science and Action, p. 237-255. Oxford: Blackwell Science.

Jeronen, E., Jeronen, J. \& Raustia, H. (2009). Environmental education in Finland-A Case Study of Environmental Education in Nature Schools. International Journal of Environmental and Science Education, 4(1), 1-23.

Kadimbeyli, M. (2014), Azerbaycan folklorunda ekolojik eğitim (Nahçıvan materialları üzere), 21. Yüzyılda Eğitim ve Toplum Eğitim Bilimleri ve Sosyal Araştırmalar Dergisi, 2(4), 161-178.

Karabıçak, M. \& Özdemir, M. B. (2015). Sürdürülebilir kalkınmanın kavramsal temelleri. Süleyman Demirel Üniversitesi Vizyoner Dergisi, 6(13), 44-49.

Karacan, A. R. (2007). Çevre ekonomisi ve politikası. İzmir: Ege Üniversitesi Yayınları.

Karasar, N. (1999). Bilimsel araştırma yöntemi: kavramlar, ilkeler, teknikler. (8. bask1). Ankara: Nobel Yayın Dağıtım.

Karataş, A. \& Aslan, G. (2012). İlköğretim öğrencilerine çevre bilincinin kazandırılmasında çevre eğitiminin rolü: Ekoloji temelli yaz kamp1 projesi örneği. Zeitschrift für die Welt der Türken/Journal of World of Turks, 4(2), 259-276.

Karataş, A. \& Karabağ, Ö. (2013). Cittaslow hareketinde çevre eğitiminin önemi. Balıkesir Üniversitesi Sosyal Bilimler Enstitüsü Dergisi, 16(29) , 1-21. 
Karrow, D. D. \& Fazio, X. (2015). Curricular critique of an environmental education policy: implications for practice. Brock Education: A Journal of Educational Research and Practice, 24(2), 88-108.

Kaya, N., Çobanoğlu, M. \& Artvinli, E. (2011). Sürdürülebilir kalkınma için Türkiye'de ve dünyada çevre eğitimi çalışmaları, ss. 407-417, 6. Ulusal Coğrafya Sempozyumu.

Kaygısız, Ü. (2012). Avrupa Birliği’nde son dönem demokratikleşme çabaları: Lizbon Antlaşmasının demokratikleşmeye katkısı. Süleyman Demirel Üniversitesi Vizyoner Dergisi, 3(1), 93-108.

Kaypak, Ş. (2013), Çevre Sorunlarının Çözümünde Küresel Çevre Politikaları. Muğla Üniversitesi Sosyal Bilimler Enstitüsü Dergisi, (31), 17-34.

Keleş, R. \& Hamamcı, C. (1998). Çevrebilim. (3. bs.). Ankara: İmge Kitabevi Yayınları.

Keleş, R. \& Hamamcı, C. (2002). Çevrebilim. (4. bs.). Ankara: İmge Kitabevi Yayınları.

Kesicioğlu, O. S. ve Alisinanoğlu, F. (2009). 60-72 aylık çocukların çevreye karşı tutumlarının çeşitli değişkenler açısından incelenmesi. Ahi Evran Üniversitesi Eğitim Fakültesi Dergisi, 10(3), 37-48.

Ketlhoilwe, M. J. (2007). Environmental education policy implementation challenges in Botswana schools. Southern African journal of environmental education, 24, 171-184.

Kılıç, S. (2001). Uluslararası çevre hukukunun gelişimi üzerine bir inceleme. Cumhuriyet Üniversitesi İktisadi ve İdari Bilimler Dergisi, 2(2), 131-149.

Kıvılcım, İ. (2014). İKV Değerlendirme Notu “AB’de 7. Çevre Eylem Programı Başladı”. İktisadi Kalkınma Vakfi, (82), 1-7.

Kızıl, M. (2012). Çevre bilimi dersinin fen bilgisi ögretmen adaylarının çevre bilgisi ve çevreye karşı tutumlarına olan etkisinin incelenmesi. [Yayımlanmamış Yüksek Lisans Tezi]. Niğde Üniversitesi Eğitim Bilimleri Enstitüsü.

Lavrysen, Luc, \& De Vos, N. (2002). Environmental law syllabus. Gent: Universiteit Gent.

Law, M. M. S., Hills, P. \& Hau, B. C. H. (2017). Engaging employees in sustainable development a case study of environmental education and awareness training in Hong Kong. Business Strategy and the Environment, 26(1), 84-97.

Lee, J. (1997). Environmental education in Hong Kong. Environmental Education Research, 3(3), 359-371.

Lee, J. C. \& Tilbury, D. (1998). Changing environments: the challenge for environmental education in China. Geography, 83(3), 227-236.

Lin, E. (2002). Trend of environmental education in canadian pre-service teacher education programs from 1979 to 1996. Canadian Journal of Environmental Education, 7(1), 199215.

Loubser, C. (2009). Establishing environmental education in the formal curriculum in South Africa: A Process of "Ebb and Flow". Taylor, N., Littledyke, M., Eames, C. \& Coll, R.K. (Ed.), Environmental Education in Context: An International Perspective on the Development of Environmental Education, p.179-184. Rotterdam/Boston/Taipei: Sense Publishers.

Makundi, E. (2003). Environmental Education Curriculum Policy in Tanzanian Schools. Southern African Journal of Environmental Education, 20, 135-141. 
1546 Ali Ekber Gülersoy - Hilal Yener - Tuğçe Turgut - Dilay Melis Özşahin - Deniz Anter...

McCrea, E. J. (2006). The roots of environmental education: how the past supports the future. Environmental Education and Training Partnership (EETAP). https://files.eric.ed.gov/fulltext/ED491084.pdf

McDuff, M. (2000). Thirty years of environmental education in Africa: The role of the Wildlife Clubs of Kenya. Environmental Education Research, 6(4), 383-396.

Mengi, A. \& Algan, N. (2003). Küreselleşme ve yerelleşme çă̆ında bölgesel sürdürülebilir gelişme: AB ve Türkiye örneği. Ankara: Siyasal Kitabevi.

Michelson, G. \& Ficher, D. (2017). Sustainability and education. In Hauff, M. V. \& Kuhnke, C. (Ed.), Sustainable Development Policy. A Europian Perpective, p. 135-158. London: Routledge.

Milli Eğitim Bakanlığ1 [MEB]. (2018). Biyoloji Dersi Öğretim Programı (Ortaokul 9.10.11.12. Sinıflar). Talim ve Terbiye Kurulu Başkanlığı, Ankara. http://mufredat.meb.gov.tr/ProgramDetay.aspx?PID=361

Milli Eğitim Bakanlığı [MEB]. (2018). Coğrafya Dersi Öğretim Programı (Ortaokul 9.10.11.12. Sinıflar). Talim ve Terbiye Kurulu Başkanlığı, Ankara. http://mufredat.meb.gov.tr/ProgramDetay.aspx?PID=336

Milli Eğitim Bakanlığı [MEB]. (2018). Fen Bilimleri Dersi Öğretim Programı (İlkokul ve Ortaokul 3.4.5.6.7.8. Sinıflar). Talim ve Terbiye Kurulu Başkanlığı, Ankara. http://mufredat.meb.gov.tr/ProgramDetay.aspx?PID=325

Milli Eğitim Bakanlığı [MEB]. (2018). Hayat Bilgisi Dersi Öğretim Programı (İlkokul 1,2 ve 3. Sinuflar). Talim ve Terbiye Kurulu Başkanlığı, Ankara. http://mufredat.meb.gov.tr/ProgramDetay.aspx?PID=326

Milli Eğitim Bakanlığı [MEB]. (2018). Kimya Dersi Öğretim Programı (Ortaokul 9.10.11.12. Sinıflar). Talim ve Terbiye Kurulu Başkanlığı, Ankara. http://mufredat.meb.gov.tr/ProgramDetay.aspx?PID=350

Milli Eğitim Bakanlığı. [MEB]. (2018). Sağllk Bilgisi ve Trafik Kültürü Dersi Öğretim Programı (Ortaokul 9. Sinıf). Talim ve Terbiye Kurulu Başkanlı̆̆ı, Ankara. http://mufredat.meb.gov.tr/ProgramDetay.aspx?PID=348

Miner, A. M., Malmsheimer, R. W., Keele, D. M., \& Mortimer, M. J. (2010). Twenty years of forest service national environmental policy act litigation. Environmental Practice, 12(2), 116-126.

Ministerio del Medio Ambiente. (MMA). (2011). Informe del Estado del Medio Ambiente 2011. República de Chile. Recuperado de: http://www..gob.cl/portal_2011/articles52016_InformeEsradoMedioAmbiente_Completo_ 2011 .pdf

Montanarella, L. (2015). Agricultural policy: Govern our soils. Nature News, 528(7580), 32.

Montero, J. M. (2004). El Medio en los medios. Actas del III Congreso Andaluz de Educación Ambiental, p. 154-157, Sevilla. Consejería de Medio Ambiente.

Muñoz-Pedreros, A. (2014). Environmental education in Chile, a task pending. Ambiente \& Sociedade, 17(3), 177-198.

National Curriculum Council (NCC). (1990). Cirruculum Guidenes 7: Environmental Education. New York: NCC. 
O’Donoghue, R. (1993). Clarifying environmental education: a search for clear action in Southern Africa. Southern African Journal of Environmental Education, 13, 28-38.

Obol, C., Allen, I. \& Bach, H. S. (2003). environmental education policy processes in the Southern African region, Southern African Journal of Environmental Education, 20, 22-38.

Okur, E. (2012). Sınıfdışı Deneyimsel Öğretim: Ekoloji Uygulaması. [Yayımlanmamış Doktora Tezi]. Çanakkale Onsekiz Mart Üniversitesi Eğitim Bilimleri Enstitüsü.

Ontario Ministry of Education (OME). (2009). Acting today, shaping tomorrow: A policy framework for environmental education in Ontario schools. Toronto: Queen's Printer for Ontario.

Orhan, G. (2013). Türkiye'de Çevre politikaları: değişen söylemler, değişmeyen öncelikler. Memleket Siyaset Yönetim Dergisi, (19-20), 1-24.

Ozaner, F. S. \& Yalçın, G. (2001). "Milli Parklarda Bilimsel Çevre Eğitimi”, V. Uluslararası Ekoloji ve Çevre Sorunları Sempozyumu, ss. 64-76, Ankara Alman Kültür Merkezi.

Ozmehmet, D. (2008). Dünya'da ve Türkiye'de sürdürülebilir kalkınma yaklaşımları. Journal of Yaşar University, 3(12), 1853-1876.

Ökmen, M. (2000). Çevre sorunlarının sistemler-üstü niteliği ve Orta Asya. Bilig, (14), 17-29.

Ökmen, M. (2004). Politika ve Çevre. Marin, M. C. ve Yıldırım U. (Eds.), Çevre Sorunlarına Çağdaş Yaklaşımlar, ss. 327-368. İstanbul: Beta Basım Yayım Dağıtım.

Öner, F. \& Arslan, M. (2005) Çevre bilincinin gelişimi, okullarımızda etkili çevre eğitimi ve gelişmiş bazı ülkelerden örnekler. Çoksevim, B. ve Ceyhan, O. (Der.), I. Ulusal Erciyes Sempozyumu Bildiriler Kitabl, 23-25 Ekim 2003, ss. 252-263. Kayseri: Kayseri Valiliği Çevre Koruma Vakfi.

Özbuğutu, E., Karahan, S. \& Tan, Ç. (2014). Çevre eğitimi ve alternatif yöntemler-literatür taramas1/environmental education and its alternative methods-a literature review. Mustafa Kemal Üniversitesi Sosyal Bilimler Enstitüsü Dergisi, 11(25), 393-408.

Özdemir, A. (2017). Bütün öğrencilerin okulu finlandiya okulları. Informal Ortamlarda Araştırmalar Dergisi, 2(1), 59-91.

Özdemir, O. (2007). Yeni bir çevre eğitimi perspektifi: "Sürdürülebilir gelişme amaçlı eğitim". Eğitim ve Bilim, 32(145), 23-38.

Özkan, Ö., Tekkaya, C. \& Geban, Ö. (2001). Ekoloji Konularındaki Kavram Yanılgılarının Kavramsal Değişim Metinleri İle Giderilmesi. Yeni Bin Yılın Başında Fen Bilimleri Eğitimi Sempozyumu Bildiriler Kitabl, ss. 191-194. İstanbul.

Özoğul, S. Ç. (1993). "Yaygın eğitim düzeyinde çevre için eğitim”, ss. 65-80, Ankara: Çevre Eğitimi, Türkiye Çevre Vakfı Yayınları.

Özsoy, T. (2011). Tüketimin sürdürülebilirliği: ürün ömrüne yönelik tüketici tutum ve davranışları üzerine bir araştırma. [Yayımlanmamış Doktora Tezi]. Çukurova Üniversitesi Sosyal Bilimler Enstitüsü.

Öztürk, F., Özcan, A. F., Çimen, S., Özkan, A. \& Balkaş, S. R. (2016), Değerler eğitimine yönelik kültürler arası karşılaştırmalı bir araştırma: Almanya, İsveç, Güney Kore ve Malezya örneği, Akademik Sosyal Araştırmalar Dergisi, 30, 629-649.

Öztürk, E. \& Erten, S. (2020). Uluslararası bir çevre eğitimi programı olan Yeşil Kutu Projesinin fen bilgisi öğretmen adaylarının çevreye yönelik tutumu, çevre bilgisi ve çevre dostu 
1548 Ali Ekber Gülersoy - Hilal Yener - Tuğçe Turgut - Dilay Melis Özşahin - Deniz Anter...

davranışlarına etkisi. Eskişehir Osmangazi Üniversitesi Türk Dünyası Uygulama ve Araştırma Merkezi Eğitim Dergisi, 5 (2), 145-166.

Pace, P. (2010). Education for sustainable development: current fad or renewed commitment to action. Journal of Baltic Science Education, 9(4), 315-323.

Pagelio, J. (2002). Theoretical perspectives on national identity. In Proceedings of the national seminar. On promoting national identity through education, p. 17-23, Waigani, Papua New Guinea, National Department of Education.

Phiri, G. R. (2009). Prospects for and constraints to effective implementation of environmental education in Malawi. Taylor, N., Littledyke, M., Eames, C. and Coll, R.K. (Ed.), Environmental Education in Context: An International Perspective on the Development of Environmental Education, p. 195-202. Rotterdam/Boston/Taipei: Sense Publishers.

Popeanga, V. (2013). Environmental action programmes in the european union-evolution and specific. University of Targu Jiu Letter and Social Science Series, No: 3, 24-33.

Porto Gonçalves, C. W. (2006). El desafio ambiental. Programa de las Naciones Unidas para el Medio Ambiente. México: Oficina Regional para América Latina y el Caribe.

Ravensbergen, S. (2012). Outstanding environmental education programs in North America. [Yayımlanmamış Araştırma]. University of British Colombia, Vancouver, BC.

Rioux, J. C. (1973). Environmental education in primary and secondary schools in Canada. Ottawa: Environment Canada.

Robottom, I. (2003). Avustralia. In Environmental Education In 21th Century. Palmer, J.A (Ed.). New York: Routledge.

Rome, A. (2010). The genius of earth day. Environmental History, 15(2), 194-205.

Ryan, A. (2009). Environmental education in context, an international perspective on the development of environmental education, p. 9-17. Rotterdam: Boston Sense Publishers.

Sahlberg, P. (2007), Education policies for raising student learning: the finnish approach. Journal of education policy, 22(2), 147-171.

Sarıçoban, K. \& Yıldırımcı, E. (2015). Çevre politikaları bağlamında sürdürülebilir kalkınma ve çevresel harcamalar: ab üyesi ülkeler ile bir karşılaştırma. ASSAM uluslararası Hakemli Dergi, (3), 7-24.

Sarıkaya, H. Z. (2004). Avrupa Birliği uyum sürecinde çevre politikaları ve uygulamaları. Su Kirlenmesi Kontrolü Dergisi, 14(1), 1-10.

Sauvé, L. (1996). Environmental education and sustainable development: A further appraisal. Canadian Journal of Environmental Education, 1, 7-34.

Sustainable Development Knowledge Partnership (SDKP). (2021). Description/achievement of initiative. https://sustainabledevelopment.un.org/partnership/?p=1635

Seybold, H. \& Rieß, W. (2006). Research in Environmental Education And Education For Sustainable Development İn Germany: The State Of The Art. Environmental Education Research, 12(1), 47-63.

Shutaleva, A., Nikonova, Z., Savchenko, I. \& Martyushev, N. (2020). Environmental education for sustainable development in Russia. Sustainability, 12(18), 7742.

Smyth, J. (1999). Is there a future for education consistent with Agenda 21?. Canadian Journal of Environmental Education (CJEE), 4(1), 69-82. 
Soltys, D. \& Orynbassarova, D. (2013). Delivering environmental education in Kazakhstan through civic action: second-wave values and governmental responses. Environmental Values, 22(1), 101-122.

Soykan, A., Atasoy, E., \& Kostova, Z. (2012), Historical Development of Environmental Education in Bulgaria. Journal of Environmental Biology, 33(2), 499-508.

Squella, M. P. (2000). La educación ambiental en Chile. Un estudio exploratorio. Hamburg, Münster, Alemania: Editorial LIT Verlag Berlín.

State Environmental Protection Bureau Propaganda and Education (Ed.). (1991). Theory and Practice of Environmental Education in China (1985-1990).

Stokes, E., Edge, A., \& West, A. (2001). Environmental educaion in the educational systems of the European Union: Synthesis report. London School of Economics and Political Science, Centre for Educational Research.

Sungurtekin, S. (2001). Uygulamalı çevre eğitimi projesi kapsamında ana ve ilköğretim okullarında müzik yoluyla çevre eğitimi. Uludağ Üniversitesi Eğitim Fakültesi Dergisi, 14(1), 167178.

Şafak, Ş. \& Erkal, S. (1999), Çevre eğitimi ve aile. Eğitim ve Bilim, 23(112), 63-66

Şahin, N. F., Cerrah, L., Saka, A. \& Şahin, B. (2004). Yükseköğretimde öğrenci merkezli çevre eğitimi dersine yönelik bir uygulama. Gazi Üniversitesi Gazi Eğitim Fakültesi Dergisi, 24(3), 113-128.

T. C. Cumhurbaşkanlığı Strateji ve Bütçe Başkanlığı. (SBB). (2019). On Birinci Kalkınma Planı (2019- 2023). Ankara.

T.C. Başbakanlık Devlet Planlama Teşkilatı Müsteşarlığı. (DPT). (1979). Dördüncü beş yıllık kalkınma planı (1979-1983). Ankara.

T.C. Başbakanlık Devlet Planlama Teşkilatı Müsteşarlığı. (DPT). (1984). Beşinci beş yıllık kalkınma planı (1985-1989). Ankara.

T.C. Başbakanlık Devlet Planlama Teşkilatı Müsteşarlığı. (DPT). (1989). Altıncı beş yıllık kalkinma planı (1990-1994). Ankara.

T.C. Başbakanlık Devlet Planlama Teşkilatı Müsteşarlığı. (DPT). (1995). Yedinci beş yıllık kalkınma planı (1996-2000). Ankara.

T.C. Başbakanlık Devlet Planlama Teşkilatı Müsteşarlığı. (DPT). (2000). Uzun vadeli strateji ve sekizinci beş yıllık kalkınma planı (2001-2005). Ankara.

T.C. Başbakanlık Devlet Planlama Teşkilatı Müsteşarlı̆̆ı. (DPT). (2006). Dokuzuncu kalkınma planı (2007-2013). Ankara.

T.C. Dışişleri Bakanlığı Avrupa Birliği Başkanlığı (2021). Fasıl 27: Çevre ve İklim Değişikliği Avrupa Birliği'nin Çevre ve İklim Değişikliği Politikası. https://www.ab.gov.tr/fasil-27cevre_92.html

T.C. Kalkınma Bakanlığı. (2013). Onuncu Kalkınma Planı (2014-2018). Ankara.

Tanrıverdi, B. (2009). Sürdürülebilir çevre eğitimi açısından ilköğretim programlarının değerlendirilmesi. Ĕgitim ve Bilim, 34(151), 89-103.

Tepebaş, U. (2009). 1990 sonrası Afrika:" Mücadele alanı". [Yayımlanmamış Yüksek Lisans Tezi]. Kadir Has Üniversitesi, Sosyal Bilimler Enstitüsü. 
1550 Ali Ekber Gülersoy - Hilal Yener - Tuğçe Turgut - Dilay Melis Özşahin - Deniz Anter..

Terzi, S. (2017). Sürdürülebilir kalkınma çerçevesinde Türkiye'de uygulanan çevre politikası araçlarının değerlendirilmesi. [Uzmanlık Tezi]. T.C. Çevre ve Şehircilik Bakanlığı: Ankara.

Tian, Y. \& Wang, C. (2016). Environmental education in China: development, difficulties and recommendations. Journal of social science studies, 3(1), 31-43.

Toprak, Z. (2003). Çevre yönetimi ve politikası. İzmir: Anadolu Matbaacılık.

Torunoğlu, E. (2018). Ulusal çevre koruma politikaları. Öğütveren, Ü. B. (Der.), Çevre sorunları ve politikaları içinde. ss. 112-129. Eskişehir: Anadolu Üniversitesi Açık Öğretim Fakültesi Yayın1.

Tsebelis, G. \& Kalandrakis, A. (1999). The European Parliament and Environmental Legislation: The Case of Chemicals. European Journal of Political Research, 36, 119-154.

Türk, B. \& Erciş, A. (2017). Türkiye'de çevre politikası ve uluslararası çevre sözleşmeleri. The Journal of Academic Social Science Studies, 54, 351-392.

Türkiye Büyük Millet Meclisi. (TBMM). (2015). T.C. 1982 Anayasasl. https://www.tbmm.gov.tr/anayasa.htm

Türkiye Cumhuriyeti Yüksek Öğretim Kurumu (YÖK). (2018). Okul Öncesi Öğretmenliği Lisans Programı. https://www.yok.gov.tr/kurumsal/idari-birimler/egitim-ogretim-dairesi/yeniogretmen-yetistirme-lisans-programlari

Türkiye Çevre Vakfı (TÇV). (2001). Avrupa Birliği'nde ve Türkiye'de çevre mevzuatı. Ankara: Türkiye Çevre Vakfı Yayınları.

Ulucak, R. \& Erdem, E, (2012). Çevre-iktisat ilişkisi ve Türkiye'de çevre politikalarının etkinliği. Akademik Araştırmalar ve Çalışmalar Dergisi (AKAD), 4(6), 78-98.

Ulukent, A. N. (2010). Avrupa Birliği çevre politikaları ve Türkiye. [Yayımlanmamış Yüksek Lisans Tezi]. Trakya Üniversitesi Sosyal Bilimler Enstitüsü.

UNESCO-UNEP-IEEP (1992). Changing minds - Earthwise", a selection of articles from Connect. Newsletter. Paris: UNESCO.

UNESCO-UNEP (1978). The Tbilisi declaration. Connect. UNESCO-UNEP Environmental Education Newsletter. Paris: UNESCO.

UNESCO (1992). UN Conference on environment and development: Agenda 21. Switzerland: UNESCO.

UNESCO (1997). Educating for a sustainable future: a transdisciplinary vision for concerted Action International Conference. Paris: UNESCO.

UNESCO (2005a). Guidelines and recommendations for reorienting teacher education to address Sustainability. UNITWIN/UNESCO Chair For Reorienting Teacher Education To Address Sustainability. York University, Toronto and the International Netwoek Of teacherEducation Institutions.

UNESCO (2005b). Report by the Director-General on the United Nations Decade of Education for Sustainable Development: International Implementation Scheme and UNESCO'S Contribution to the Implementation of the Decade. Paris: UNESCO.

UNESCO (2009). Report by the Director-General on the UNESCO World Conference on Education for Sustainable Development and the Bonn Declaration. Paris: UNESCO. 
UNESCO Türkiye Milli Komisyonu (2018). Sürdürülebilir Kalkınma 2030 Hedefleri Ihtisas Komitesi.

https://www.unesco.org.tr/Pages/108/219/S\%C3\%BCrd\%C3\%BCr\%C3\%BClebilirKalk\%C4\%B1nma-2030-Hedefleri-\%C4\%B0htisas-Komitesi

UNEVOC (2007). 4th Intl. Conference on Environmental Education, https://unevoc.unesco.org/home/4th+International+Conference+on+Environmental+Educat ion+in +Ahmedabad,+India

United Nations Conference on Environment and Development (UNCED). (1992). Agenda 21, the United Nations Programme of Action from Rio. New York: UN Department of Public Information.

United Nations Environment Programme Agency (UNEP) and World Meteorological Organization (WMO). (2010). Scientific Assessment of Ozone Depletion 2010 Report. http://www.unep.org/Documents.Multilingual/Default.Print.asp?DocumentID=647andArtic leID $=6751$ andl=enandt=long

Ünal, S. \& Dımışkı, E. (1998). Unesco uluslararası çevre eğitim programına (IEEP) göre ortaöğretim çevre eğitimi için öğretmenlerin yetiştirilmesi. M. Ü. Atatürk Ĕ̈itim Fakültesi Ĕ̈itim Bilimleri Dergisi, 10, 299-308.

Ünal, S. \& Dımışk1, E. (1999). UNESCO-UNEP himayesinde çevre eğitiminin gelişimi ve türkiye'de ortaöğretim çevre eğitimi. Hacettepe Üniversitesi Ĕ̆itim Fakültesi Dergisi, (1617), 142-154.

Viteri, F., Clarebout, G. \& Crauwels, M. (2013). Environmental education in ecuador: conceptions and currents in quito's private elementary schools. Environmental Education Research, 19(5), 577-599.

Webb, P. \& Boltt, G.(1990). Food chain to food web: a natural progression?. Journal of Biological Education, 24(3), 187-191.

Winfield, M. \& Jenish, G. (1999). Ontario's environment and the common sense revolution: A four year report. Canada: Canadian Institute for Environmental Law and Policy.

Xiaoyun, L. \& Qiang, D. (2010). China's environmental education. Chinese Education \& Society, 43(2), 6-15.

Yaman, K. \& Gül, M. (2018). Kuruluşundan günümüze Avrupa Birliği’nin çevre politikası. Ekonomi İ̧letme ve Yönetim Dergisi, 2(2), 198-217.

Yıldız, K., Sipahioğlu, Ş. \& Yılmaz, M. (2005). Çevre Bilimi (2. Bs.), Ankara: Gündüz Eğitim ve Yayıncilik.

Yurdakul Erol, S. (2012). Çevre politakası aracı olarak eğitim ve bilinçlendirme çalışmaları ve Akdeniz bölgesi için işlevsel önemi. Kahramanmaraş Sütçü İmam Üniversitesi Dergisi, Özel Sayı, 185-192.

Yücel, S. A. \& Morgil, F. İ. (1998). Yükseköğretimde çevre olgusunun araştırılması. Hacettepe Üniversitesi Eğitim Fakültesi Dergisi, (14), 84-91.

Yüksel, Y. (2020). Sertifikasız okullar ile eko-okullar ve yeşil bayraklı eko-okulların sürdürülebilirlik bilinci açısından karşılaştırılması. Dicle Üniversitesi Ziya Gökalp Eğitim Fakültesi Dergisi, (36), 50-62.

Zengin, E. (2008). Çevre sorunlarının önlenmesinde önemli bir faktör olarak çevre eğitimi. Bakı Dövlat Universiteti Illahiyyat Fakültasinin Elmi Macmuasi, 9, 229-243. 
1552 Ali Ekber Gülersoy - Hilal Yener - Tuğçe Turgut - Dilay Melis Özşahin - Deniz Anter...

Zhou, X., Liu, Z., Han, C. \& Wang, G. (2016). Early childhood education for sustainable development in China. In Siraj-Blatchford, J., Mogharreban, C., Park, E. (Ed.) International Research on Education for Sustanable Development in Early Childhood. Cham: Springer.

\section{Beyan ve Açılamalar (Disclosure Statements)}

1. Araştırmacıların katkı oranı beyanı / Contribution rate statement of researchers:

1. Yazar/First author \%20

2. Yazar/Second author $\% 20$

3. Yazar/Third author $\% 20$

4. Yazar/Fourth author $\% 20$

5. Yazar/Fifth author $\% 20$

2. Yazarlar tarafından herhangi bir çıkar çatışması beyan edilmemiş̧ir (No potential conflict of interest was reported by the authors). 